\title{
Evaluating Models for Cretaceous Paleodrainage and Sediment Routing using Detrital Zircon U-Pb Provenance and Geochronology in the Colorado Front Range
}

\author{
By \\ Caroline Mary Nazworth \\ B.S., The University of Texas at Austin, 2017 \\ Submitted to the graduate degree program in the Department of Geology and the Graduate \\ Faculty of the University of Kansas in partial fulfillment of the requirements \\ for the degree of Master of Science.
}

Chair: Dr. Mike Blum

Dr. Stephen Hasiotis

Dr. Greg Ludvigson

Dr. Noah McLean

Date Defended: 20 November 2019 
The thesis committee for Caroline Mary Nazworth certifies that this is the approved version of the following thesis:

\section{Evaluating Models for Cretaceous Paleodrainage and Sediment Routing using Detrital Zircon U-Pb Provenance and Geochronology in the Colorado Front Range}

Chair: Dr. Mike Blum

Date Approved: 20 November 2019 


\begin{abstract}
The Late Jurassic Morrison Formation through the Aptian to Cenomanian Dakota Group is a succession of fluvial, deltaic, and shallow-marine strata deposited within the back-bulge of the Mesozoic Sevier retroarc foreland-basin system, now located in the present-day Colorado Front Range and US midcontinent. Multiple sediment-routing models have been proposed for North American paleodrainage during this time period. This study investigates the Late Jurassic through Campanian Morrison, Lytle, Plainview, and Dakota succession with the following objectives: (a) examine river system scale and fluvial style differences from alluvial architectures; (b) test previous paleodrainage models through detrital zircon (DZ) U-Pb geochronology and provenance and present a new reconstruction of sediment-dispersal patterns; and (c) develop the geochronological framework using DZ U-Pb maximum depositional ages
\end{abstract} (MDAs) that approximate true depositional age (TDA).

Comparison of alluvial architectures and sedimentological characteristics from sites along the Colorado Front Range result in observed differences in fluvial styles represented by the Morrison, Lytle, Plainview, and Dakota formations. The Morrison Formation is interpreted to have been deposited by a net aggradational meandering fluvial system; the Lytle Formation is interpreted to represent a mixed bedrock-alluvial valley system, where the river is inherently degradational and confined within a broad incised valley; the Plainview Formation is interpreted to consist of mixed fluvial and near shore marine deposits, aggrading within the Lytle bedrock valleys; and the upper Dakota Formation is interpreted to represent a fluvial system that cut across delta plains represented by the lower Dakota during regression.

Statistical analysis of DZ U-Pb populations of 22 samples collected for this study indicate clear differences between the interpreted west-derived Cretaceous Lytle and Dakota signatures of 
the Colorado Front Range, southwestern Kansas, and the Black Hills of South Dakota and the interpreted east-derived Dakota signatures of the further eastern US midcontinent in Kansas, Nebraska, and South Dakota. West-derived samples have DZ U-Pb signatures with Western Cordilleran magmatic arc grains present, which are distinctly absent in east-derived samples. Moreover, east-derived DZ U-Pb signatures are dominated by primary Appalachian-Grenville populations from the Appalachian-Ouachita Cordillera, whereas west-derived signatures are dominated by recycled Appalachian-Grenville populations from the Sevier fold and thrust belt, along with contributions from the Western Cordilleran magmatic arc, Mid-Continent, and Yavapai-Mazatzal source terrains. Mixing models and statistical comparisons were used to provide a new paleodrainage model that features convergence of east- and west-derived systems in the US midcontinent, which then flow north toward the Western Canada Sedimentary Basin and Boreal Sea. This fluvial system is interpreted as the south-to-north oriented axial system that deposited the Early Cretaceous McMurray Formation of the Alberta Oil Sands.

DZ samples from the Late Jurassic Morrison Formation in Colorado produced MDAs that are slightly younger than ages previously published from sanidine grains in bentonites from Utah. These new MDAs indicate that Morrison deposition continued for another 1-2 Myrs longer than previously thought. DZ samples from the Early Cretaceous Lytle and age-equivalent formations did not produce multiple young volcanogenic grains to enable MDA calculation due to deposition during the Early Cretaceous magmatic lull. DZ samples from the Albian to Cenomanian Dakota Formation produced the first U-Pb ages for the Dakota in Colorado and MDAs consistent with published age estimates. 


\section{Acknowledgements}

First, I thank my advisor, Dr. Mike Blum, for the opportunity to work with him at the University of Kansas and for his guidance, support, and time. I would also like to thank my committee members Dr. Greg Ludvigson, Dr. Noah McLean, and Dr. Steve Hasiotis for their feedback and insight. I am also appreciative of Dr. Diane Kamola and Dr. Jen Roberts for the support and mentorship they have provided during my time at KU.

I am very grateful for the financial support provided by the Roscoe G. Jackson III and Chevron Graduate Fellowships. This project greatly benefitted from funding provided by the KU Department of Geology, the Michael S. Johnson Scholarship from the Rocky Mountain Association of Geologists, a Geological Society of America Graduate Student Research Grant, a Colorado Scientific Society Research Grant, a Kansas Geological Society Scholarship, and an Association of Earth Science Clubs of Greater Kansas City Scholarship. I would also like to thank ExxonMobil and the Arizona Laserchron Center for their roles in financing sample collection and data processing, and Wade Leibach for assisting me in the field.

Most of all, I thank my parents, Laurine and Bryan, for their support of my education and the confidence they have had in me since the beginning. Finally, a big thank you to my husband, Ethan, for being there every step of the way and for listening to me talk about rocks. 


\section{Table of Contents}

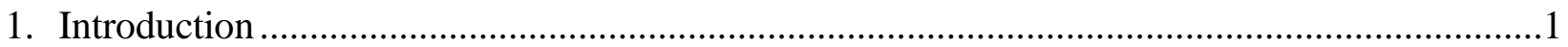

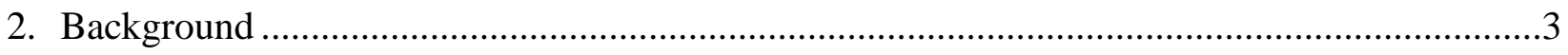

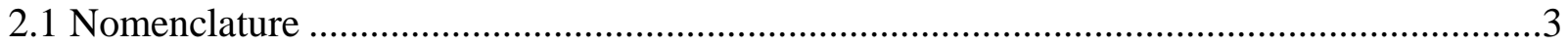

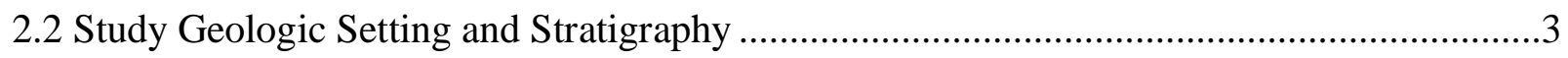

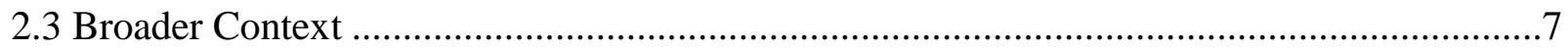

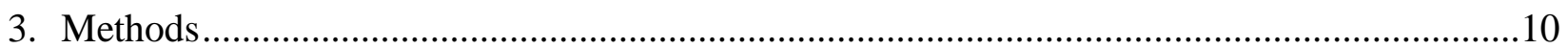

3.1 Field Methodology and Measured Sections ........................................................ 10

3.2 Detrital Zircon U-Pb Dating and Statistical Analysis .............................................11

3.3 Detrital Zircon U-Pb Analytical Methods ................................................................12

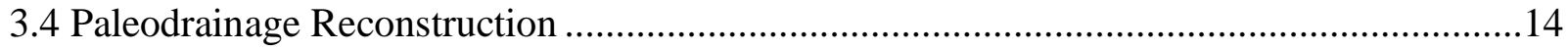

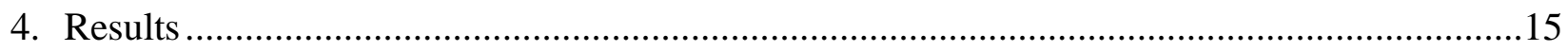

4.1 Alluvial Architecture and Sedimentological Observations ..........................................15

4.2 Detrital Zircon U-Pb Age Populations ................................................................ 17

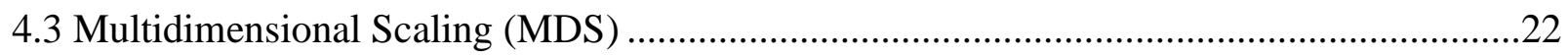

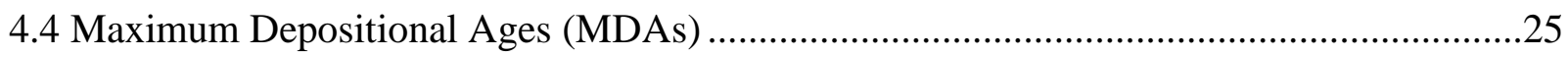

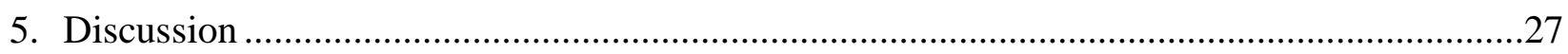

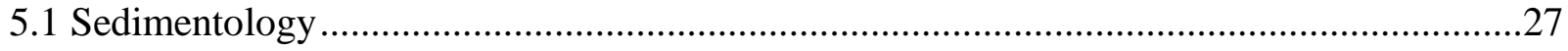

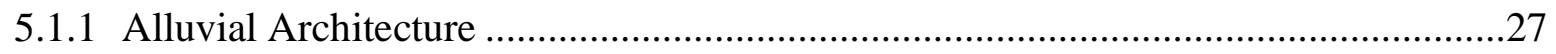

5.1.2 Fluvial System Scales ........................................................................ 30

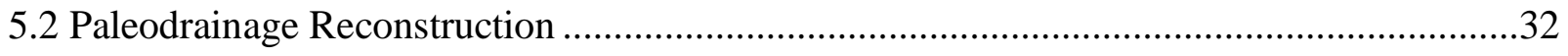

5.2.1 Morrison Formation Paleodrainage ..............................................................32

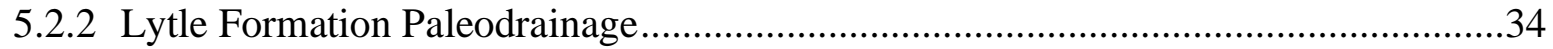


5.2.3 Dakota Formation Paleodrainage ................................................................................

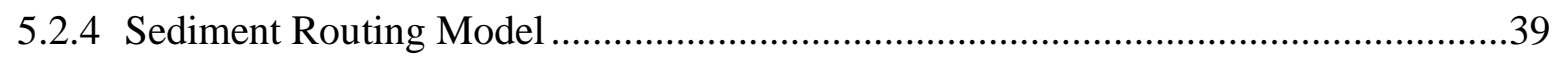

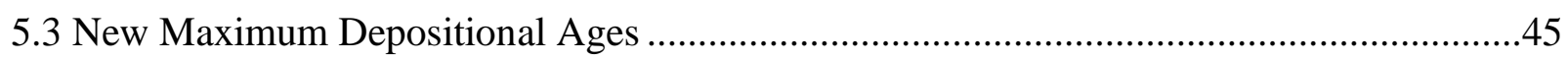

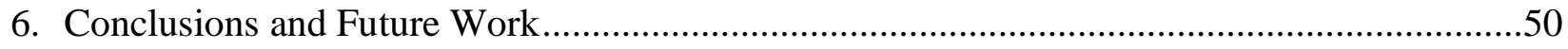

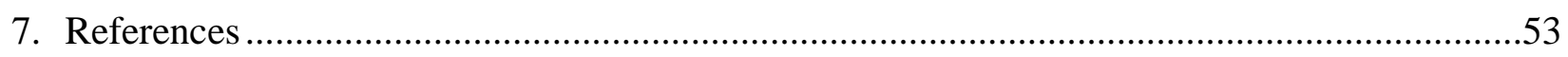

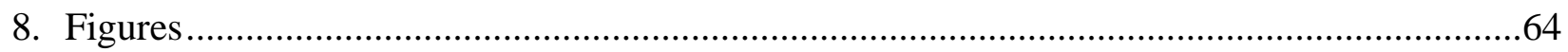

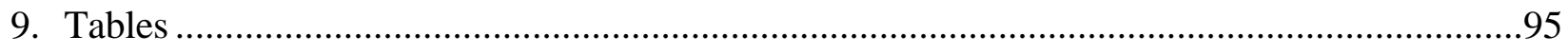

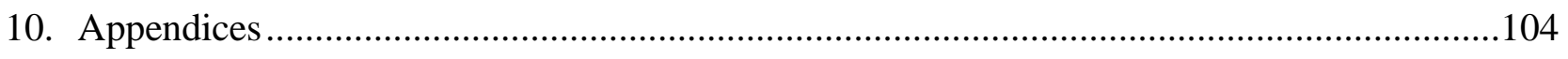

Appendix A: Measured sections ...................................................................................104

Appendix B: Arizona LaserChron Center analytical methods ................................................120

Appendix C: DZ U-Pb dataset ..................................................................................122

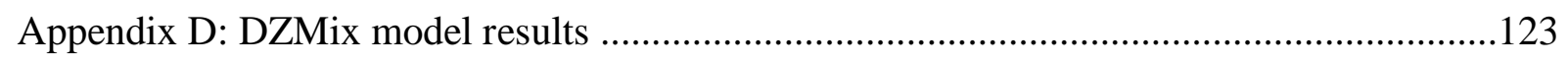




\section{List of Figures}

Figure 1. Blum and Pecha (2014) paleodrainage model 64

Figure 2. Benyon et al. (2016) paleodrainage model 65

Figure 3. Map of sample locations 66

Figure 4. Primary detrital zircon source terrains in North America 67

$\begin{array}{lll}\text { Figure 5. Apparent infusive flux rates over the past } 200 \mathrm{Ma} & 68\end{array}$

Figure 6. Idealized composite stratigraphic section for the Colorado Front 69 Range deposits

Figure 7. Average percentage of each age population for all 22 samples 70

Figure 8. Normalized kernel density estimates of Morrison Formation samples 71

Figure 9. Normalized kernel density estimates of Lytle Formation (and 72 equivalent) samples

Figure 10. Normalized kernel density estimates of Dakota Formation samples 73

Figure 11. Average percentage of each age population and location for Morrison 74 Formation samples

Figure 12. Average percentage of each age population and location for Lytle Formation (and equivalent) samples

Figure 13. Average percentage of each age population and location for Dakota Formation samples

Figure 14. Normalized kernel density estimates of grains <275 Ma for all samples 77

Figure 15. Normalized kernel density estimates of grains 800-1800 Ma for all 78 samples

Figure 16. Multidimensional scaling plots of Morrison, Lytle (and equivalent), and Dakota samples

Figure 17. Maximum depositional ages of Morrison Formation samples

Figure 18. Maximum depositional ages of Dakota Formation samples 81

Figure 19. Normalized kernel density estimates of Dakota Formation samples, 82 including a second curve with all grains $>275 \mathrm{Ma}$

Figure 20. Examples of fluvial styles represented in the Morrison, Lytle, Plainview, and Dakota formations from the Colorado Front Range 
Figure 21. North-to-south transect of Colorado Front Range measured sections

Figure 22. Paleodrainage reconstruction of Morrison fluvial systems

Figure 23. Paleodrainage reconstruction of Lytle (and equivalent) fluvial systems

Figure 24 Paleodrainage reconstruction of Dakota fluvial systems

Figure 25. Interpreted map of Kansas basal Cretaceous valleys and paleoflow 88

Figure 26. Multidimensional scaling plot of Lytle (and equivalent) and McMurray samples

Figure 27. Multidimensional scaling plot of west-derived Lytle (and equivalent), 89 McMurray, and east-derived Dakota samples

Figure 28. General Early Cretaceous sediment routing model 90

Figure 29. Relative contributions of parent samples for DBK-06 from the Kuiper 91 V statistic

Figure 30. Relative contributions of parent samples for DBK-06 from the KS D statistic

Figure 31. Relative contributions of parent samples for DBK-11 from the Kuiper V statistic

Figure 32. Relative contributions of parent samples for DBK-11 from the KS D statistic 


\section{List of Tables}

Table 1. Summary of Early Cretaceous Colorado Front Range nomenclature 95

Table 2. Original source and potential recycled locations of $\mathrm{DZ} \mathrm{U-Pb}$ age 96 populations in this study

$\begin{array}{lll}\text { Table 3. } & \text { DBK sample locations } & 98\end{array}$

Table 4. Summary of youngest grains and maximum depositional ages 99 calculated for each sample using DZ U-Pb data

Table 5. Measurements of unit thickness 101

Table 6. Measurements of thicknesses and internal dip angles of inclined-strata 101 sets

Table 7. Measurements of mean cross-bed thicknesses with calculated mean 102 bedform height and river flow depth

Table 8. Relative contributions for DBK-06 from the Kuiper V statistic, KS D 103 statistic, and the mean

Table 9. Relative contributions for DBK-11 from the Kuiper V statistic, KS D 103 statistic, and the mean 


\section{Introduction}

Provenance and sediment routing is a primary interest in source-to-sink analysis of sediment-dispersal systems and interpretation of the stratigraphic record. Detrital zircon $\mathrm{U}-\mathrm{Pb}$ (hereafter $\mathrm{DZ} \mathrm{U}-\mathrm{Pb}$ ) provenance and geochronological techniques represent proven methods for identifying source terrains and the broad patterns of sediment routing through identification of the ultimate and recycled sources of DZ U-Pb age populations (Riggs et al., 1996; Fedo et al., 2003; Dickinson and Gehrels, 2009; Gehrels, 2012). This powerful tool can therefore provide support for, or falsify, ancient sediment-routing patterns inferred using more traditional provenance data, as well as provide maximum depositional ages (MDAs) of units, which can facilitate regional correlations and calculation of deposition rates.

The Late Jurassic Morrison Formation and the Aptian to Cenomanian Dakota Group of the Colorado Front Range are generally known to represent fluvial, deltaic, and shallow-marine strata deposited in the Mesozoic "Sevier" retroarc foreland basin of the US western interior. Previous research has described and characterized these units in terms of their environments of deposition (Waagé, 1955; Weimer, 1970; Gustason and Kauffman, 1985; Dolson and Weimer, 1992; Holbrook and Ethridge, 1996) and shown they have paleocurrent indicators that suggest general west-to-east sediment transport. However, most older studies predate the widespread use of $\mathrm{DZ} \mathrm{U-Pb}$ data, were conducted with different goals in mind, and/or have not been interpreted within larger tectonic and geodynamic contexts.

This study originated as an ExxonMobil Upstream Research Company (EMURC) initiative in 2013 to test an internal company model for Early Cretaceous paleodrainage, which was published in Blum and Pecha (2014). Recent work has suggested that fluvial deposits of the Morrison Formation and especially the Dakota Group, including age-equivalent strata in the 
midcontinent, represent part of a continental-scale fluvial system that routed sediment to the north and the Boreal Sea (Raines et al., 2013; Blum and Pecha, 2014), or has suggested alternative models for sediment routing during this time period (e.g. Benyon et al., 2014; 2016; Quinn et al., 2018). This study examines the Morrison Formation and Dakota Group in the Colorado Front Range with the following objectives in mind: (a) characterize and contrast the alluvial architectures of each unit to examine the scale of river systems and differences in fluvial styles; (b) analyze a large dataset of $\mathrm{DZ} \mathrm{U-Pb}$ ages to test previous models and present a detailed reconstruction of paleodrainage and sediment-dispersal patterns; and (c) improve the geochronological framework for the Morrison Formation and Dakota Group using DZ U-Pb MDAs. Moreover, existing DZ U-Pb ages from samples of the Dakota Group in South Dakota, Nebraska, and Kansas are used in this study to further constrain provenance of fluvial deposits in the US midcontinent and how they add to our understanding of Cretaceous sediment routing. 


\section{Background}

\subsection{Nomenclature}

There is little confusion of nomenclature for the Late Jurassic Morrison Formation, but Cretaceous deposits of the Rocky Mountain and midcontinent regions have been referred to by a variety of names (Carpenter, 2014) (Table 1). Early research (e.g. Waagé, 1953; 1955; McLaughlin, 1954; MacKenzie, 1963; 1965; 1971; Weimer, 1970) established differing terminologies dependent on the area being studied and what they considered to be important in terms of variability between units. As used herein, basal Cretaceous sandstones that rest unconformably on Jurassic Morrison and older strata in the Colorado Front Range are referred to as the Lytle Formation: stratigraphically equivalent basal Cretaceous strata are referred to as the Cheyenne Sandstone in southwestern Kansas and the Cloverly or Lakota Formations in Wyoming or the Black Hills of South Dakota, respectively (Moore et al., 1951; McLaughlin, 1954; Waagé, 1955; Moberly, 1960; Bolyard and McGregor, 1966). In the Front Range, the Lytle is overlain by the Plainview Formation, followed by the Kiowa-Skull Creek Shale, and the sand-rich Dakota Formation. The Fall River Sandstone is the Plainview equivalent in the Black Hills of South Dakota: here and to the east in the midcontinent, Lytle, Plainview, and their equivalents are overlain by the Skull Creek Shale and Dakota Group sandstones.

\subsection{Study Geologic Setting and Stratigraphy}

The Morrison Formation and Dakota Group of the Colorado Front Range were deposited within the eastward-migrating Sevier retroarc foreland-basin system. This basin formed due to westward migration of the North American plate, subduction of the Farallon plate, development of the Western Cordilleran magmatic arc, and development of the Sevier fold and thrust belt 
(hereafter SFTB) (Burchfiel and Davis, 1975; Kauffman and Caldwell, 1993; Pang and Nummedal, 1995; DeCelles and Currie, 1996; DeCelles, 2004; Liu et al., 2011). Cordilleran orogenesis and the Sevier foreland-basin system remained active from the Middle Jurassic to the Late Cretaceous (DeCelles, 2004), after which development of Laramide structures partitioned the Western Interior Basin (Brown, 1998; Erslev, 1993; DeCelles, 2004, Heller and Liu, 2016). Based on reconstructions of foreland basin evolution through time, the Morrison Formation through Dakota Group of the Colorado Front Range and Great Plains were most likely deposited in the broad back-bulge depozone, 800 to $1200 \mathrm{~km}$ from the active orogenic front (DeCelles, 2004). Eastward migration of the forebulge and dynamic uplift are proposed to be responsible for the basal Cretaceous unconformity (DeCelles and Currie, 1996; Currie, 1998).

Morrison strata have been well studied throughout Utah and Colorado, including near Golden and Morrison, Colorado, which is the type area (Peterson and Turner, 1998), and are interpreted to represent fluvial, lacustrine, and floodplain environments of deposition. There are no firm geochronological controls for the Morrison in the Front Range, but equivalent strata in Utah are assumed to be mid-Kimmeridgian to mid-Tithonian in age (ca. 150-157 Ma) based on 40Ar/39Ar dating of sanidine grains from bentonites in Utah (Kowallis et al., 1998; Trujillo and Kowallis, 2015).

Lytle strata rest unconformably on and erosionally truncate the Morrison Formation in Colorado with the contact argued to represent a 20 Myr time gap (DeCelles and Currie, 1996): the Lytle is interpreted to represent deposition by fluvial channels confined within an incised valley (Waagé, 1955; Weimer, 1970; Holbrook and Ethridge, 1996). The Lytle and ageequivalent strata in the midcontinent are interpreted to be Barremian to Aptian in age (May et al., 1995). Zircons obtained from Lower Cretaceous mudstone paleosols in the Yellow Cat Member 
of the Cedar Mountain Formation in Utah yielded an MDA of 136.5 \pm 1.4 Ma (Joeckel et al., 2019). The overlying Plainview Formation is interpreted to be late Aptian to mid-Albian in age, spans about 4-9 Myrs (Dolson and Muller, 1994; Willis, 1997), and displays significant variability in depositional environments and thickness from north to south along the Colorado Front Range:

- To the north near Fort Collins at Horsetooth Reservoir, the Plainview is interpreted to be a coastal plain/shoreface deposit (Holbrook and Ethridge, 1996) and a subtidal, mixed sand and mud flat deposit (Wescott, 1979).

- In the Denver area, the Plainview is interpreted to consist of estuarine, tidal channel, and near shore marine deposits (Weimer, 1970; Weimer et al., 1990).

- To the south and west of Colorado Springs near Cañon City, the Plainview is interpreted to have been deposited on a delta plain or low-gradient alluvial plain adjacent to estuarine or tidal environments (Gustason and Kauffman, 1985).

The Kiowa-Skull Creek Shale overlies the Plainview and is interpreted to consist of shallow-marine mudstones deposited during the Albian-age, Kiowa-Skull Creek transgression of the Western Interior Seaway (Weimer, 1970; Gustason and Kauffman, 1985; Holbrook and Ethridge, 1996). The Dakota Formation is the uppermost unit examined in this study and has been interpreted to be late Albian to Cenomanian in age, with the top of the unit dated at ca. 95 Ma (Weimer, 1984) based on faunal assemblages. The stratigraphically equivalent Muddy Formation from the Bighorn Basin in Wyoming yielded DZ U-Pb age peaks of ca. 100-101 Ma, with youngest grains of ca. $92.8 \pm 1.8 \mathrm{Ma}$ and ca. $91.3 \pm 3.0 \mathrm{Ma}$ (May et al., 2013). The only geochronology available for the equivalent Dakota Group in the US midcontinent is a U-Pb Concordia age of $95.5 \pm 0.4 \mathrm{Ma}$ of a bentonite from the Rose Creek Escarpment along the 
Nebraska-Kansas border (Ludvigson et al., 2017) and a single young grain from a sandstone in Nebraska with a U-Pb age of $95.4 \pm 2.3 \mathrm{Ma}$ (Finzel, 2014).

Generally, the Dakota consists of mixed fluvial, deltaic, and shallow-marine strata deposited on the western margins of the Western Interior Seaway during the Kiowa-Skull Creek transgression, but varies regionally:

- At Horsetooth Reservoir near Fort Collins, the Dakota is referred to as the Muddy Sandstone, and has been split into two members: the lower Fort Collins Member is interpreted to be a late highstand delta-front deposit, whereas the upper Horsetooth Member is interpreted to be fluvial and estuarine deposits (Dolson and Weimer, 1992; Holbrook and Ethridge, 1996).

- In the Denver area, the Dakota is interpreted to represent progradational deltaic strata overlain by fluvial deposits (Weimer, 1970).

- The Dakota near Cañon City is referred to as the Muddy Sandstone and has been subject to alternative interpretations. Gustason and Kauffman (1985) interpreted the Dakota to represent meandering stream deposits aggrading a previously scoured paleovalley, with marine influence increasing upward resulting in estuarine and tidal deposits. Other authors have interpreted the Dakota in this region to represent delta plain deposition (Waagé, 1953; 1955; Long, 1966; Altschuld, 1980).

Aptian to Cenomanian strata were deposited elsewhere in the midcontinent and are called by different names (Table 1). As noted above, the Lytle-equivalent basal Cretaceous unit in SW Kansas is named the Cheyenne Sandstone, which has been interpreted as a fining-upward unit deposited in meandering fluvial and estuarine environments prior to the incursion of the KiowaSkull Creek seaway (Franks, 1975; Hamilton, 1994; Brenner et al., 2000; Ludvigson et al., 
2010). In the Black Hills of South Dakota, and in the Powder River Basin of Wyoming and Montana, and in the Bighorn Basin of Wyoming, the basal Cretaceous Lakota and Cloverly Formations are also interpreted as fluvial sandstones (Waagé, 1958; 1959; Moberly, 1960; Gries, 1962; Ostrom, 1970; Kvale, 1986; Dahlstrom and Fox, 1995; Way et al., 1998). Plainview equivalent strata have been called the Fall River Formation (Bolyard and McGregor, 1966) in the Powder River Basin of Wyoming and the Black Hills of South Dakota, and the Sykes Mountain Formation in the Bighorn Basin in Wyoming (Moberly, 1960). Similar to the Plainview in Colorado, these units are interpreted to consist of a variety of fluvial, deltaic, and estuarine depositional environments (Miller, 1962; Berg, 1968; Campbell and Oaks, 1973; Rasmussen et al., 1985; Haerter, 1990; Kvale and Vondra, 1993; Willis, 1997).

Finally, Albian to Cenomanian strata in Kansas and Nebraska are called the Dakota Formation, with the original type area located in NE Nebraska and NW Iowa (Witzke and Ludvigson, 1994). In spite of nomenclatural differences, these units are generally interpreted to consist of shallow-marine, deltaic, and fluvial to estuarine strata that are linked to the eastern margins of the Western Interior Seaway following the Kiowa-Skull Creek transgression (Moore et al., 1951; Brenner et al., 2000; Ludvigson et al., 2010).

\subsection{Broader Context}

Multiple models have been proposed for Aptian to Cenomanian paleodrainage and sediment routing in North America and for how sediment dispersal patterns changed during this time period. Early research on these Front Range deposits of interest proposed paleodrainage models using various paleoflow indicators and different stratigraphic models. In the Denver area, the Lytle through Dakota succession has been interpreted to represent a N-NE-E flowing 
stream system (Weimer, 1970), consistent with paleoflow data from the Lower Cretaceous Lytle equivalent (Cloverly Formation) in Wyoming, which also shows a N-NE-E trend (MacKenzie and Ryan, 1962; Zaleha, 2013). However, other studies interpret SE-flowing valley networks in the Dakota "Muddy Sandstone" from the Denver basin area (Weimer and Sonnenberg, 1982; Dolson et al., 1991) and a N-S trend near Denver and in northwestern Colorado (Kirkwood, 1977; Dolson et al., 1991). In the midcontinent, paleoflow data from the Dakota Formation in Kansas and southeastern Nebraska shows a W-NW trend (MacKenzie and Poole, 1962; Karl, 1976; Phillips Jr. et al., 2007), as does the Plainview equivalent Fall River Formation in the Black Hills (MacKenzie and Ryan, 1962; MacKenzie and Poole, 1962).

Blum and Pecha (2014) used DZ U-Pb data from the Aptian-Albian Mannville Group of the Western Canada Sedimentary Basin (WCSB) to interpret an Early Cretaceous continentalscale drainage basin with distal headwaters that stretched from the Appalachian and Ouachita Mountains in the southeast US to the SFTB in the southwest US; in this model, river systems from the west and southwest converged with river systems from the Appalachian-Ouachita Cordillera, and then flowed north to the Boreal Sea. This interpreted Mannville paleodrainage system is inferred to have produced reservoir sandstones that house the Alberta Oil Sands (Hein et al., 2013). By the Paleocene, however, fluvial systems of the western US were rerouted to the Gulf of Mexico and only the most northern areas of the US drained to the north and/or east (Figure 1) (Blum and Pecha, 2014; Blum et al., 2017; Sharman et al., 2017). A contemporaneous DZ U-Pb study of the Lower Mannville McMurray Formation in Alberta by Benyon et al., $(2014 ; 2016)$ proposes three different scenarios for Early Cretaceous sediment routing to the WCSB: (a) sediments were derived directly from the Appalachians, (b) sediments were derived from recycling of Mesozoic eolianites in the southwestern US; or (c) sediments were derived 
from recycling of older Mesozoic strata of the US midcontinent and the Canadian Shield, but with no confluence of primary Appalachian- or western-sourced river systems like Blum and Pecha (2014) interpreted (Figure 2) (Benyon et al., 2014; 2016). 


\section{Methods}

\subsection{Field Methodology and Measured Sections}

$\mathrm{DZ} \mathrm{U-Pb}$ age populations have become increasingly used to reconstruct paleodrainage and sediment routing in North America since a pioneering paper by Riggs et al. (1996). DZ U$\mathrm{Pb}$ geochronology has since become a well-established method in provenance analyses with notable studies by DeCelles et al. (2000), Rainbird et al. (2001), Dickinson and Gehrels (2008), Gehrels et al. (2011), Licht et al. (2016), and many others. Samples for DZ U-Pb provenance and geochronology from sites in the Colorado Front Range, the Black Hills of South Dakota, and the Great Plains of Nebraska and Kansas were initially collected to test the Blum and Pecha (2014) model for sediment routing to the Alberta foreland. Beginning in 2014, additional samples were collected in the Front Range to provide a broader regional perspective.

Locations for DZ U-Pb samples include sites along the Colorado Front Range from Fort Collins to Cañon City, and farther southeast in Purgatoire Canyon, within the Comanche National Grassland. These sample sites were chosen based on previous studies, accessibility, and spacing so as to provide representative geographic coverage in a N-S transect in order to sample potential west-derived fluvial systems. DZ U-Pb samples from sites in South Dakota, Nebraska, and Kansas are used to define potential age-equivalent east-derived fluvial systems. A map of site locations used in this study is shown in Figure 3.

Stratigraphic sections were measured at six different sites along the Colorado Front Range using a $1.5 \mathrm{~m}$ Jacob staff. Lithology, sedimentary structures, grain size, and trace fossils are reported for each unit. Sample locations were recorded using GPS (Table 3) and measured sections are available in Appendix A. No further work was conducted on sample locations in South Dakota, Nebraska, and Kansas but DZ U-Pb data from these locations are used herein. 


\subsection{Detrital Zircon U-Pb Dating and Statistical Analysis}

Zircons are produced in igneous and metamorphic rocks (the protolith sources) and acquire their $\mathrm{U}-\mathrm{Pb}$ age as they cool below $800^{\circ} \mathrm{C}$. After cooling and crystallization, they are exhumed, eroded, transported, and eventually deposited in sedimentary rocks as detrital grains. Detrital zircon protolith sources in North America are well known and primary age populations correspond to major Laurentian orogenic cycles. Moreover, analyses of DZ U-Pb age populations in numerous stratigraphic successions have provided insight into the recycling of age populations over geologic time (Figure 4, Table 2) (Dickinson and Gehrels, 2009; Laskowski et al., 2013; Gehrels and Pecha, 2014; Blum et al., 2017).

As described by Gehrels (2012), the youngest DZ U-Pb age population provides the maximum depositional age (MDA) of a stratigraphic unit. MDAs can approximate the true depositional age (TDA) of a stratigraphic unit if contemporaneous volcanism expels zirconbearing ash that falls out within the drainage basin and is incorporated into the sediment load (Blum et al., 2017). If zircon protoliths are intrusive, MDAs will be older than the TDA due to the time required for exhumation, erosion, and incorporation into the fluvial system. Other factors to consider when determining MDAs include Pb-loss and discontinuous magmatic activity in the drainage area during the time period being studied (Pullen et al., 2014). The latter is an important problem for this study because there were high-flux events in the Western Cordilleran magmatic arc during the Late Jurassic and Late Cretaceous, contemporaneous with deposition of Morrison and Dakota strata. However, Lytle and Plainview deposition is thought to have occurred during a well-documented Early Cretaceous magmatic lull, such that there are a relatively small number of volcanogenic zircons of this age in Sevier foreland basin strata 
(Figure 5) (Armstrong and Ward, 1993; Ducea, 2001; DeCelles, 2004; DeCelles et al., 2009;

May et al., 2013).

\subsection{Detrital Zircon U-Pb Analytical Methods}

A total of 22 DZ samples were collected from the Late Jurassic Morrison Formation, the Aptian-Albian Lytle and Plainview formations (and age-equivalents), and the Albian to Cenomanian Dakota Formation. Heavy mineral separation for all samples was completed at the Arizona Laserchron Center (ALC) of the University of Arizona and all $\mathrm{U}-\mathrm{Pb}$ analyses were done at the ALC using Laser Ablation Multicollector Inductively Coupled Plasma Mass Spectrometry (LA-MC-ICPMS), following the methodology in Appendix B (see also Gehrels, 2012; 2014).

After mineral separation and mounting, spots with a diameter of $20 \mu \mathrm{m}$ within a $40 \mu \mathrm{m}$ diameter cleaning pit were identified in the interior of each zircon, avoiding parts of the grain with obvious zonation and inclusions. First-generation EMURC samples were initially analyzed in 2013 for $n=100$ grains per sample. Samples collected after that time were analyzed for target populations of $n=300$, which results in a more statistically robust analysis (Dodson et al., 1988; Fedo et al., 2003; Andersen, 2005; Pullen et al., 2014; Saylor and Sundell, 2016). Moreover, seven of the original EMURC samples from the Colorado Front Range, the Lytle/Lakota sample from the South Dakota Black Hills, and the Lytle/Cheyenne sample from southwestern Kansas were upgraded to a target population of $n=300$ at this time as well: Dakota samples from South Dakota, Nebraska, and Kansas were not upgraded due to their simple U-Pb populations. All sample results are included in Appendix C. For each grain, the "best age" reported here consists of the ${ }_{207} \mathrm{~Pb} / 206 \mathrm{~Pb}$ age for grains older than $0.8-1.0 \mathrm{Ga}$, and the $206 \mathrm{~Pb} / 238 \mathrm{U}$ age for grains younger than 0.8-1.0 Ga, due to inherent uncertainties with $\mathrm{Pb}$ loss associated with $\mathrm{U}-\mathrm{Pb}$ decay systems 
(Gehrels, 2000; Gehrels et al., 2008). Ages that are $>20 \%$ discordant or $>5 \%$ reverse discordant were excluded from further analyses.

$\mathrm{DZ} \mathrm{U}-\mathrm{Pb}$ age distributions were analyzed and samples were compared to each other to identify similarities and differences using statistical techniques based on scripts developed and published by Vermeesch et al. (2016) (http://www.ucl.ac.uk/ ucfbpve/provenance/). Statistical techniques used for DZ visualization and analysis of $\mathrm{DZ} \mathrm{U}-\mathrm{Pb}$ age populations include:

a. Kernel Density Estimates (KDEs), which illustrate the contributions of different age populations within each sample and facilitate comparisons between samples. KDE plots for each sample are normalized to each other, so that the area under the curve is the same: normalized KDE plots then provide a visual representation of the true $\mathrm{DZ} \mathrm{U}-\mathrm{Pb}$ age distribution for each sample, which can be compared to other samples.

b. Pie charts, which illustrate DZ U-Pb age distributions for each sample, were generated by dividing the number of grains found within each specific age population by the total number of grains in the sample. Analyses where the uncertainty fell within the specified age range were also included. Analyses that fell within two populations based on uncertainty were included in the population with which the age was closest.

c. Multidimensional scaling (MDS), which allows for objective comparison and visualization of the statistical similarity and dissimilarity between samples (Borg and Groenen, 2005; Vermeesch, 2013; 2016). 2-dimensional MDS analyses result in a maplike plot where the distance between samples is a function of their Kolmogorov-Smirnov (KS) dissimilarities. Samples that are statistically similar plot closest to each other and statistically dissimilar samples plot farther apart. This method therefore identifies 
clusters of samples with similar age distributions, which are then assumed to represent the same or similar source area.

d. Maximum depositional ages (MDAs) were calculated using the mean age of the youngest grains with overlapping $1 \sigma$ error terms for each sample (Dickinson and Gehrels, 2009). MDAs reported herein have MSWD (mean square weighted deviation) values $\leq 1$, which indicate the ages used for the calculations are likely from zircons of the same population with the same TDA. It is assumed that the zircons are the same "true" age and that the scatter is attributable to the uncertainties. MDAs in this study were calculated using an excel macro developed by the ALC (https://drive.google.com/file/d/0B9ezu34P5h8eT196SzRtXzB5YXM/view).

\subsection{Paleodrainage Reconstruction}

Paleodrainage organization represented by the samples examined herein is interpreted using composite age distributions, the presence or absence of age peaks in KDE plots, and clusters apparent in MDS plots. Age distributions were compared to maps of North American source terrains (Laskowski et al., 2013), paleodrainage interpretations from past studies (Benyon et al., 2014, 2016; Blum and Pecha, 2014), age distributions of DZ U-Pb samples from the Alberta Oil Sands, and paleoflow indicators, so as to provide new insight into paleodrainage and sediment routing. 


\section{Results}

\subsection{Alluvial Architecture and Sedimentological Observations}

Basic sedimentological characteristics of each study location in the Colorado Front Range were recorded within the context of measured sections. Rather than describe each section in detail, all sections are included in Appendix A and a type section is included in Figure 6. Key sedimentological and stratigraphic observations and key differences between sections are as follows:

- There is a consistent general stacking pattern observed at all study locations. The Morrison Formation deposits consist interbedded purplish and greyish mudstone and very fine- to fine-grained, discontinuous sandstone beds. Sandstones are generally either structureless or trough cross bedded. The Lytle Formation scours and truncates the Morrison and its deposits generally consist of thick, amalgamated, trough cross bedded, medium- to coarse-grained sandstone containing granules and pebbles in an overall succession that fines upward into fine-grained sandstone with minor mudstone beds. The overlying Plainview consists of fine- to medium-grained sandstone that thins and fines upward from trough cross bedded into ripple laminated structures that are interbedded with mudstone and include trace fossil assemblages that typically indicate brackish or marine influence. The Kiowa Skull Creek Shale (KSCS) then consists of interbedded mudstone, siltstone, and very fine-grained, thin ripple-laminated and bioturbated sandstone, with mudstone making up the majority of the formation. The overlying Dakota Formation can be split into two parts. The lower Dakota consists of a coarseningupwards succession of thin bedded, very fine- to fine-grained, ripple-laminated, and bioturbated sandstone with occasional mudstone or siltstone, whereas the upper Dakota 
consists of thick, amalgamated, trough cross bedded, fine- to medium-grained sandstone that lacks significant bioturbation.

- The thickness of the KSCS succession and the lower coarsening-upwards succession of the Dakota Formation varies considerably between locations observed in this study. The KSCS is thinnest at Dinosaur Ridge (Appendix A5) at only $\sim 1.5 \mathrm{~m}$, a sharp contrast to Horsetooth Reservoir (Appendix A2), where it is at its thickest at $\sim 44 \mathrm{~m}$.

- The thickness of the Lytle Formation also varies between sites. Among study locations used in this report where it could be measured, the Lytle varies from $\sim 8-32 \mathrm{~m}$. It is thinnest at Skyline Drive (Appendix A3, A4) and thickest at I-70 Morrison (Appendix A7).

Basic measurements were also taken at study locations. Channel-belt thicknesses of sand bodies were measured from the thickness of large-scale, inclined-strata sets, which are known to scale to bankfull depth. Thicknesses of the sets measured in this study varied by formation as well as location and range from 5.1-20.1 m, with a mean value of $12.0 \mathrm{~m}(\mathrm{n}=11)$ and a standard deviation $(2 \sigma)$ of $=8.0 \mathrm{~m}$ (Table 6). Inclined strata sets from the Lytle Formation ranged from 10.4-20.1 m, with a mean value of $14.8 \mathrm{~m}(\mathrm{n}=5)$ and a standard deviation $(2 \sigma)$ of $=8.2 \mathrm{~m}$, whereas sets from the Plainview Formation ranged from 5.1-12.7 m, with a mean value of $9.9 \mathrm{~m}$ $(\mathrm{n}=4)$ and a standard deviation $(2 \sigma)$ of $=6.6 \mathrm{~m}$. Sets from the Dakota Formation ranged from 8.7-9.2 m, with a mean value of $9.0 \mathrm{~m}(\mathrm{n}=2)$ and a standard deviation $(2 \sigma)$ of $=0.7 \mathrm{~m}$.

Paleoflow depths were calculated using the methods proposed by Leclair and Bridge (2001). Cross bed set thicknesses were measured and mean bedform height $\left(\mathrm{h}_{\mathrm{m}}\right)$ was calculated using the mean cross bed thickness $(\mathrm{sm})$ for each field location using $\mathrm{hm}=2.9( \pm 0.7) * \mathrm{sm}$. Flow depth (d) was then calculated using the empirical relationship provided by Allen (1970): $d=11.6$ 
* $(\mathrm{hm}) 0.84$. Cross bed set thicknesses ranged from $35-150 \mathrm{~cm}$, mean bedform height ranged from 1-4.4 m, and calculated flow depth ranged from 5.6-19.1 m (Table 7). Calculated flow depths from the Morrison Formation ranged from 5.6-6.3 m, with a mean depth of $6.0 \mathrm{~m}(\mathrm{n}=4)$ and a standard deviation $(2 \sigma)$ of $=0.8$. Calculated flow depths from the Lytle Formation ranged from 6.3-19.1m, with a mean depth of $10.7 \mathrm{~m}(\mathrm{n}=8)$ and a standard deviation $(2 \sigma)$ of $=10.3$. Calculated flow depths from the Plainview Formation ranged from 6.3-13.0 m, with a mean depth of $9.9 \mathrm{~m}(\mathrm{n}=4)$ and a standard deviation $(2 \sigma)$ of $=5.6$. Calculated flow depths from the Dakota Formation ranged from 7.6-10.7 m, with a mean depth of $8.7 \mathrm{~m}(\mathrm{n}=6)$ and a standard deviation $(2 \sigma)$ of $=2.1$. In each case, flow depths estimated from cross-bed set thicknesses are consistent with flow depths indicated by thicknesses of large-scale inclined strata.

\subsection{Detrital Zircon U-Pb Age Populations}

$\mathrm{DZ} \mathrm{U}-\mathrm{Pb}$ age populations from Late Jurassic Morrison through Albian to Cenomanian Dakota strata of the Colorado Front Range and US midcontinent record fluvial sediment transport from specific source terrains. The $22 \mathrm{DZ}$ samples used in this study include a total of 5756 U-Pb ages: 94\% of this total represent Western Cordilleran magmatic arc (ca. <275 Ma; 10\% of total), Appalachian (ca. 300-500 Ma; 13\%), Peri-Gondwanan (ca. 500-750 Ma; 8\%), Grenville (ca. 950-1250 Ma; 36\%), Mid-Continent (ca. 1300-1550 Ma; 10\%), and YavapaiMazatzal (ca. 1600-1800 Ma; 9\%), Penokean and Trans-Hudson (ca. 1800-2000 Ma; 4\%) and Wyoming or Superior (ca. >2500 Ma; 4\%) protolith sources (Figure 7), although many of these populations are recycled from older sedimentary rocks. U-Pb ages that do not fall within the well-defined populations are labeled as "Other" $(6 \%)$. The interpreted ultimate protolith and potential recycled sources for each DZ U-Pb age populations can be found in Table 2. 
$\mathrm{U}-\mathrm{Pb}$ age distributions for samples from the Morrison, Lytle, and Dakota formations (and their equivalents) are shown as normalized KDEs in Figures 8, 9, and 10, whereas the geographic locations and average percent contribution of different age populations for each sample are shown as pie charts in Figures 11, 12, and 13. The following summarizes general trends in age populations that can be observed from each formation, differentiating between first-cycle Mesozoic Western Cordilleran magmatic arc populations, which are interpreted to fingerprint a western source, versus potential recycled Paleozoic and older populations with ultimate protolith sources from the east. Among the potential recycled sources, 57\% of all U-Pb ages fall within the Appalachian, Peri-Gondwanan, and Grenville populations that represent the primary signature of the Appalachian-Ouachita Cordillera (e.g. Thomas et al., 2017), but were also present in western Laurentian margin strata, having been transported to the west during the late Paleozoic and early Mesozoic and then entrained in the Sevier fold and thrust belt (SFTB) (Gehrels and Pecha, 2014). When this set of populations co-occurs with arc-derived grains, it is interpreted to represent, and referred to herein, as the recycled Appalachian-Ouachita age population, which distinguishes it from a primary Appalachian-Ouachita age population that is not associated with arc-derived grains. The interpreted recycled Appalachian-Grenville populations are also commonly associated with significant Mid-Continent and Yavapai-Mazatzal populations, whereas primary Appalachian-Grenville populations are not.

A total of $1187 \mathrm{U}-\mathrm{Pb}$ ages were obtained from four Morrison Formation samples collected along the Colorado Front Range, with KDE plots and pie charts shown in Figures 8 and 11. Key characteristics are summarized as follows: 
- The contribution of Western Cordilleran magmatic arc grains generally increases from north to south, from 5\% in DBK-21 from Horsetooth Reservoir to 20\% in DBK25 from Purgatoire.

- Apart from the arc signature, all four Morrison samples are dominated by the recycled Appalachian-Ouachita age population but include a broad range of older Proterozoic and Archean populations as well and are generally similar with respect to one another. Moreover, the range in percent contribution from individual age populations between samples is low.

A total of $1756 \mathrm{U}-\mathrm{Pb}$ ages were obtained from six Lytle Formation (and equivalent) samples and one Plainview Formation sample, with KDE plots and pie charts shown in Figures 9 and 12. Key characteristics are summarized as follows:

- All samples from Lytle and age-equivalent strata in Colorado, South Dakota, and Kansas have zircons derived from the Western Cordilleran magmatic arc. The relative contribution of arc-related grains generally increases from north to south, from 5\% in DBK-11 from the Black Hills in South Dakota, to 13\% in DBK-23 from Purgatoire in Colorado. For DBK-16, the Cheyenne Sandstone in southcentral Kansas, the arc-related population comprises $9 \%$ of the total.

- All samples from Lytle and age-equivalent strata in Colorado, South Dakota, and Kansas are dominated by recycled Appalachian-Ouachita populations, but include a broad range of older Proterozoic and Archean populations as well: they are generally similar with respect to each other, and there is a low range in variability in contributions from individual age populations. 
A total of $2438 \mathrm{U}-\mathrm{Pb}$ ages were obtained from 11 samples from the Dakota Formation and equivalents, with KDE plots and pie charts shown in Figures 10 and 13. Key characteristics are summarized as follows:

- All Dakota samples collected within and just to the east of the Colorado Front Range contain first-cycle zircons derived from the Western Cordilleran magmatic arc. The relative contribution of arc grains generally decreases from north to south, with $23 \%$ in DBK-22 from Horsetooth Reservoir, 10\% in DBK-24 from Purgatoire, and 8\% in DBK-01 from John Martin Reservoir. Dakota samples in Kansas, Nebraska, and South Dakota (DBK-09, DBK-12, DBK-13, DBK-14, DBK-15, DBK-17) lack the Western Cordilleran magmatic arc population.

- All Dakota samples are dominated by the Appalachian-Ouachita age populations: this population is interpreted to be recycled in samples from Colorado because of its association with arc-derived grains, whereas it is likely a primary signature in samples from South Dakota, Nebraska, and Kansas. The recycled AppalachianOuachita age population from samples in Colorado include contributions from the Peri-Gondwanan (ca. 500-750 Ma) and Yavapai-Mazatzal (ca. 1600-1800 Ma) age populations, whereas samples from Kansas, Nebraska, and South Dakota generally lack significant contributions from these populations. Primary Appalachian-Grenville populations in samples from South Dakota, Nebraska, and Kansas (DBK-09, DBK12, DBK-13, DBK-14, DBK-15, DBK-17) also include a Grenville contribution that is $\sim$ twice that found in samples from Colorado.

- DBK-01 (John Martin Reservoir) has percent contributions of different age populations that are transitional between the western and eastern Dakota sample 
groups defined above, with percentages of different age populations that generally fall between the averages for the two groups.

DZ U-Pb populations that represent the Western Cordillera magmatic arc and the Appalachian-Ouachita Cordillera are therefore fundamental to any discussion of Late Jurassic-Cenomanian paleodrainage and sediment routing. All samples include significant populations that were ultimately derived from the Appalachian-Ouachita Cordillera, whereas U$\mathrm{Pb}$ ages $<275 \mathrm{Ma}$ from the magmatic arc are present only in samples from Colorado, the Cheyenne Sandstone in Kansas (DBK-16) and the Lakota Formation from South Dakota (DBK11). The presence of arc grains fingerprints a Sierra Nevada source, and generally west-derived fluvial systems, such that Appalachia-Ouachita Cordillera populations in these samples must be recycled from the western Laurentian margin and SFTB (e.g. Laskowski et al., 2013, Gehrels and Pecha, 2014). By contrast, the absence of this arc population in Dakota Formation samples from South Dakota, Nebraska, and Kansas is consistent with east-derived fluvial systems with a primary Appalachian-Ouachita Cordillera source.

Additional details within the $\mathrm{U}-\mathrm{Pb}$ age populations are worthy of mention:

- From the published literature, the Western Cordillera magmatic arc population is known to display prominent peaks at ca. $160 \mathrm{Ma}$ and ca. $100 \mathrm{Ma}$, which correspond to high magmatic flux events (Figure 5) (Barton, 1990; Armstrong and Ward, 1993; Ducea, 2001; DeCelles et al., 2009; Laskowski et al., 2013). Morrison and Lytle samples have the Jurassic-age ca. 160 Ma peak, which is consistent with their presumed depositional ages, whereas Dakota samples have both peaks (Figure 14).

- Grains that were ultimately derived from the Appalachian-Ouachita Cordillera comprise 57\% of all samples, and all samples include well-defined Appalachian and Grenville age 
populations. However, Peri-Gondwanan grains are more abundant in the west-derived Morrison, Lytle, and Dakota samples from Colorado, and completely lacking in some of the east-derived Dakota samples from Kansas and Nebraska. This population is ultimately derived from the Appalachian-Ouachita Cordillera (Link et al., 1993; Laskowski et al., 2013; Thomas et al., 2017) and represents a significant component of the large-scale east-to-west sediment routing that took place in the late Paleozoic and early Mesozoic (Dickinson and Gehrels, 2010; Gehrels and Pecha, 2014). However, by the Cretaceous, this population was available to west-derived systems as a recycled component, but no longer significant for river systems that directly drained the Appalachians.

- The Grenville population in all samples displays two prominent peaks at ca. $1050 \mathrm{Ma}$ and ca. 1160 Ma (Figure 15), which correspond to the well-documented Ottawan and Shawinigan orogenies, respectively (Heumann et al., 2006).

\subsection{Multidimensional Scaling (MDS)}

Samples from the Morrison, Lytle, and Dakota formations were compared using multidimensional scaling (MDS), where the Euclidian distance between samples represents their statistical dissimilarity (Figure 16). Although MDS algorithms calculate differences in $\leq \mathrm{n}$ dimensions where $\mathrm{n}$ is the number of samples, the explanatory power of each successive dimension decreases exponentially, hence the first 2-3 dimensions are most useful (Vermeesch, 2013). The apparent differences in age populations from KDE plots and pie charts illustrated in Figures 8-13 provide a basis for explanation of MDS clusters that define samples that are statistically similar and dissimilar. 
As shown in Figure 16A, Morrison Formation samples split into two clusters, with DBK20 and DBK-25 from Penrose and Purgatoire to the south comprising one, and DBK-05 and DBK-21 from I-70 Morrison and Horsetooth Reservoir farther north comprising the other. The most importance difference between these two clusters is the percent contribution of the Western Cordilleran magmatic arc population, as discussed above (see Figures 8 and 11).

Samples from the Lytle Formation in Colorado and age-equivalent strata from the US midcontinent plot in two clusters as well (Figure 16B), where DBK-11 (Lakota at Rapid City,SD), DBK-06 (Lytle at Horsetooth Reservoir), and DBK-16 (Cheyenne at Belvidere) comprise one, and DBK-04 (Lytle at I-70 Morrison), DBK-18 (Lytle at Penrose), and DBK-23 (Lytle at Purgatoire) comprise the other. Interestingly, DBK-06 from the Lytle Formation at Horsetooth Reservoir and DBK-11 from the Lakota Formation at Rapid City are closely related, have the same percent contribution of Western Cordilleran magmatic arc grains, plot in similar positions relative to the $\mathrm{X}$-dimension, and have similar age peaks in their KDE plots (see Figure 9). More generally, the relative contribution of the magmatic arc population increases in samples from the Lytle and age-equivalent strata from left to right in the X-dimension in Figure 16B, with DBK-06 and DBK-11 at 5\% and DBK-23 (Purgatoire) at 13\%. Also notable, DBK-03 is from the Plainview Formation, and overlies the Lytle at the I-70 Morrison location, but has DBK-16 (Cheyenne at Belvidere) as its closest neighbor and DBK-23 (Lytle at Purgatoire) as its second closest.

Dakota samples form two distinct clusters in Figure 16C, which generally correspond to the west- vs. east-derived samples collected from the Colorado Front Range and the US midcontinent, respectively, which are themselves distinguished by the presence or absence of the magmatic arc population: the west-derived cluster on the right includes DBK-24 (Dakota at 
Purgatoire), DBK-19 (Dakota at Penrose), DBK-26 (Dakota at I-70 Morrison), and DBK-22

(Dakota at Horsetooth Reservoir), whereas the cluster on the left includes DBK-12 (Dakota at Red Canyon, SD), DBK-09 (Dakota at Rapid City, SD), DBK-12 (Dakota at Dakota City, NE), DBK-14 (Dakota at Ashland, NE), DBK-15 (Dakota at Washington, KS), DBK-17 (Dakota at Salina, KS). As noted above, samples in the east-derived cluster in Figure 16C have no Western Cordilleran magmatic arc contribution (except see below) and significantly higher Grenville contributions than those in the west-derived cluster on the right, with mean values of $64 \%$ and $26 \%$, respectively.

DBK-01 (Dakota at John Martin Reservoir) is geographically closer to DBK-24 (Dakota at Purgatoire) and DBK-19 (Dakota at Penrose) in the west-derived cluster, but is statistically most similar to DBK-12 and DBK-15 from Kansas in the east-derived cluster. DBK-01 has a Western Cordilleran magmatic arc contribution of $8 \%$, which is lower than that of the other westderived Dakota samples, where samples have an average arc contribution of $17 \%$. Moreover, DBK-01 also has intermediate values for percent contributions for the Peri-Gondwanan, Grenville, and Yavapai-Mazatzal age populations. DBK-01 is therefore enigmatic and dissimilar from other Dakota samples.

Uncertainty in MDS plots is estimated by the "stress parameter", which evaluates the quality of the MDS fit. The fit is considered "perfect" for stress values of $0 \%$, excellent for values of $2.5 \%$, good for values of $5 \%$, fair for values of $10 \%$, and poor for values of $20 \%$ (Kruskal, 1964; Vermeesch, 2013). The stress values for the MDS plots in Figures 14A-C are $1.77-10 \%, 6.91 \%$, and 5.41\%, respectively. These values indicate "perfect" to fair fits, but additional dimensions beyond the two used in this study may yield better results. 


\subsection{Maximum Depositional Ages (MDAs)}

MDAs were calculated for samples with 2 or more young volcanogenic zircons, which is the case for 3 of 4 Morrison samples (Figure 17; Table 4) and 4 of 5 Dakota samples from Colorado (Figure 18; Table 4). All MDA ages have MSWD values $\leq 1$, which indicates the ages used in the calculation are consistent with sampling grains of the same true age, and are reported with $2 \sigma$ uncertainty. Morrison samples DBK-20 (Penrose), DBK-05 (I-70 Morrison), and DBK25 (Purgatoire) produced MDAs of $147.6 \pm 3.1 \mathrm{Ma}(\mathrm{n}=7, \mathrm{MSWD}=0.2), 148.7 \pm 2.3 \mathrm{Ma}(\mathrm{n}=8$, MSWD=0.1), and $149.6 \pm 2.5 \mathrm{Ma}(\mathrm{n}=7, \mathrm{MSWD}=0.1)$, respectively, which are slightly younger than those previously published $40 \mathrm{Ar} / 39 \mathrm{Ar}$ ages from sanidine grains in bentonites (Kowallis et al., 1998; Trujillo and Kowallis, 2015). However, the majority of the $40 \mathrm{Ar} / 39 \mathrm{Ar}$ ages are not from the uppermost Morrison Formation, like the new MDAs presented here, and are from Utah, not Colorado.

Dakota samples DBK-01 (John Martin Reservoir), DBK-19 (Penrose), DBK-26 (I-70 Morrison), and DBK-22 (Horsetooth Reservoir) produce MDAs of 96.2 $\pm 4.3 \mathrm{Ma}(\mathrm{n}=2$, MSWD=0.01), $98.1 \pm 1.9 \mathrm{Ma}(\mathrm{n}=7, \mathrm{MSWD}=0.04), 99.2 \pm 1.7 \mathrm{Ma}(\mathrm{n}=12, \mathrm{MSWD}=0.3)$, and 99.6 $\pm 1.6 \mathrm{Ma}(\mathrm{n}=5, \mathrm{MSWD}=0.1)$, respectively. These ages are slightly older than previous age estimates based on faunal assemblages (Weimer, 1984).

Lytle (and age-equivalent) samples and the Plainview sample from I-70 Morrison (DBK03) did not produce young syndepositional zircons, which is consistent with an Aptian to early Albian age that corresponds to the well-documented Early Cretaceous lull in the Western Cordilleran magmatic arc (Figure 5) (Armstrong and Ward, 1993; Ducea, 2001; DeCelles, 2004;

DeCelles et al., 2009; May et al., 2013). East-derived Dakota samples from South Dakota, Nebraska, and Kansas did not produce any zircons of Mesozoic age, which is consistent with 
their east-derived provenance, and the general lack of volcanism in the eastern US during this time period. The youngest $\mathrm{U}-\mathrm{Pb}$ ages for the Lytle (and age-equivalent) and east-derived Dakota samples are included in Table 4. The youngest grains within Lytle samples are similar to, or older than, MDAs calculated for the underlying Morrison Formation, whereas the youngest grains within the east-derived Dakota samples are Devonian to Carboniferous in age. 


\section{Discussion}

Results presented above are discussed with reference to three specific topics: a) field observations and measurements that provide for interpretation of depositional environments and scales of the Early Cretaceous fluvial systems represented by the Late Jurassic through Cenomanian strata; b) the significance of $\mathrm{DZ} \mathrm{U}-\mathrm{Pb}$ age populations for reconstruction of Morrison, Lytle, and Dakota paleodrainage and sediment routing; and c) MDAs that resulted from $\mathrm{DZ} \mathrm{U}-\mathrm{Pb}$ analyses, which improve the geochronological framework for Late Jurassic to Late Cretaceous deposition in the Colorado Front Range.

\subsection{Sedimentology}

Interpretations of the environment of deposition and depositional characteristics can be made for the stratigraphic units studied along the Colorado Front Range using previous published observations and new data presented above. Additionally, thickness measurements for large-scale, inclined-strata sets and cross bed sets can be used to provide first-order estimates of fluvial system scales.

\subsubsection{Alluvial Architecture}

Differences in the fluvial styles of the rivers that deposited the Morrison, Lytle, and Dakota formations are examined by characterizing and contrasting the alluvial architectures and broader stratigraphic patterns for each unit. The Morrison Formation is interpreted to have been deposited by a meandering fluvial system on a broad floodplain, consistent with previous interpretations (see above) (Figure 20A). The Morrison includes isolated and discontinuous channel-belt sandstones that are not laterally extensive and therefore likely have low width-to- 
thickness ratios. Channel-belt sandstones are encased in floodplain and lacustrine mudstones that include thin coarsening-up sandstones and are interpreted to represent crevasse-splay deposits. This type of architecture is interpreted to be indicative of a generally aggradational system dominated by avulsion. Overall, the Morrison has a low sandstone to mudstone ratio.

The Lytle Formation, by contrast, scours into and truncates the Morrison at nearly every study location and is interpreted to represent a mixed bedrock-alluvial valley system, where the river is confined within a broad incised valley that was cut into underlying bedrock (Figure 20B). Sandstones in the Lytle are often pebble-rich to conglomeratic at their base, with large cross bed sets (40-140 cm thick). Overall, the Lytle consists of thick, amalgamated cross bedded sandstone packages and has a high ratio of sandstone to mudstone, typical of a fluvial system that was confined within a bedrock valley (Blum et al., 2013). At the I-70 Morrison, US Highway 285, and Horsetooth Reservoir localities, the Lytle is interpreted to be $\sim 17-20 \mathrm{~m}$ thick: at US Highway 285, this thickness includes a heterolithic abandoned channel fill, whereas at the I-70 Morrison and Horsetooth Reservoir sites, the Lytle sand bodies display $\sim 17 \mathrm{~m}$ or more of pebbly coarse- to fine-grained sandstone with internal surfaces that extend from top to bottom, and occur at an angle of $7^{\circ}$ relative to structural dip.

The Plainview Formation is interpreted to consist of mixed fluvial and near shore marine facies, deposited within the same previously incised bedrock valleys of the Lytle Formation (Figure 20C). Previous studies have interpreted various environments of deposition for the Plainview, with differing interpretations within and between study locations along the Colorado Front Range (see above). The different marine environments that have been proposed are interpreted to, at least in part, represent variability in the shoreline; for example, at Skyline Drive the Plainview has been argued to represent an estuarine environment (Gustason and Kauffman, 
1985), whereas in the Denver area the Plainview is interpreted to represent a tidally influenced distributary channel (Weimer, 1970; Weimer et al., 1990). Regardless, the base of the Plainview exhibits cross bedded sandstones typical of fluvial deposits, which grade upwards into ripplelaminated fine sands with mud drapes and marine trace fossils. This upward change is interpreted to represent upstream migration of the backwater reach and corresponding marine influence, due to initial transgression of the Kiowa-Skull Creek phase of the Western Interior Seaway.

The upper Kiowa-Skull Creek Shale (KSCS) and lower Dakota Formation are interpreted here to consist of an overall coarsening-upward progradational and aggradational succession of fine-grained, structureless to laminated and bioturbated marine mudstone, siltstone, and sandstone that is interpreted to represent a distal to proximal heterolithic deltaic shoreline. The overlying sand-rich top of the Dakota consists of amalgamated fluvial sandstones, interpreted to represent a fluvial system that cuts across deltaic facies during normal regression (Figure 20D). The "fluvial units" of this study are therefore interpreted to represent different types of fluvial systems. The Morrison is interpreted to represent a net aggradational system, located far inland and with no influence of an early Western Interior Seaway (the Sundance Sea), whereas the Lytle Formation is interpreted to represent a degradational system that cut valleys progressively deeper into the underlying Morrison Formation over time. This incision created much of the accommodation for Plainview fluvial and near shore marine deposits, which are interpreted to be aggradational and confined to Lytle paleovalleys, and for the Kiowa-Skull Creek marine flooding that followed. There are distinct differences in thickness between study locations, most notably in the KSCS and the deltaic facies of the overlying Dakota Formation (Table 5). These thickness variations are interpreted to be a result of step-wise incision by the 
Lytle fluvial system and formation of fluvial terraces (Figure 21), such that accommodation would have varied laterally, and the overlying seaway succession therefore varies significantly in thickness from site to site. For example, the Lytle incised the Morrison to a significantly deeper depth at US Highway 285 as opposed to Dinosaur Ridge, just a few kilometers north, which created more accommodation to be filled by marine strata before Dakota fluvial systems arrived in the vicinity. Dakota fluvial systems are interpreted to represent a third type consisting of channel belts cutting across a broad deltaic shoreline.

\subsubsection{Fluvial System Scales}

New measurements presented herein provide insight into estimating simple first-order scales of the Morrison, Lytle, Plainview, and Dakota fluvial systems. In the earlier discussion, these different units have been interpreted to represent different fluvial styles: the use of simple scaling relationships can provide insight into the size of the systems.

Large-scale, inclined-strata sets, which are interpreted to have formed by lateral accretion of point bars, were measured in the Lytle, Plainview, and Dakota formations. These measurements represent point-bar thicknesses that scale to bankfull depth and range from 5.1-20.1 m for these units (Table 6). Average set thickness for the Lytle, Plainview, and Dakota formations were found to be $14.8 \mathrm{~m}, 9.9 \mathrm{~m}$, and $9.0 \mathrm{~m}$, respectively. The scale of these largescale inclined strata sets suggest that the basal Cretaceous fluvial sandstones were deposited by fluvial systems with an average bankfull depth of $12.0 \mathrm{~m}$, with specific outcrops of the Lytle Formation showing thicknesses and inferred paleodepths up to $20.1 \mathrm{~m}$. Additionally, cross bed set thicknesses were measured in sand bodies of each unit, which can then be used to estimate paleoflow depths using methods detailed by Leclair and Bridge (2001). Based on set thicknesses 
ranging from 35-150 cm, flow depths were calculated to range from 5.6-19.1 $\mathrm{m}$ (Table 7), and average flow depths for the Morrison, Lytle, Plainview, and Dakota formations were calculated to be $6.0 \mathrm{~m}, 10.7 \mathrm{~m}, 9.9 \mathrm{~m}$, and $8.7 \mathrm{~m}$, respectively. Calculated paleoflow depths from cross bed sets are therefore consistent with values measured from inclined-strata sets.

First-order scaling relationships between point-bar thicknesses and drainage area have been established using data from modern fluvial systems (Blum et al., 2013; Milliken et al., 2018). Lytle mixed bedrock-alluvial valley rivers represent the largest of those examined in this study, with point-bar thicknesses and corresponding bankfull depths that average $\sim 15 \mathrm{~m}$ and range upwards to $20 \mathrm{~m}$. From these scaling relationships, individual Lytle rivers are interpreted to have had a contributing drainage area of $\sim 105-106 \mathrm{~km} 2$. This places the scale of the Lytle fluvial system to be similar to the modern mixed bedrock-alluvial Colorado River in Texas, which has a drainage area of $\sim 1 * 105 \mathrm{~km} 2$, or the mixed bedrock-alluvial Missouri River in the US midcontinent, which drains 1,371,000 km2 of the northern US Rocky Mountains and Great Plains before joining the Mississippi River at St. Louis (Milliman and Syvitski, 1992). The thickest paleodepths inferred for the Lytle are similar to the mixed bedrock-allvial Mississippi River at St. Louis.

At the other end of the scale spectrum, Morrison meandering rivers were the smallest of the systems in this study with point-bar thicknesses averaging $\sim 6 \mathrm{~m}$. From these scaling relationships, Morrison rivers can be interpreted to have had small contributing drainage areas of $\sim 1 * 10_{3}-10_{4} \mathrm{~km} 2$, or a more likely interpretation might be that they represent the highly distributive part of the distal Morrison, where the flow was split, each active channel carried only part of the discharge at any one time, and the thickness is therefore not a good guide to Morrison drainage areas. The DZ U-Pb record is consistent with this view, because Morrison fluvial 
systems clearly drained the Western Cordillera fold-and-thrust belt and magmatic arc, which were likely $900-1000 \mathrm{~km}$ to the west of the outcrop locations along the Colorado Front Range.

Finally, Plainview and Dakota fluvial systems were similar in scale with point-bar thicknesses and corresponding bankfull depths of $\sim 9-10 \mathrm{~m}$. From these scaling relationships, the Plainview and Dakota rivers are interpreted to have a contributing drainage area of $\sim 1 * 10_{4}-105$ $\mathrm{km} 2$. It should be noted that these scale estimates are based on first-order relationships, which have inherent error and uncertainty. However, these estimates are valuable in providing a sense of scale to Late Jurassic and Early Cretaceous fluvial systems.

\subsection{Paleodrainage Reconstruction}

Recently published paleodrainage and sediment routing models in North America during the Early Cretaceous have been based on DZ U-Pb data (Blum and Pecha, 2014; Benyon et al., 2014; 2016). This study interprets paleodrainage patterns for the Morrison, Lytle, and Dakota formations in the Front Range and midcontinent study areas from DZ U-Pb data as well. The new data presented herein is used to examine these previously proposed models for Early Cretaceous paleodrainage and sediment dispersal.

\subsubsection{Morrison Formation Paleodrainage}

$\mathrm{U}-\mathrm{Pb}$ age distributions for all four Morrison samples display a dominant recycled Appalachian-Grenville signature, interpreted to derive from western US Laurentian margin strata that had been incorporated into the Western Cordillera SFTB, but also show a significant contribution from the Western Cordilleran magmatic arc, with a strong $\mathrm{U}-\mathrm{Pb}$ age peak at ca. 160 Ma (Figure 8). However, Morrison samples vary in the relative contributions of arc-sourced 
grains. The two northern samples, DBK-21 and DBK-05 (Horsetooth Reservoir and I-70 Morrison), are closely related to each other in MDS space (see Figure 16A) and have similar arcrelated peaks, as do the two southern samples, DBK-20 and DBK-25 (Penrose and Purgatoire), which are also closely related to each other in MDS space (Figures 8 and 16A). Moreover, the four Morrison samples are generally similar, but there are subtle differences in the presence, absence, or dominance of specific age peaks within the Grenville, Mid-Continent, and Yavapai/Mazatzal age populations. Variations in Morrison KDE plots are reflected in the MDS plot, with DBK-20 and DBK-25 clustering together and DBK-05 and DBK-21 clustering together in the X-Dimension (Figure 16A).

The two clusters identified by MDS are therefore interpreted to represent two different Morrison fluvial systems, each of which drained distinct parts of the SFTB in what is now southern Nevada and Utah. Due to the essentially syndepositional magmatic arc grains in three of the four Morrison samples collected (see discussion of MDAs below), each of the two systems must also have included the Sierra Nevada in southern California, or its ash blanket, as part of the Morrison drainage area (Figure 22). Slight differences in U-Pb age peaks between the two clusters are therefore interpreted to reflect subtle differences in drainage areas from north to south, similar to that found by Pettit et al. (2019) for Late Cretaceous strata in Utah. However, the overall flow direction for the two Morrison systems was essentially the same, west-to-east, and transverse to the general north-to-south orientation of the foreland-basin system.

This interpretation is consistent at a very general level with recent reconstructions based on DZ U-Pb data from the Alberta foreland basin. For example, Raines et al. (2013; see also Quinn et al., 2018) interpret the Late Jurassic fluvial systems of the foredeep in Alberta to have headwaters in the southwestern US and to have routed sediment to the north through the foreland 
basin via an axial or longitudinal system that was parallel to structural grain. However, at a more specific level, these authors argue that sediments were routed to the north through the foredeep of the Sevier foreland basin. The data reported here is inconsistent with that part of the interpretation, as Morrison DZ U-Pb populations from the Colorado Front Range are most similar to the Early Cretaceous DZ U-Pb signatures from the Clearwater and Grand Rapids formations at Cold Lake in the Alberta foreland (Blum and Pecha, 2014). Accordingly, the Morrison of the Colorado Front Range is interpreted to represent two distinct fluvial systems that had headwaters in present-day southern Utah and Nevada and flowed east, transverse to the foreland structural grain to what is now the Colorado Front Range, and then were steered north through the broad backbulge to the eastern margins of the Alberta foreland. In this interpretation, Jurassic deposits in Alberta may have instead been part of Morrison equivalent fluvial systems with headwaters farther to the north along and proximal to the SFTB.

\subsubsection{Lytle Formation Paleodrainage}

All seven Lytle (and age-equivalent) samples from the Colorado Front Range and US midcontinent are dominated by a recycled Appalachian-Grenville population with zircons derived from the magmatic arc, but with no grains that approximate depositional age: these samples are therefore interpreted to record source areas in the Western Cordillera, with sediment derived from the Sierra Nevada and/or its ash blanket and from sedimentary rocks of the western Laurentian margin. The relative contribution of arc-related grains varies between samples, such that the two northernmost samples, DBK-11 and DBK-06 (from Red Canyon, SD and Horsetooth Reservoir) have Western Cordillera grains that represent $\sim 5 \%$ of the total population (Figure 9), and the other four samples from the Colorado Front Range, DBK-03 (Plainview), 
DBK-04, DBK-18, and DBK-23 (I-70 Morrison, I-70 Morrison, Penrose, and Purgatoire, respectively) have similar magmatic arc peaks at ca. $160 \mathrm{Ma}$, with an average arc-related contribution of $11 \%$. The final remaining sample, DBK-16 from Belvidere (SW Kansas), has a magmatic arc signal unlike the other six samples, with a double humped, more muted peak at ca. $160 \mathrm{Ma}$, and arc grains contribute $\sim 9 \%$ of the total.

All seven Lytle (and age-equivalent) samples have the same broad range of $\mathrm{U}-\mathrm{Pb}$ age populations and are generally similar with respect to one another, even though like the Morrison samples, there are subtle differences in the arc-related signatures. Moreover, there are differences between Lytle samples in terms of presence, absence, or dominance of specific age peaks within the Appalachian-Grenville, Mid-Continent, and Yavapai-Mazatzal age populations. Differences in the Lytle KDEs are represented in the MDS plot (Figure 16B), where DBK-06 and DBK-11, the two most northern samples, are nearly identical in the X-Dimension and cluster together with DBK-16, whereas DBK-18, DBK-04, and DBK-23 represent a second cluster. DBK-03, from the Plainview Formation at I-70 Morrison, shares a nearest neighbor with DBK16 (Belvidere, KS) and a second nearest neighbor with DBK-23 (Purgatoire). These clusters are interpreted to represent at least two different Lytle fluvial systems with headwaters in distinct parts of the Western Cordillera magmatic arc and SFTB.

All seven Lytle samples showed significant magmatic arc-sourced populations, hence a paleodrainage and sediment routing model must include the Western Cordilleran magmatic arc or its ash blanket as part of the drainage area. Therefore, Early Cretaceous fluvial systems flowed from west to east (Figure 23) from the Western Cordillera to the foreland basin backbulge and what is now the Colorado Front Range, but likely turned to flow N-NW in the vicinity of the Front Range or slightly to the east. Paleoflow for the Cheyenne (DBK-16) in Kansas and Lakota 
(DBK-11) in South Dakota was likely N-NW (Figure 25), which defines a generally northnorthwest fluvial axis, but both $\mathrm{DZ} \mathrm{U-Pb} \mathrm{samples} \mathrm{have} \mathrm{magmatic} \mathrm{arc} \mathrm{contributions,} \mathrm{indicating} \mathrm{an}$ ultimate source in the Western Cordillera. As was the case for the Morrison, subtle differences between samples in the arc-related age populations, as well as in the other recycled Western Cordillera populations, are interpreted to indicate north-to-south variations in headwaters and drainage area, but the overall general flow direction is the same, from west to east, and then north towards the Alberta foreland basin. This view is supported by the strong similarities between $\mathrm{DZ} \mathrm{U}-\mathrm{Pb}$ age populations of the Cheyenne in Kansas, the Lakota in South Dakota, and the Early Cretaceous McMurray Formation at Cold Lake, Alberta. In an MDS plot of the seven Lytle samples with the two age-equivalent Cold Lake McMurray samples (AOS-7 and AOS-17) included, DBK-11 (Red Canyon, SD) is the nearest neighbor to both AOS samples, and DBK-06 (Horsetooth Reservoir, CO) is the second nearest neighbor to AOS-17) (Figure 26).

\subsubsection{Dakota Formation Paleodrainage}

Dakota samples can be split into two groups based on the presence or absence of Western Cordilleran magmatic arc grains. Dakota samples DBK-09, DBK-12, DBK-13, DBK-14, DBK15, and DBK-17 (Red Canyon, SD, Rapid City, SD, Dakota City, SD, Ashland, NE, Washington, KS, and Salina, KS, respectively) are dominated by primary Appalachian-Grenville populations, lack any magmatic arc signatures, and are therefore interpreted to have been derived from the east (see also Brenner et al., 2000; Ludvigson et al., 2010) (Figure 10). These east-derived Dakota DZ signatures can be used as a proxy for what Lytle-age east-derived signatures would look like, as historically there is little difference in the DZ signature from the Pennsylvanian to

present-day (Eriksson et al., 2003; Finzel, 2014; Blum et al., 2017; Thomas et al., 2017). 
The remaining five samples from the west (DBK-01, DBK-22, DBK-26, DBK-19, and DBK-24) all have the recycled Appalachian-Grenville population plus magmatic arc contributions. Grenville peaks are less pronounced and are therefore interpreted to be the recycled signature and to have been derived from the west. As discussed earlier, the relative contribution of arc-related grains in these west-derived samples generally decreases from north to south. The northernmost samples, DBK-22 and DBK-26 (Horsetooth Reservoir and I-70 Morrison), have strong ca. 100 Ma peaks and minor ca. 160 Ma peaks, representing the two high magmatic flux events that are widely identified in the Sierra Nevada (Figure 5) (Barton, 1990; Armstrong and Ward, 1993; Ducea, 2001; Laskowski et al., 2013). Two of the southern samples, DBK-01 and DBK-19 (John Martin Reservoir and Penrose), have muted ca. 100 Ma and ca. 160 Ma peaks and generally smaller arc-related contributions. The remaining westernderived sample, DBK-24 (Purgatoire), has a ca. 160 Ma peak but no grains from the younger ca. 100 Ma magmatic flux episode. These five samples are also diverse in terms of the presence, absence, or dominance of age peaks from the recycled Appalachian-Grenville, Mid-Continent, and Yavapai-Mazatzal age populations.

The most obvious difference between west- and east-derived samples is the presence or absence of the Western Cordilleran magmatic arc population, but there are other differences as well. Figure 19 illustrates normalized KDE plots for all Dakota samples, with the four samples from the Colorado Front Range plotted with and without the <275 Ma arc population so as to include and eliminate the effect of the arc-related grains. Key west- versus east-derived differences in the >275 Ma populations are as follows: 
- Grenville populations are less dominant relative to east-derived samples, due to dilution by contributions from Mid-Continent, Yavapai-Mazatzal, and Penokean/Trans-Hudson populations.

- The Grenville population is more complex in west-derived samples, with different, more muted peaks, whereas the classical east-derived Grenville has distinct peaks at ca. 1050 and $1150 \mathrm{Ma}$, corresponding to the Ottawan and Shawinigan orogenies, respectively (Heumann et al., 2006).

- The magnitude of specific age populations in west-derived samples varies significantly from those of the eastern-derived samples. This is most notable with the presence of the Peri-Gondwanan peak (ca. 750-500 Ma), which is significant in west-derived samples only.

As might be expected, Dakota samples form distinct west- vs. east-derived clusters in the MDS plot of Figure 16C, based on the presence or absence of the Western Cordilleran magmatic arc population, which supports the interpretations above. Paleocurrents from the west-derived outcrops support general E-NE flow (MacKenzie and Ryan, 1962; Weimer, 1970; Zaleha, 2013), whereas paleocurrents and other data from the east-derived Dakota outcrop belt are consistent with previous inferences of generally east-to-west sediment transport (e.g. Brenner et al. 2000; Ludvigson et al., 2010). These two distinct Dakota clusters are clearly delineated by their DZ U$\mathrm{Pb}$ populations, but the heterogeneities between samples in the same cluster are interpreted to again represent subtle differences in the headwaters or drainage area from north to south within the west- and east-derived systems, which then discharged to the western and eastern margins of the Western Interior Seaway, respectively. 
Last, as discussed above in the results, DBK-01 (John Martin Reservoir) is an outlier when compared to the other samples. Its significance is uncertain and it is therefore not discussed further, although for the sake of completeness DBK-01 data is included in this report.

\subsubsection{Sediment Routing Model}

Recent publications present sediment-routing models for Early Cretaceous paleodrainage in North America using DZ U-Pb data. Blum and Pecha (2014) propose a single model where fluvial systems from the west and southwest US converged with those from the east and southeast US, and then flowed north to the WCSB, whereas Benyon et al. $(2014 ; 2016)$ propose three different scenarios for sediment routing to the WCSB. New data and observations presented herein provide insight on these alternative models. Key observations from DZ U-Pb populations in the Aptian McMurray Formation from the southern part of the WCSB, at Cold Lake, Alberta, in both the Blum and Pecha (2014) and Benyon et al. (2014; 2016) datasets that require explanation or reconciliation are as follows:

- Appalachian-Grenville populations (ca. 300-500 Ma and ca. 950-1250 Ma) dominate McMurray Formation DZ U-Pb signatures.

- McMurray Formation DZ U-Pb populations have a small but consistently present Western Cordilleran magmatic arc signature (ca. <275 Ma).

- McMurray Formation DZ U-Pb populations have a significant Neoproterozoic and Paleozoic Peri-Gondwanan population (ca. 500-700 Ma).

- McMurray Formation DZ U-Pb populations include 15-30\% contributions from MidContinent (ca. 1300-1550 Ma) and Yavapai-Mazatzal (ca. 1600-1800 Ma) sources. 
Blum and Pecha (2014; see also Blum et al., 2017) made additional regional-scale observations that are relevant to the sediment routing model that is being developed here:

- Samples from the McMurray Formation in Alberta are statistically similar to Cenomanian samples from Texas, with the exception of the Western Cordillera populations which do not appear in Gulf of Mexico strata until the Paleocene.

- Cenomanian sediments in Texas were deposited by south-flowing rivers that transported sediment derived from erosion of Pennsylvanian strata in the Ouachita fold and thrust belt of Arkansas and Oklahoma.

New DZ U-Pb data presented in this study are consistent with these observations and are used to interpret convergence of eastern- and western-derived fluvial systems within the Sevier foreland-basin backbulge (Figure 1), then northward sediment transport to the WCSB. Key evidence includes the presence of arc-sourced grains in Lytle samples from the Colorado Front Range, the Cheyenne sample from southwestern Kansas (DBK-16), and the Lakota sample from the Black Hills, SD (DBK-11), as well as the strong east-derived DZ signal (and lack of a Western Cordillera magmatic arc signal) for the six US midcontinent samples in South Dakota, Nebraska, and Kansas, and supporting paleocurrent data (MacKenzie and Poole, 1962; MacKenzie and Ryan, 1962; Weimer, 1970; Karl, 1976; Phillips Jr. et al., 2007; Zaleha, 2013). The Benyon et al. (2014; 2016) models are based on McMurray Formation DZ U-Pb data, but sample locations had a limited geographic extent. Inconsistent aspects of the three sediment-routing scenarios they propose, relative to the observations, are summarized as follows (Figure 2):

1. Model A proposes that Appalachian-Grenville populations were transported directly from the Appalachians to the WCSB (Figure 2A), which assumes transcontinental 
rivers that routed sediment from east-to-west during the Early Cretaceous. Cretaceous strata are no longer present through most of Canada east of the WCSB, but east-to-west transport of Appalachian-derived sediment through the US midcontinent is shown by Finzel (2014). However, unlike the AOS samples, but like the east-derived Dakota samples interpreted here to represent primary Appalachian sources, the Finzel (2014) DZ U-Pb populations are dominated by the AppalachianGrenville population ( $\sim 78 \%$ of the total), lack a consistent Cordilleran arc signature ( $\sim .7 \%$ of the total), include significant ca. $500-700$ Ma Peri-Gondwanan populations ( $2.5 \%$ of the total), and significant Mid-Continent and Yavapai-Mazatzal populations $(<10 \%$ of the total).

2. Model B proposes that Appalachian-Ouachita populations were transported to the southwestern US in the early Mesozoic (Figure 2B), and then recycled from Jurassic eolian sandstones during the Early Cretaceous and routed north (Figure 2B). Dickinson and Gehrels (2008) clearly show that Mesozoic eolian deposits of the Colorado Plateau contain Appalachian-Grenville populations, however, these units would have been buried during deposition of the McMurray by the Jurassic Morrison Formation unless they were exposed in the SFTB farther to the west. These signals are now known to be common throughout Pennsylvanian through mid-Jurassic strata (Gehrels and Pecha, 2014) and comprise the dominant signal in Late Cretaceous strata of the Wasatch Plateau and Book Cliffs in Utah (Pettit et al., 2019).

3. Model C proposes that Appalachian-Grenville populations were routed from the Appalachian-Ouachita Cordillera to western Canada (Figure 2C) prior to the Cretaceous and were then locally recycled into the McMurray Formation. This 
hypothesis is inconsistent with the presence of Cordilleran magmatic arc populations throughout the McMurray and with the size of the McMurray paleochannels (approximately $1 \mathrm{~km}$ wide (Hubbard et al., 2011; Benyon et al., 2016)), which imply something much larger than a local fluvial system.

Moving towards a new routing model, relationships between Cold Lake McMurray AOS samples and DBK samples can be inferred from their relationships in MDS space (Figure 27). Although clear Aptian-age deposits are present in basal Cretaceous outcrops of South Dakota, Nebraska, and Kansas, the DBK samples presented here can be used as a proxy for the eastderived Aptian signatures, as the primary Appalachian-Grenville population has been very consistent through time (Eriksson et al., 2003; Finzel, 2014; Blum et al., 2017; Thomas et al., 2017). Figure 27 shows that the AOS and DBK samples form two distinct clusters, with the west-derived DBK Lytle (and age-equivalent Lakota and Cheyenne) and AOS Cold Lake McMurray samples on the left in blue and the east-derived DBK samples on the right in green. The west-derived cluster shows that AOS-07 and AOS-17 are most closely related to DBK-11 from Red Canyon, SD, which is in turn closely related to DBK-06 from Horsetooth Reservoir and DBK-16 from Belvidere, KS. These relationships support the view that: (a) Lytle and equivalent deposits represent fluvial systems with headwaters in the Cordilleran magmatic arc and the SFTB, which routed sediment to the east, and (b) DBK samples in South Dakota, Nebraska, and Kansas represent fluvial systems with headwaters in the Appalachian-Ouachita Cordillera, which routed sediment to the west. Moreover, from the MDS plot, DBK-16, DBK06, and DBK-11 can be interpreted to represent a south-to-north axial stream that flowed north toward the WCSB and Boreal Sea and deposited the McMurray Formation, as represented by AOS-07 and AOS-17. 
This sediment routing model can be further tested using mixing models (Amidon et al., 2005; Saylor et al., 2013; Sharman and Johnstone, 2017; Saylor et al., 2019), in this case using DZMix, a software package developed by Sundell and Saylor (2017). DZMix unmixes U-Pb age distributions and determines the percent contribution of parent samples to a single daughter sample using an inverse Monte Carlo method. Potential parent source samples are scaled by randomly generated percent contributions that sum to a value of one, and the randomly scaled distributions are summed together to create a single model distribution. The model distribution is then quantitatively compared to the daughter sample using cross-correlation (Saylor et al., 2012), the Kuiper V statistic (Kuiper, 1960) and the Kolmogorov-Smirnov (KS) D statistic (Stephens, 1970). This method is repeated 10,000 times and the top $1 \%$ of model fits are utilized to estimate the mix of potential parent source distributions that best represent the daughter sample U-Pb age distribution (Sundell and Saylor, 2017). It is assumed that all of the parent sources are identified and that they all contribute to the daughter. For this study, the percent contributions interpreted from the Kuiper V and KS D statistics are used to determine the best model distributions and percent contributions, as they both use the difference between two cumulative distribution functions $(\mathrm{CDFs})$. The Kuiper $\mathrm{V}$ statistic is measured as $\mathrm{V}=\max (\mathrm{CDF} 1$ $\left.-\mathrm{CDF}_{2}\right)+\max \left(\mathrm{CDF}_{2}-\mathrm{CDF}_{1}\right)$, whereas the $\mathrm{KS} \mathrm{D}$ statistic is measured as $\mathrm{D}=\max \left(\mid \mathrm{CDF}_{1}-\right.$ $\mathrm{CDF}_{2}$ ) (Sundell and Saylor, 2017). A perfect model fit is inferred when Kuiper $\mathrm{V}=0$ and when $\mathrm{KS} \mathrm{D}=0 . \mathrm{DZMix}$ model results are included in Appendix D.

Based on the MDS plot in Figure 27, DBK-06 was treated as the daughter population in the first model run, which resulted in Kuiper $V=0.1 \pm 0.004$ and $K S \mathrm{D}=0.058 \pm 0.004$, indicating very good fits for both methods. Both the Kuiper V and KS D statistics show that DBK-16 is the highest relative contributor to DBK-06 with $73 \%$ and $60 \%$, respectively (Figures 
29 and 30, Table 8). These results confirm the close statistical relationship between DBK-06 and DBK-16 observed in MDS space (Figures 16B, 26, and 27). The comparison methods differ with respect to which parent sample is the second highest contributor, with the Kuiper V statistic showing DBK-18 (Penrose, CO) at 6\% and the KS D statistic showing DBK-03 (Morrison I-70) at 20\%. DBK-03 is also closely linked to DBK-16 in MDS space (Figures 16B, 26, 27). The remaining percent contributions are all $<5 \%$ for both comparison methods. When grouping the parent samples by their west- vs. east-derived $\mathrm{DZ} \mathrm{U}-\mathrm{Pb}$ signatures, the Kuiper $\mathrm{V}$ and $\mathrm{KS} \mathrm{D}$ statistics show that west-derived samples contribute $92 \%$ and $91 \%$, respectively, and eastderived samples contribute $9 \%$ and $9 \%$, respectively. DBK-06 therefore is dominated by contributions from west-derived fluvial systems but includes a contribution from the east-derived US midcontinent fluvial systems as well.

DBK-11 was the second mixed daughter sample, as it is shown to be most closely related to the AOS samples in MDS space (Figures 16B, 26, and 27) as well as geographically. For this test, DBK-16 was excluded to isolate the clear west-derived vs. east-derived contributions. For DBK-11, V $=0.056 \pm 0.004$ and $\mathrm{D}=0.045 \pm 0.003$, which indicate very good model fits. Both the Kuiper V and KS D statistics found the highest relative contributor to be DBK-06 at $47 \%$ and 47\%, respectively (Figures 31 and 32, Table 9). This confirms the close statistical relationship between DBK-06 and DBK-11 seen in MDS space (Figures 16B, 26, and 27). DBK-11's second highest contributor is DBK-03 (Morrison I-70) for both comparison methods, at 11\% and 19\%, respectively. DBK-03 is close to DBK-11 in MDS space and is also linked to DBK-16 and DBK-06. The third highest most significant contributor is DBK-18 at $8 \%$ using the Kuiper V statistic, and DBK-13 (Dakota City, SD) at 10\% using the KS D statistic: DBK-13 is the fourth highest relative contributor to DBK-11 for the Kuiper V statistic. DBK-13 is east-derived, in a 
separate cluster from DBK-11 in MDS space (Figure 27), and is the closest to DBK-11 in the Xdimension out of the east-derived samples. In aggregate, considering west- vs. east-derived contributions to DBK-11, west-derived samples contribute $78 \%$ and $77 \%$ for the Kuiper V and KS D statistics, respectively, and east-derived samples contribute $22 \%$ and $23 \%$ for the Kuiper V and KS D statistics, respectively. Hence, the relative contributions of west- vs. east-derived sediment are comparable between methods and provide for an interpretation that DBK-11's DZ $\mathrm{U}-\mathrm{Pb}$ signatures dominantly reflect west-derived fluvial systems, but more than $20 \%$ of the population is derived from the east. DBK-11 therefore represents a convergence of eastern and western sourced sediments, and given its close relationship to Cold Lake McMurray Formation samples AOS-07 and AOS-17, can be interpreted to represent the south-to-north oriented axial system that routed sediments to the McMurray Formation of the WCSB. This sediment routing model is summarized in Figure 28.

\subsection{New Maximum Depositional Ages}

New MDAs obtained from Jurassic Morrison and Late Cretaceous Dakota fluvial deposits of the Colorado Front Range approximate true depositional ages (TDAs) and therefore add to the geochronological understanding of these units. However, samples from Early Cretaceous Lytle, Plainview, Cheyenne, and Lakota formations did not produce multiple young grains that enable calculation of MDAs that approximate TDAs, although the Cheyenne and Lakota samples contain individual grains that are consistent with previous age estimates. Moreover, east-derived Dakota samples did not contain zircons with U-Pb ages younger than Pennsylvanian and therefore produced no MDAs that approximate TDA. The presence or absence of MDAs that approximate TDAs for west-derived samples is interpreted to reflect 
whether deposition occurred during periods of high magmatic flux, which occurred during the Late Jurassic (ca. 165-140 Ma) and Cretaceous (ca. 110-80 Ma), or during the intervening Early Cretaceous magmatic lull (ca. 140-110 Ma) (Figure 5) (e.g. Armstrong and Ward, 1993; Ducea, 2001; DeCelles, 2004; DeCelles et al., 2009; May et al., 2013). The absence of MDAs that approximate TDAs for east-derived samples is interpreted to reflect the general lack of postPaleozoic magmatic activity in the eastern US Appalachian source region. One sample from the Woodbury Member of the Dakota Group in Nebraska produced a single young grain with an age of $95.4 \pm 2.3 \mathrm{Ma}$, which supports correlation to the west-derived Dakota and was most likely derived from ashfall (Finzel, 2014).

The Morrison Formation produced three MDAs that approximate TDA and that have MSWD values $\leq 1$, which indicate the grains used for the calculation are consistent with sampling grains of the same true age. The Morrison at Penrose sample (DBK-20) produced the youngest individual grain with a U-Pb age of ca. 145.0 $\pm 3.3 \mathrm{Ma}$ and a calculated MDA of ca. 147.6 \pm 3.1 Ma (n=7, MSWD=0.2) $($ Table 4), whereas MDAs of ca. $148.7 \pm 2.3 \mathrm{Ma}(\mathrm{n}=8$, MSWD=0.1) and ca. $149.6 \pm 2.5 \mathrm{Ma}(\mathrm{n}=7, \mathrm{MSWD}=0.1)$ were obtained from the Morrison at I70 (DBK-05) and Purgatoire (DBK-25), respectively (Figure 17). New MDAs are consistent with, but slightly younger than by 1-2 Myrs, the range of published 40Ar/39Ar dates of sanidines collected in bentonites from the Morrison Formation in Utah, which places deposition at ca. 150$157 \mathrm{Ma}$ (Kowallis et al., 1998; Trujillo and Kowallis, 2015). MDAs from the Colorado Front Range are therefore interpreted to indicate that Morrison deposition continued for 1-2 Myrs longer than previous studies have suggested. For the final Morrison sample, DBK-21 (Horsetooth Reservoir), the youngest grain produced a U-Pb age of ca. 164.1 $\pm 2.6 \mathrm{Ma}$ and a calculated MDA of ca. $165.3 \pm 2.7 \mathrm{Ma}(\mathrm{n}=6, \mathrm{MSWD}=0.3)$. There is no statistical reason to 
reject this MDA, but it is generally recognized that the Morrison Formation is $\sim 12-15$ Myrs younger. It is therefore possible that: (a) this sample did not drain an area with syndepositional volcanism, unlike the Morrison fluvial systems elsewhere in the Front Range, or (b) this MDA approximates TDA for this stratigraphic unit because deep scour by the overlying Lytle Formation fluvial systems was sufficient to completely remove the Morrison Formation at this locality. In the latter case, this MDA would be accepted but pertain to the underlying Sundance Formation.

The regionally significant basal Cretaceous unconformity separates the Morrison from the overlying Lytle Formation in the Colorado Front Range and the Lakota Formation in South Dakota: this unconformity has been interpreted to represent 20 Myrs of time, based on a combination of $40 \mathrm{Ar} / 39 \mathrm{Ar}$ ages from sanidine, dinosaur fossils, and palynomorphs (Kowallis et al., 1998; Currie, 1998; DeCelles, 2004). The Lytle and Lakota formations have therefore been interpreted to be Barremian to Aptian in age (May et al., 1995). The Cheyenne Formation in Kansas also rests on the sub-Cretaceous unconformity, but underlying rocks are Permian in age (Swineford and Williams, 1945). The Lytle Formation produced no U-Pb ages < ca. $145 \mathrm{Ma}$, whereas the Lakota produced a single $\mathrm{U}-\mathrm{Pb}$ age of ca. 134.6 $\pm 1.7 \mathrm{Ma}$ and the Cheyenne produced a single $\mathrm{U}-\mathrm{Pb}$ age of ca. $122.9 \pm 2.1 \mathrm{Ma}$. While these two $\mathrm{U}-\mathrm{Pb}$ ages from the Lakota and Cheyenne formations are consistent with deposition during the Barremian and Aptian, the overall general paucity of syndepositional volcanogenic zircons is interpreted to represent the Early Cretaceous magmatic lull (Armstrong and Ward, 1993; Ducea, 2001; DeCelles, 2004; May et al., 2013). The Plainview Formation of the Colorado Front Range is also traditionally interpreted to be late Aptian to mid-Albian in age (Dolson and Muller, 1994; Willis, 1997): the 
single Plainview DZ sample from I-70 Morrison contained no U-Pb ages < ca. $145 \mathrm{Ma}$, which is also interpreted to reflect the same magmatic lull.

The Dakota Formation of the Colorado Front Range has been considered to be late Albian to Cenomanian in age, with the top of the unit placed at ca. $95 \mathrm{Ma}$ based on faunal assemblages (Weimer, 1984). Dakota strata of Kansas and Nebraska are also viewed to be Albian to Cenomanian in age based on pollen assemblages and other biostratigraphic data (Ludvigson et al., 2010), and DZ U-Pb analyses by Finzel (2014) produced a single U-Pb age of ca. 95 Ma from a Dakota sample in Iowa. For the present study, four of five samples from the west-derived Dakota fluvial deposits of the Front Range produced MDAs that approximate TDA, and which have MSWD values $\leq 1$. The youngest individual grain was obtained from DBK-01 (John Martin Reservoir), with a U-Pb age of ca. 96.2 $\pm 2.2 \mathrm{Ma}$ and an MDA of 96.3 $\pm 4.3 \mathrm{Ma}$ $(\mathrm{n}=2, \mathrm{MSWD}=0.01)($ Table 4). The other three samples, DBK-19 (Penrose), DBK-26 (I-70 Morrison), and DBK-22 (Horsetooth) produce MDAs of ca. 98.1 $\pm 1.9 \mathrm{Ma}(\mathrm{n}=7, \mathrm{MSWD}=0.04)$, ca. 99.2 $\pm 1.7 \mathrm{Ma}(\mathrm{n}=12, \mathrm{MSWD}=0.3)$, and ca. $99.6 \pm 1.6 \mathrm{Ma}(\mathrm{n}=5, \mathrm{MSWD}=0.1)$, respectively (Figure 18). These MDAs are consistent with published age estimates of ca. 95 Ma for the top of the Dakota in the Front Range from faunal assemblages (Weimer, 1984), and with DZ U-Pb ages of ca. 100-101 Ma from the Dakota of Big Horn Basin in Wyoming (May et al., 2013). The final remaining western-derived Dakota sample, DBK-24 from Purgatoire, produced youngest grains ca. 150-151 Ma, which are too old for stratigraphic context and do not approximate TDA. It seems likely the Dakota fluvial system responsible for deposition at Purgatoire had headwaters in the Western Cordillera SFTB, but not proximal to the Late Cretaceous magmatic arc or its ash blanket. 
Comparison of new MDAs presented here to age-equivalent units elsewhere in the Sevier foreland basin would be useful. May et al. (2013) present DZ U-Pb data from the Cloverly Formation in the Bighorn Basin, which is traditionally viewed as Aptian to early Albian in age, or as young as Valanginian (D'Emic et al., 2019): however, two of the Cloverly samples in May et al. (2013) contain no grains younger than Jurassic in age, similar to the Lytle in the Colorado Front Range, whereas the other two contain Albian-age grains. One of these samples contains 10 grains with $\mathrm{U}-\mathrm{Pb}$ ages between 110-108 Ma, which suggests either the Cloverly at those locations is younger than the Lytle, or this sample location does not represent the Cloverly. Additionally, Painter et al. (2014) examined a number of Mesozoic units in the Sevier foreland basin from South Dakota to Utah, and Ludvigson et al. (2010) did the same in Utah. This allows for basic regional correlations based on $\mathrm{U}-\mathrm{Pb}$ data. These previously published $\mathrm{DZ} \mathrm{U}-\mathrm{Pb}$ signatures match those of the new Colorado Front Range samples included herein with similar recycled Appalachian-Grenville populations plus Cordilleran magmatic arc grains. 


\section{Conclusions and Future Work}

This thesis presents a DZ U-Pb record of 22 samples from the Late Jurassic Morrison through Cenomanian Dakota Group strata of the Colorado Front Range and the US midcontinent. Alluvial architecture and sedimentological observations, statistical comparisons between samples, and quantitative mixing models were used to test and refine previously published models for Early Cretaceous paleodrainage and sediment routing patterns. MDAs from the Morrison and Dakota fluvial deposits were used to improve understanding of the timing of deposition. Key interpretations from this study are summarized as follows:

- Observations of alluvial architecture and sedimentological characteristics point to differences in the types of rivers represented by the Morrison, Lytle, Plainview, and Dakota formations.

○ The Morrison Formation is interpreted to have been deposited by a meandering fluvial system on an aggrading floodplain.

- The Lytle Formation is interpreted to represent a mixed bedrock-alluvial valley system, where the river was confined within a broad valley and incised into the subjacent bedrock of the Morrison Formation.

○ The Plainview Formation is interpreted to consist of mixed fluvial and near shore marine environments, deposited within the Lytle bedrock valleys.

○ The upper Dakota Formation is interpreted to represent fluvial systems that cut across delta plains represented by the lower Dakota during regression.

- Statistical comparisons of DZ U-Pb populations show clear differences between westderived Cretaceous Lytle and Dakota fluvial deposits of the Colorado Front Range, southwest Kansas, and the Black Hills of South Dakota vs. east-derived Dakota fluvial deposits from farther east in South Dakota, Nebraska, and Kansas. Samples fall into two 
clusters, which are primarily based on the presence or absence of Western Cordilleran magmatic arc grains. Moreover, east-derived samples are dominated by primary Appalachian-Grenville populations from the Appalachian-Ouachita Cordillera, whereas west-derived samples are dominated by recycled Appalachian-Grenville populations derived from the Sevier fold and thrust belt, with contributions from the Mesozoic magmatic arc, as well as Mid-Continent and Yavapai-Mazatzal source terrains.

- Mixing models that estimate contributions from parent populations to a mixed daughter were used to provide a new reconstruction of paleodrainage and sediment routing that features convergence of east- and west-derived systems in the broad backbulge located in the US midcontinent, followed by flow to the north toward the Western Canada Sedimentary Basin and Boreal Sea. The south-to-north fluvial systems inferred here represent the axial feeder system that ultimately deposited the Early Cretaceous McMurray Formation of the Alberta Oil Sands. Mixing models suggest $77-78 \%$ of the DZ U-Pb signal for the farthest north DBK sample in South Dakota (DBK-11) was derived from the western tributary network, whereas $22-23 \%$ was derived from the east and the AppalachianOuachita Cordillera.

- Seven new maximum depositional ages improve the geochronological framework for the Late Jurassic and Cenomanian in the Colorado Front Range. The Morrison Formation in Colorado produced three MDAs that are consistent with, but slightly younger than, ages previously established in Utah. These MDAs are interpreted to indicate that Morrison deposition continued for 1-2 Myrs longer than previously recognized. The Dakota Formation in Colorado produced four MDAs that are consistent with published age estimates for the Front Range and provide the first U-Pb ages for the Dakota in Colorado. 
A number of topics deserve further study. Future work includes resolving stratigraphic inconsistencies between age-equivalent units, specifically in the Bighorn Basin. This will allow for broader regional correlations based on the $\mathrm{U}-\mathrm{Pb}$ data and possible further refinement of the general paleodrainage model. Additionally, investigation into the results from DBK-01 is necessary in order to determine its significance within the Dakota system and the sediment-routing model as a whole. Incorporation of well log data from the Denver Basin in a transect from north to south, parallel to the Colorado Front Range, would supplement this study well.

This study shows that understanding alluvial architectures of formations is important when considering how different fluvial styles are represented within a source-to-sink framework. Through the use of DZ U-Pb provenance and geochronological techniques, inferred ancient sediment-routing patterns have been supported and falsified, and MDAs have provided improvements to geochronological frameworks for the time period and units studied herein. Ultimately, DZ U-Pb analyses are a powerful tool for assessment of fluvial system dynamics and broader paleo-depositional patterns. 


\section{References}

Altschuld, K.R., 1980, Stratigraphy and depositional environments of the Dakota Group, Cañon City area, Colorado, M.S. Thesis, Colorado School of Mines, 179 p.

Amidon, W.H., Burbank, D.W., and Gehrels, G.E., 2005, Construction of detrital mineral populations: insights from mixing of $\mathrm{U}-\mathrm{Pb}$ zircon ages in Himalayan rivers: Basin Res. v. 17 , p. $463-485$.

Andersen, T., 2005, Detrital zircons as tracers of sedimentary provenance: limiting conditions from statistics and numerical simulation: Chemical Geology, v. 216, i. 3-4, p. 249-270.

Armstrong, R.L., and Ward, P.L., 1993, Late Triassic to Earliest Eocene magmatism in the North American Cordillera: implications for the Western Interior Basin, in Caldwell, W.G.E., and Kauffman, E.G., eds., Evolution of the Western Interior Basin: Geological Association of Canada, Special Paper 39, p. 49-72.

Barton, M.D., 1990, Cretaceous magmatism, metamorphism, and metallogeny in the east-central Great Basin, in Anderson, J.L., ed., The Nature and Origin of Cordilleran Magmatism: Geological Society of America Memoir 174, p. 283-302, GSA, Boulder, CO.

Becker, T.P., Thomas, W.A., Samson, S.D., and Gehrels, G.E., 2005, Detrital zircon evidence of Laurentian crustal dominance in the lower Pennsylvanian deposits of the Alleghanian clastic wedge in eastern North America: Sedimentary Geology, v. 182, p. 59-86.

Benyon, C., Leier, A., Leckie, D.A., Webb, A., Hubbard, S.M., and Gehrels, G., Provenance of the Cretaceous Athabasca Oil Sands, Canada: Implications for Continental-Scale Sediment Transport: Journal of Sedimentary Research, v. 84, p. 136-143.

Benyon, C., Leier, A., Leckie, D., Hubbard, S., and Gehrels, G., 2016, Sandstone provenance and insights into the paleogeography of the McMurray Formation from detrital zircon geochronology, Athabasca Oil Sands, Canada: AAPG Bulletin, v. 100, p. 269-287.

Berg, R.R., 1968, Point-bar origin of Fall River sandstone reservoirs, northeastern Wyoming: American Association of Petroleum Geology Bulletin No. 52, p. 2116-2122.

Black, L.P., Kamo, S.L., Allen, C.M., Davis, D.W., Aleinikoff, J.N., Valley, J.W., Mundil, R., Campbell, I.H., Korsch, R.J., Williams, I.S., and Foudoulis, C., 2004, Improved ${ }_{206} \mathrm{~Pb} / 238 \mathrm{U}$ microprobe geochronology by the monitoring of a trace-element-related matrix effect; SHRIMP, ID-TIMS, ELA-ICP-MS and oxygen isotope documentation for a series of zircon standards, Chemical Geology, v. 205, i. 1-2, pp. 115-140.

Blum, M., Martin, J., Milliken, K., and Garvin, M., 2013, Paleovalley systems: Insights from Quaternary analogs and experiments: Earth-Science Reviews, v. 116, p. 128-169.

Blum, M.D. and Pecha, M., 2014, Mid-Cretaceous to Paleocene North American drainage reorganization from detrital zircons: Geology, v. 42, p. 607-610. 
Blum, M.D., Milliken, K.T., Pecha, M.A., Snedden, J.W., Frederick, B.C., and Galloway, W.E., 2017, Detrital-zircon records of Cenomanian, Paleocene, and Oligocene Gulf of Mexico drainage integration and sediment routing: Implications for scales of basin-floor fans: Geosphere, v. 13, p. 1-37.

Bolyard, D.W., and McGregor, A.A., 1966, Stratigraphy and petroleum potential of Lower Cretaceous Inyan Kara Group in northeastern Wyoming, southeastern Montana, and western South Dakota: AAPG Bulletin, v. 50, no. 10, p. 2221-2244.

Borg, I., and Groenen., P.J., 2005, Modern Multidimensional Scaling: Theory and Applications. Springer.

Brenner, R.L., Ludvigson, G.A., Witzke, B.J., Zawistoski, A.N., Kvale, E.P., Ravn, R.L., and Joeckel, R.M., 2000, Late Albian Kiowa-Skull Creek Marine Transgression, Lower Dakota Formation, Eastern Margin of Western Interior Seaway, U.S.A.: Journal of Sedimentary Research, v. 70, no. 4, p. 868-878.

Burchfiel, B.C., and Davis, G.A., 1975, Nature and controls on Cordilleran orogenesis, western US.:extensions of an earlier synthesis: American Journal of Science, v. 275A, p. 363-396.

Campbell, C.V., and Oaks, R.Q., 1973, Estuarine sandstone filling tidal scours, Lower Cretaceous Fall River Formation, Wyoming: Journal of Sedimentary Petrology, v. 43, no. 3, p. 765-778.

Carpenter, K., 2014, There the sea meets the land - the unresolved Dakota problem in Utah, in MacLean, J.S., Biek, R.F., and Huntoon, J.E., eds., Geology of Utah's Far South: Utah Geological Association Publication 43, p. 357-372.

Currie, B.S., 1998, Upper Jurassic-Lower Cretaceous Morrison and Cedar Mountain Formations, NE Utah-NW Colorado: relationships between nonmarine deposition and early cordilleran foreland-basin development: Journal of Sedimentary Research, v. 68, no. 4, p. 632-652.

Dahlstrom, D.J., and Fox, J.E., 1995, Fluvial architecture of the Lower Cretaceous Lakota Formation, southwestern flank of the Black Hills uplift, South Dakota, in U.S. Geological Survey Bulletin 1917, Evolution of Sedimentary Basins-Powder River Basin, p. 1-19.

DeCelles, P.G., Gehrels, G.E., Quade, LaReau, B., and Spurlin, M., 2000, Tectonic implications of $\mathrm{U}-\mathrm{Pb}$ zircon ages of the Himalayan orogenic belt in Nepal: Science, v. 288, no. 5465, p. 497-499.

DeCelles, P.G., 2004, Late Jurassic to Eocene evolution of the Cordilleran thrust belt and foreland basin system, western U.S.A.: American Journal of Science, v. 304, p. 105-168.

DeCelles, P.G., and Currie, B.S., 1996, Long-term sediment accumulation in the Middle Jurassic-early Eocene Cordilleran retroarc foreland-basin system: Geology, v. 24, no. 7, p. 591-594.

DeCelles, P.G., Ducea, M.N., Kapp, P., and Zandt, G., 2009, Cyclicity in Cordilleran orogenic 
systems: Nature Geoscience, v. 2, p. 251-257.

D’Emic, D.D., Foreman, B.Z., Jud, N.A., Britt, B.B., Schmitz, M., and Crowley, J.L., Chronostratigraphic revision of the Cloverly Formation (Lower Cretaceous, Western Interior, USA): Bulletin of the Peabody Museum of Natural History, v. 60, p. 3-40.

Dickinson, W.R., and Gehrels, G.E., 2008, U-Pb ages of DZs in relation to paleogeography: Triassic paleodrainage networks and sediment dispersal across southwest Laurentia: Journal of Sedimentary Research, v. 78, p. 745-764.

Dickinson, W.R., and Gehrels, G.E., 2009, Use of U-Pb ages of detrital zircons to infer maximum depositional ages of strata: a test against a Colorado Plateau Mesozoic database: Earth and Planetary Science Letters, v. 288, p. 115-125.

Dickinson, W.R., and Gehrels, G.E., 2010, Insights into North American paleogeography and paleotectonics from U-Pb ages of detrital zircons in Mesozoic strata of the Colorado Plateau, USA, International Journal of Earth Sciences, v. 99, no. 6, p. 1247-1265.

Dodson, M.H., Compston, W., Williams, I.S., and Wilson, J.F., 1988, A search for ancient detrital zircons in Zimbabwean sediments: Journal of the Geological Society, London, v. 145, p. 977-983.

Dolson, J.C., Muller, D., Evetts, M.J., and Stein, J.A., 1991, Regional paleotopographic trends and production, Muddy Sandstone (Lower Cretaceous), Central and Northern Rocky Mountains (1): AAPG Bulletin, v. 75, no. 3, p. 409-435.

Dolson, J.C., and Weimer, R.J., 1992, Examples of unconformities of related systems tracts, Cretaceous through Precambrian strata, Front Range (Colorado) and Wyoming, in Flores, R.M., ed., Field Trip Guidebook, Mesozoic of the Western Interior, SEPM (Society for Sedimentary Geology) 1992 Theme Meeting, p. 55-74.

Dolson, J.C., and Muller, D.S., 1994, Stratigraphic evolution of the Lower Cretaceous Dakota Group, Western Interior, USA, in Caputo, M.V., Peterson, J.A., and Franczyk, K.J., eds., Mesozoic Systems of the Rocky Mountain Region, USA, Rocky Mountain Section of SEPM, p. 441-456.

Ducea, M., 2001, The California arc: thick granitic batholiths, exlogitic residues, lithosphericscale thrusting and magmatic flare-ups: GSA Today, v. 11, no. 11, p. 4-10.

Eriksson, K.A., Campbell, I.H., Palin, J.M., and Allen, C.M., 2003, Predominance of Grenvillian magmatism recorded in detrital zircons from modern Appalachian Rivers: Journal of Geology, v. 111, p. 707-717.

Erslev, E.A., 1993, Thrusts, back-thrusts and detachment of Rocky Mountain foreland arches, in Schmidt, C.J., Chase, R.B., and Erslev, E.A., editors, Laramide basement deformation in the Rocky Mountain foreland of the western United States: Geological Society of America Special Paper 280, p. 339-358. 
Fedo, C.M., Sircombe, K.N., and Rainbird, R.H., 2003, Detrital zircon analysis of the sedimentary record: Reviews in Mineralogy and Geochemistry, v. 53, no. 1, p. 277-303.

Finzel, E.S., 2014, Detrital zircons from Cretaceous midcontinent strata reveal an Appalachian Mountains-Cordilleran foreland basin connection: Lithosphere, v.6, no. 5, p. 378-382.

Franks, P.C., 1975, Paralic to fluvial record of an Early Cretaceous marine transgressionLongford Member, Kiowa Formation, north-central Kansas: Kansas Geological Survey, Bulletin 219, 55 p.

Gehrels, G.E., 2000, Introduction to detrital zircon studies of Paleozoic and Triassic strata in western Nevada and northern California, in Soreghan, M.J., and Gehrels, G.E., eds., Paleozoic and Triassic Paleogeography and Tectonics of Western Nevada and Northern California: Geological Society of America, Special Paper 347, p. 1-18.

Gehrels, G.E., 2012, Detrital zircon U-Pb geochronology: current methods and new opportunities, in Busby, C., and Azor, A.A., eds., Tectonics of Sedimentary Basins, Recent Advances, p. 47-62.

Gehrels, G.E., 2014, Detrital zircon U-Pb geochronology applied to tectonics: Annual Review of Earth and Planetary Sciences, v. 42, p. 127-149.

Gehrels, G.E., Valencia, V., and Ruiz, J., 2008, Enhanced precision, accuracy, efficiency, and spatial resolution of $\mathrm{U}-\mathrm{Pb}$ ages by laser ablation-multicollector-inductively coupled plasma mass spectrometry: Geochemistry, Geophysics, Geosystems, v. 9, Q03017, doi:10.1029/2007GC001805.

Gehrels, G.E., Blakey, R., Karlstrom, K.E., Timmons, J.M., Dickinson, W.R., and Pecha, M., 2011, Detrital zircon U-Pb geochronology of Paleozoic strata in the Grand Canyon, Arizona: Lithosphere, v. 3, p. 183-200.

Gehrels, G.E., and Pecha, M., 2014, Detrital zircon U-Pb geochronology and Hf isotope geochemistry of Paleozoic and Triassic passive margin strata of western North America: Geosphere, v. 10, no. 1, p. 49-65.

Greenhalgh, B.W., 2006, New U-Pb age control for the Lower Cedar Mountain Formation and an evaluation of the Morrison Formation/Cedar Mountain Formation boundary, Utah: Geological Society of America Rocky Mountain Section Annual Meeting, Gunnison, Abstracts with Programs, vol. 38, no. 6, p. 7.

Gries, J.P., 1962, Lower Cretaceous stratigraphy of South Dakota and the eastern edge of the Powder River Basin, in Symposium on Early Cretaceous Rocks of Wyoming and Adjacent Areas; Wyoming Geological Association 17th Annual Field Conference Guidebook, p. $163-172$.

Gustason, E.R., and Kauffman, E.G., 1985, The Dakota Group and the Kiowa-Skull Creek cyclothem in the Cañon City-Pueblo Area, Colorado, Society of Economic Paleontologists and Mineralogists, mid-year meeting, Golden, Guidebook no. 4, p. 72-89. 
Haerter, J.P., 1990, Sequence stratigraphy of the Fall River Sandstone, northern Powder River Basin, Wyoming and Montana, M.S. Thesis, Colorado State University, Fort Collins, CO.

Hamilton, V., 1994, Sequence stratigraphy of Cretaceous Albian and Cenomanian strata in Kansas, in Shurr, G.W., Ludvigson, G.A., and Hammond, R.H., eds., Perspectives on the Eastern Margin of the Cretaceous Western Interior Basin: Geological Society of America, Special Paper 287, p. 79-96.

Hein, F.J., Dolby, G., and Fairgrieve, B., 2013, A regional geologic framework for the Athabasca oil sands, northeastern Alberta, Canada, in Hein, F.J., Leckie, D., Larter, S., and Suter, J.R., eds., Heavy-oil and oil-sand petroleum systems in Alberta and beyond: AAPG Studies in Geology 64, p. 207-250.

Heller, P.L., and Liu, L., 2016, Dynamic topography and vertical motion of the U.S. Rocky Mountain region prior to and during the Laramide orogeny: GSA Bulletin, v. 128, no. 5/6, p. 973-988.

Heumann, M.J., Bickford, M.E., Hill, B.M., McLelland, J.M., Sellack, B.W., and Jercinovic, M.J., 2006, Timing of anatexis in metapelites from the Adirondack lowlands and southern highlands: a manifestation of the Shawinigan orogeny and subsequent anorthositemangerite-charnockite-granite magmatism: GSA Bulletin, v. 118, no. 11/12, p. 1283-1298.

Holbrook, J., and Ethridge, F.G., 1996, Sequence stratigraphy of the Dakota Group and equivalents from north-central Colorado to northeastern New Mexico: down-dip variations in sequence anatomy: Geologic Excursions to the Rocky Mountains and Beyond, 1996 GSA Guidebook, Colorado Geological Survey Special Publication 44, 44 p.

Hubbard, S.M., Smith, D.G., Neilsen, H., Leckie, D.A., Fustic, M., Spencer, R.J., and Bloom, L., 2011, Seismic geomorphology and sedimentology of a tidally influenced river deposit, Lower Cretaceous Athabasca Oil Sands, Alberta, Canada: AAPG Bulletin, v. 95, p. $1123-1145$.

Joeckel, R.M., Ludvigson, G.A., Möller, A., Hotton, C.L., Suarez, M.B., Suarez, C.A., Sames, B., Kirkland, J.I., and Hendrix, B., 2019, Chronostratigraphy and terrestrial palaeoclimatology of Berriasian-Hauterivian strata of the Cedar Mountain Formation, Utah, USA: Geological Society of London Special Publication 498.

Karl, H.A., 1976, Depositional history of Dakota Formation (Cretaceous) sandstones, southeastern Nebraska: Journal of Sedimentary Petrology, v. 46, no. 1, p. 124-131.

Kauffman, E.G., and Caldwell, W.G.E., 1993, The Western Interior Basin in space and time, in Caldwell, W.G.E., and Kauffman, E.G., eds., Evolution of the Western Interior Basin, Geological Association Canada, Special Paper 39, p. 1-30.

Kirkwood, S.G., 1977, Stratigraphy and petroleum potential of the Cedar Mountain and Dakota Formations, northwestern Colorado: M.S. Thesis, Colorado School of Mines, 193 p. 
Kowallis, B.J., Christiansen, E.H., Deino, A.L., Peterson, F., Turner, C.E., Kunk, M.J., and Obradovich, J.D., 1998, The age of the Morrison Formation: Modern Geology, v. 22, p. 235-260.

Kuiper, N.H., 1960, Tests concerning random points on a circle: Indagationes Mathematicae (Proceedings), v. 63, p. 38-47.

Kvale, E.P., 1986, Paleoenvironments and tectonic significance of the Upper Jurassic Morrison/Lower Cretaceous Cloverly formations, Bighorn Basin, Wyoming, PhD Dissertation, Iowa State University, 201 p.

Kvale, E.P., and Vondra, C.F., 1993, Effects of relative sea-level changes and local tectonics on a Lower Cretaceous fluvial to transitional marine sequence, Bighorn Basin, Wyoming, USA, in Marzo, M., Puigdefabrgas, C., eds., Alluvial Sedimentation, International Association of Sedimentology Special Publication, v. 17, p. 383-399.

Laskowski, R.L., Cox, R., Mapes, R.W., and Coleman, D.S., 2013, Hydrodynamic fractionation of zircon age populations: Geological Society of America, Bulletin, v. 123, no. 1-2, p. $1-22$.

Licht, A., Reisberg, L., France-Lanord, C., Soe, A.C., and Jaegar, J.J., Cenozoic evolution of the central Myanmar drainage basin: insights from sediment provenance in the Minbu subbasin: Basin Research, v. 28, no. 2, p. 237-251.

Link, P.K., Christie-Blick, N., Devlin, W.J., Elston, D.P., Horodyski, R.J., Levy, M., Miller, J.M.G., Pearson, R.C., Prave, A., Stewart, J.H., Winston., D., Wright, L.A., and Wrucke, C.T., 1993, Middle and late Proterozoic stratified rocks of the western US Cordillera, Colorado Plateau, and Basin and Range Province, in Reed, J.C., et al., eds., Precambrian; Conterminous U.S., Boulder, CO, Geological Society of America, The Geology of North America, v. C-2, p. 463-595.

Liu, S.F., Nummedal, D., and Liu, L., 2011, Migration of dynamic subsidence across the Late Cretaceous United States Western Interior Basin in response to Farallon plate subduction: Geology, v. 39, p. 555-558.

Long, C.S. Jr., 1966, Basal Cretaceous strata, southeastern Colorado: Ph.D. Thesis, University of Colorado, Boulder, $479 \mathrm{pp}$.

Ludvigson, G.A., Joeckel, R.M., González, L.A., Gulbranson, E.L., Rasbury, E.T., Hunt, G.J., Kirkland, J.I., and Madsen, S., 2010, Correlation of Aptian-Albian carbon isotope excursions in continental strata of the Cretaceous foreland basin, eastern Utah, U.S.A., Journal of Sedimentary Research, v. 80, no. 11, p. 955-974.

Ludvigson, G.A., Möller, A., Joeckel, R.M., Blum, M.D., and McLean, N., 2017, Uranium-lead ages of Cretaceous (Albian-Cenomanian) strata from the Rose Creek Escarpment of the cratonic margin of the Western Interior Basin: Geological Society of America Abstracts with Programs, v. 49, no. 6. 
MacKenzie, F.T., and Ryan, J.D., 1962, Cloverly-Lakota and Fall River paleocurrents in the Wyoming Rockies, in Symposium on Early Cretaceous Rocks of Wyoming and Adjacent Areas; Wyoming Geological Association 17th Annual Field Conference Guidebook, p. 44-61.

MacKenzie, D.B., and Poole, D.M., 1962, Provenance of Dakota Group sandstones of the Western Interior, in Symposium on Early Cretaceous Rocks of Wyoming and Adjacent Areas; Wyoming Geological Association 17th Annual Field Conference Guidebook, p. $62-71$.

MacKenzie, D.B., 1963, Dakota Group of west flank of Denver Basin, in Geology of the northern Denver Basin and adjacent uplifts: Rocky Mountain Association of Geologists 14th Annual Field Conference Guidebook, p. 135-149.

MacKenzie, D.B., 1965, Depositional environments of Muddy Sandstone, western Denver Basin, Colorado: American Association of Petroleum Geologists Bulletin, v. 49, no. 2, p. 186-206.

MacKenzie, D.B., 1971, Post-Lytle Dakota Group on west flank of Denver Basin, Colorado: The Mountain Geologist, v. 9, p. 269-277.

May, M.T., Furer, L.C., Kvale, E.P., and Suttner, L.J., 1995, Chronostratigraphy and tectonic significance of Lower Cretaceous conglomerates in the foreland of central Wyoming: Stratigraphic Evolution of Foreland Basins, SEPM Special Pub. No. 52, p. 97-100.

May, S.R., Gray, G.G., Summa, L.L., Stewart, N.R., Gehrels, G.E., and Pecha, M.E., 2013, Detrital zircon geochronology from the Bighorn Basin, Wyoming, USA: implications for tectonostratigraphic evolution and paleogeography: Geological Society of America Bulletin, v. 123, p. 1403-1422.

McLaughlin, T.G., 1954, Geology and ground-water resources of Baca County, Colorado: U.S. Geological Survey Water-Supply Paper 1256.

Merriam, D.F., 1963, The geologic history of Kansas: Kansas Geological Survey, Bulletin 162, 317 p.

Miller, D.N., 1962, Patterns of barrier bar sedimentation and its similarity to the Lower Cretaceous Fall River stratigraphy, in Symposium on Early Cretaceous Rocks of Wyoming and Adjacent Areas; Wyoming Geological Association 17th Annual Field Conference Guidebook, p. 232-247.

Milliken, K.T., Blum, M.D., Snedden, J.W., and Galloway, W.E., 2018, Application of fluvial scaling relationships to reconstruct drainage-basin evolution and sediment routing for the Cretaceous and Paleocene of the Gulf of Mexico: Geosphere, v. 14, no. 2, p. 749-767.

Milliman, J.D., and Syvitski, J.P.M., 1992, Geomorphic/tectonic control of sediment discharge to the ocean: the importance of small mountainous rivers: The Journal of Geology, v. 100, no. 5 , p. 525-544. 
Moberly, R.J., 1960, Morrison, Cloverly, and Sykes Mountain Formations, northern Bighorn Basin, Wyoming and Montana: GSA Bulletin v. 71, no. 8, p. 1137-1176.

Moore, R.C., Frye, J.C., Jewett, J.M., Lee, W., and O'Connor, H.G., The Kansas Rock Column: Kansas Geological Survey, Bulletin 89.

Ostrom, J.H., 1970, Stratigraphy and Paleontology of the Cloverly Formation (Lower Cretaceous) of the Bighorn Basin Area, Wyoming and Montana: Peabody Museum of Natural History Bulletin 35, 234 p.

Paces, J.B., and Miller, J.D., 1993, Precise U-Pb ages of Duluth Complex and related mafic intrusions, northeastern Minnesota: Geochronological insights to physical, petrogenetic, paleomagnetic, and tectonomagmatic processes associated with the 1.1 GA Midcontinent Rift System: Journal of Geophysical Research, v. 98, no. B8, p. 13,997-14,013.

Painter, C.S., Carrapa, B., DeCelles, P.G., Gehrels, G.E., and Thomson, S.N., 2014, Exhumation of the North American Cordillera revealed by multi-dating of Upper Jurassic-Upper Cretaceous foreland basin deposits, GSA Bulletin, v. 126, no. 11/12, p. 1439-1464.

Pang, M., and Nummedal, D., 1995, Flexural subsidence and basement tectonics of the Cretaceous Western Interior basin, U.S.: Geology, v. 23, no. 2, p. 173-176.

Park., H., Barbeau Jr., D.L., Rickenbaker, A., Bachmann-Krug, D., and Gehrels, G.E., 2010, Application of foreland basin detrital-zircon geochronology to the reconstruction of the southern and central Appalachian orogen: The Journal of Geology, v. 118, p. 23-44.

Peterson, F., and Turner, C.E., 1998, Stratigraphy of the Talston Creek and Morrison Formations (Upper Jurassic) near Denver, Colorado: Modern Geology, v. 22, p. 3-38.

Pettit, B.S., Blum, M., Pecha, M., McLean, N., Bartschi, N.C., and Saylot, J.E., 2019, Detritalzircon $\mathrm{U}-\mathrm{Pb}$ paleodrainage reconstruction and geochronology of the Campanian Blackhawk-Castlegate succession, Wasatch Plateau and Book Cliffs, Utah, U.S.A., Journal of Sedimentary Research, v. 89, no. 4, p. 273-292.

Phillips Jr., P.L., Ludvigson, G.A., Joeckel, R.M., Gonzalez, L.A., Brenner, R.L., and Witzke, B.J., 2007, Sequence stratigraphic controls on synsedimentary cementation and preservation of dinosaur tracks: Example from the lower Cretaceous (Upper Albian) Dakota Formation, Southeastern Nebraska, USA: Palaeogeography, Palaeoclimatology, Palaeoecology v. 246, p. 367-389.

Pullen, A., Ibanez-Mejia, M., Gehrels, G.E., Ibanez-Mejia, J.C., and Pecha, M., 2014, What happens when $n=1000$ ? Creating large-n geochronological datasets with LA-ICP-MS for geologic investigations: Journal of Analytical Atomic Spectrometry, v. 29, p. 971-980.

Quinn, G.M., Hubbard, S.M., Putnam, P.E., Matthews, W.A., Daniels, B.G., and Guest, B., 2018, A Late Jurassic to Early Cretaceous record of orogenic wedge evolution in the Western Interior basin, USA and Canada: Geosphere, v. 14, no. 3, p. 1187-1206. 
Rainbird, R.H., Hamilton, M.A., and Young, G.M., 2001, Detrital zircon geochronology and provenance of the Torridonian, NW Scotland: Journal of the Geological Society, London, v. 158, p. 15-27.

Raines, M.K., Hubbard, S.M., Kukulski, R.B., Leier, A.L., and Gehrels, G.E., 2013, Sediment dispersal in an evolving foreland: Detrital zircon geochronology from Upper Jurassic and lowermost Cretaceous strata, Alberta Basin, Canada: Geological Society of America Bulletin, v. 125, p. 741-755.

Rasmussen, D.L., Jump, C.J., and Wallace, K.A., 1985, Deltaic systems in the Early Cretaceous Fall River Formation, southern Powder River Basin, Wyoming: Wyoming Geological Association, 36th Annual Field Conference Guidebook. p. 91-111.

Riggs, N.R., Lehmen, T.M., Gehrels, G.E., and Dickinson, W.R., 1996, Detrital zircon link between headwaters and terminus of the Upper Triassic Chinle-Dockum paleoriver system: Science, v. 273, p. 97-100.

Rocky Mountain Association of Geologists, 1976, Subsurface cross sections of Colorado, Dennis Irwin, Chairman Research Committee, Special Publication 2.

Sharman, G.R., and Johnstone, S.A., 2017, Sediment unmixing using detrital geochronology: Earth and Planetary Science Letters, v. 477, p. 183-194.

Sharman, G.R., Covault, J.A., Stockli, D.F., Wroblewski, A.F-J., and Bush, M.A., 2017, Early Cenozoic drainage reorganization of the United States Western Interior-Gulf of Mexico sediment routing system: Geology, v. 45, no. 2, p. 187-190.

Stephens, M. A., 1970, Use of the Kolmogorov-Smirnov, Cramer-Von Mises and related statistics without extensive tables, J. R. Stat. Soc., Ser. B, 32(1), p. 115-122.

Sundell, K.E., and Saylor, J.E., 2017, Unmixing detrital geochronology age distributions: Geochem. Geophys. Geosyst., 18, 2872-2886.

Saylor, J.E., Stockli, D.F., Horton, B.K., Nie, J., and Mora, A., 2012, Discriminating rapid exhumation from syndepositional volcanism using detrital zircon double dating: Implications for the tectonic history of the eastern cordillera: Geol. Soc. Am. Bull., v. 124, p. $762-779$.

Saylor, J.E., Knowles, J.N., Horton, B.K., Nie, J., and Mora, A., 2013, Mixing of source populations recorded in detrital zircon $\mathrm{U}-\mathrm{Pb}$ age spectra of modern river sands: The Journal of Geology, v. 121, p. 17-33.

Saylor, J.E., and Sundell, K.E., 2016, Quantifying comparison of large detrital geochronology data sets: Geosphere, v. 12, 1, p. 1-18.

Saylor, J.E., Sundell, K.E., and Sharman, G.R., 2019, Characterizing sediment sources by nonnegative matrix factorization of detrital geochronological data: Earth and Planetary Science Letters, v. 512, p. 46-58. 
Swineford, A. and Williams, H.L., 1945, The Cheyenne Sandstone and adjacent formations of a part of Russell County, Kansas: Kansas Geological Survey, Bulletin 60.

Thomas, W.A., Gehrels, G.E., Greb, S.F., Nadon, G.C., Satkoski, A.M., and Romero, M.C., 2017, Detrital zircons and sediment dispersal in the Appalachian foreland: Geosphere, v. 13, no. 6 , p. 2206-2230.

Trujillo, K., and Kowallis, B., 2015, Recalibrated legacy 40Ar/39Ar ages for the Upper Jurassic Morrison Formation, Western Interior, USA: Geology of the Intermountain West, v. 2, p. $1-8$.

Vermeesch, P., 2012, On the visualization of detrital age distributions: Chemical Geology, v. 312-313, p. 190-194.

Vermeesch, P., 2013, Multi-sample comparison of detrital age distributions: Chemical Geology, v. 341, p. 140-146.

Vermeesch, P., Resentini, A., and Garzanti, E., 2016, an R package for statistical provenance analysis: Sedimentary Geology, v. 336, p. 14-25.

Waagé, K.M., 1953, Refractory clay deposits of south-central Colorado: U.S. Geological Survey Bulletin 933, 104p.

Waagé, K.M., 1955, Dakota Group in northern Front Range Foothills, Colorado: U.S. Geological Survey Prof. Paper 274-B, p. 15-51.

Waagé, K.M., 1958, Regional aspects of Inyan Kara stratigraphy, in Powder River Basin of Wyoming; 13th Annual Field Conference Guidebook: Wyoming Geological Association, p. $71-76$.

Waagé, K.M., 1959, Regional aspects of Inyan Kara stratigraphy in the Black Hills, South Dakota and Wyoming: Washington, D.C., United States Geological Survey Bulletin 1081B, p. 11-90.

Way, J.N., O’Malley, P.J., Suttner, L.J., and Furer, L.C., 1998, Tectonic controls on alluvial systems in a distal foreland basin: the Lakota and Cloverly Formations (Early Cretaceous) in Wyoming, Montana, and South Dakota, in Relative Role of Eustasy, Climate, and Tectonism in Continental Rocks, SEPM Special Publication No. 59, p. 133-147.

Weimer, R.J., 1970, Dakota group (Cretaceous) stratigraphy, Southern Front Range, South and Middle Parks, Colorado: The Mountain Geologist, v. 7, p. 157-184.

Weimer, R.J., and Sonnenberg, S.A., 1982, Wattenberg field, paleostructure-stratigraphic trap, Denver basin, Colorado: Oil \& Gas Journal, v. 80, no. 12, p. 204-210.

Weimer, 1984, Relation of unconformities, tectonics, and sea-level changes, Cretaceous of 
Western Interior, U.S.A., in Schlee, J.S., ed., Interregional Unconformities and Hydrocarbon Accumulation: American Association of Petroleum Geologists, Memoir 36, p. $7-35$.

Weimer, R.J., Rebne, C.A., and Davis, T.L., 1988, Geologic and seismic models, Muddy Sandstone, Lower Cretaceous, Bell Creek-Rocky Point Area, Powder River Basin, Montana and Wyoming: Eastern Powder River Basin - Black Hills; 39th Annual Field Conference Guidebook, p. 161-177.

Weimer, R.J., Dolson, J.C., Ethridge, F.G., and Warme, J., 1990, 2-Day Geology Field Trip, Sequence Stratigraphy -Lower K, Fort Collins, Boulder, Morrison Area: Rocky Mountain Association of Geologists, $130 \mathrm{p}$.

Wescott, W.A., 1979, Field Trip No. 1, Part C, Lower Dakota Group depositional environments and stratigraphic evolution: Colorado Front Range, Larimer County, Colorado, in Ethridge, F.G., (ed.), Field Guide Northern Front Range and Northwest Denver Basin, Colorado: Guidebook for post-meeting field trips held in conjuctions with the 32nd Annual Meeting of the Rocky Mountain Section, Geological Society of America, p. 55-85.

Whitmeyer, S.J., and Karlstrom, K.E., 2007, Tectonic model for the Proterozoic growth of North America: Geosphere, v. 3, no. 4, p. 220-259.

Willis, B.J., 1997, Architecture of fluvial-dominated valley-fill deposits in the Cretaceous Fall River Formation: Sedimentology, v. 44, p. 735-757.

Witzke, B.J., and Ludvigson, G.A., 1994, The Dakota Formation in Iowa and the type area, in Shurr, G.W., Ludvigson, G.A., and Hammond, R.H., eds., Perspectives on the Eastern Margin of the Cretaceous Western Interior Basin: Boulder, Colorado, Geological Society of America Special Paper 287.

Zaleha, M.J., 2013, Paleochannel hydraulics, geometries, and associated alluvial architecture of Early Cretaceous rivers, Sevier Foreland Basin, Wyoming, USA: Elsevier Cretaceous Research, v. 45, p. 321-341. 


\section{Figures}

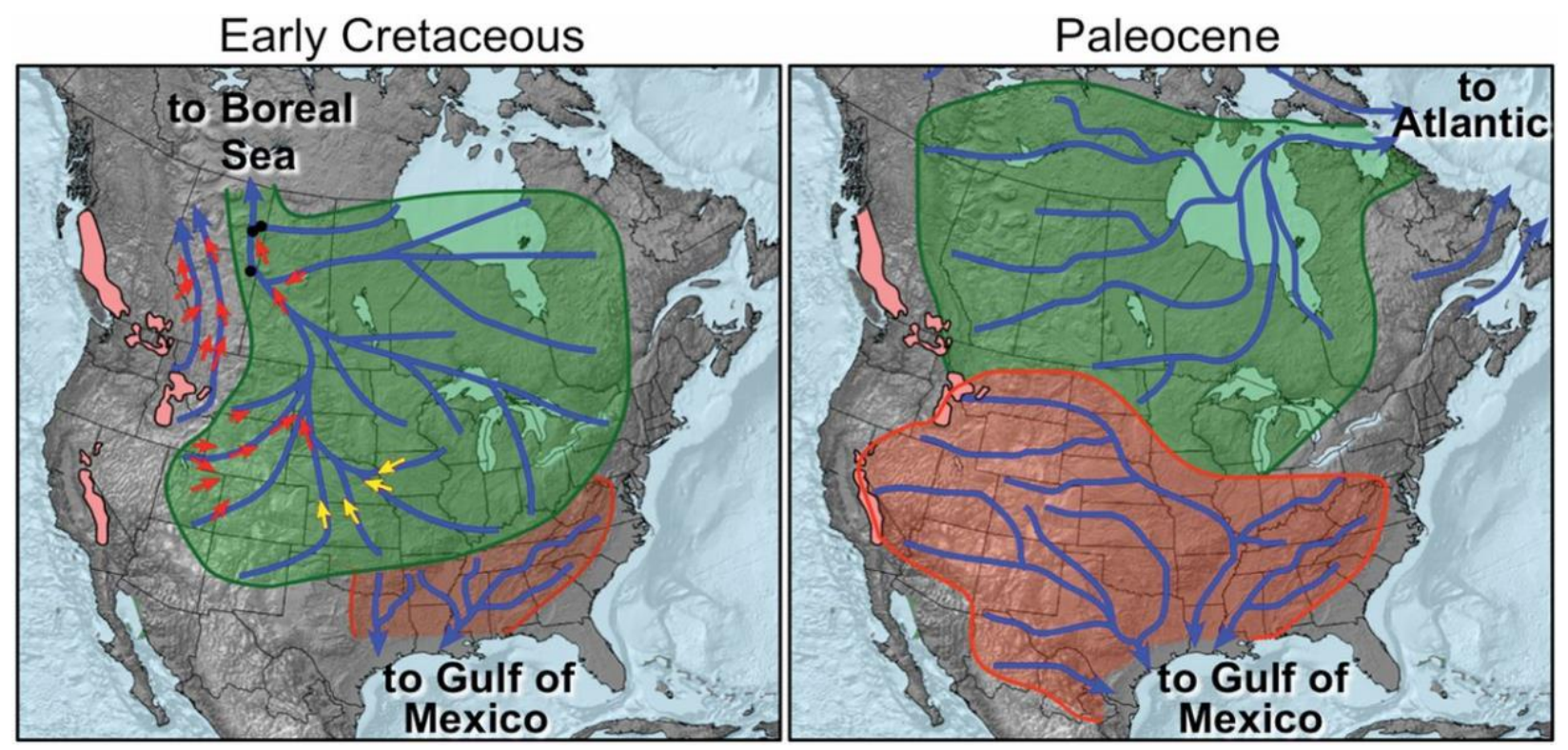

Figure 1: Hypothesis for the continental-scale shift in sediment routing and change in drainage patterns from the Early Cretaceous to the Paleocene-Early Eocene in North America. Red arrows are paleocurrents from Lower Cretaceous deposits (from Blum and Pecha, 2014). 


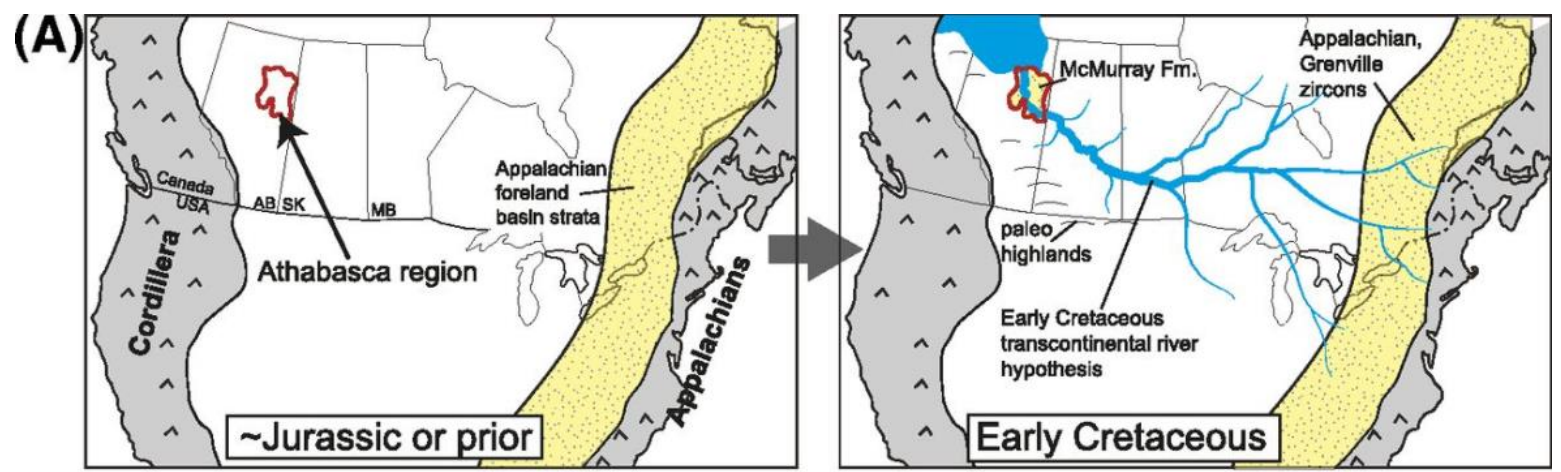

(B)
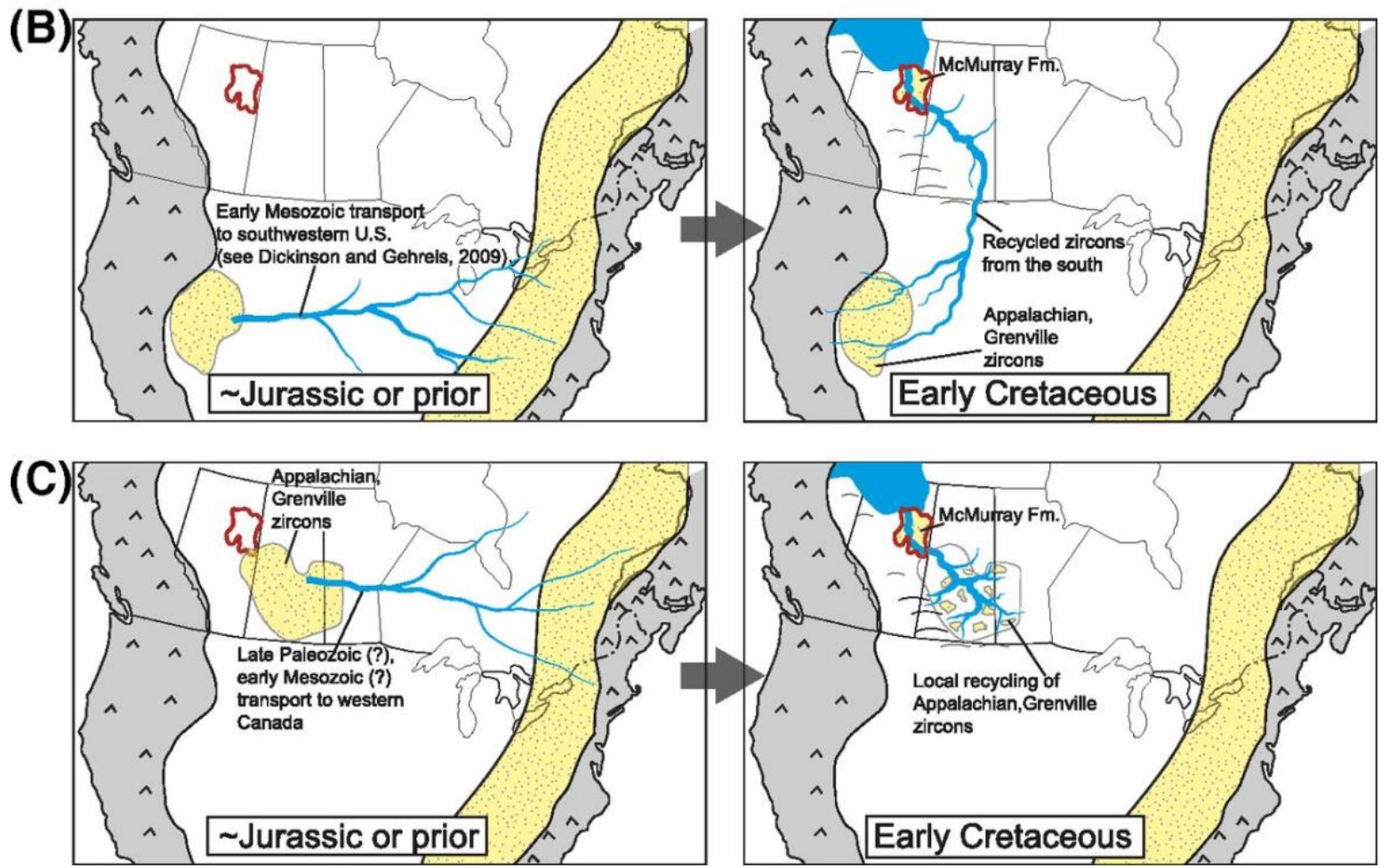

Figure 2: Three alternative hypotheses for the large-scale shift in sediment routing and drainage patterns. (A) Sediments derived from the Appalachians and transported to northeastern Alberta during the Early Cretaceous. (B) Sediments transported to the southwestern United States and then transported north to Alberta during the Early Cretaceous. (C) Sediments transported from the Appalachians to western Canada, followed by recycling from the Canadian shield during the Early Cretaceous (from Benyon et al., 2016). 


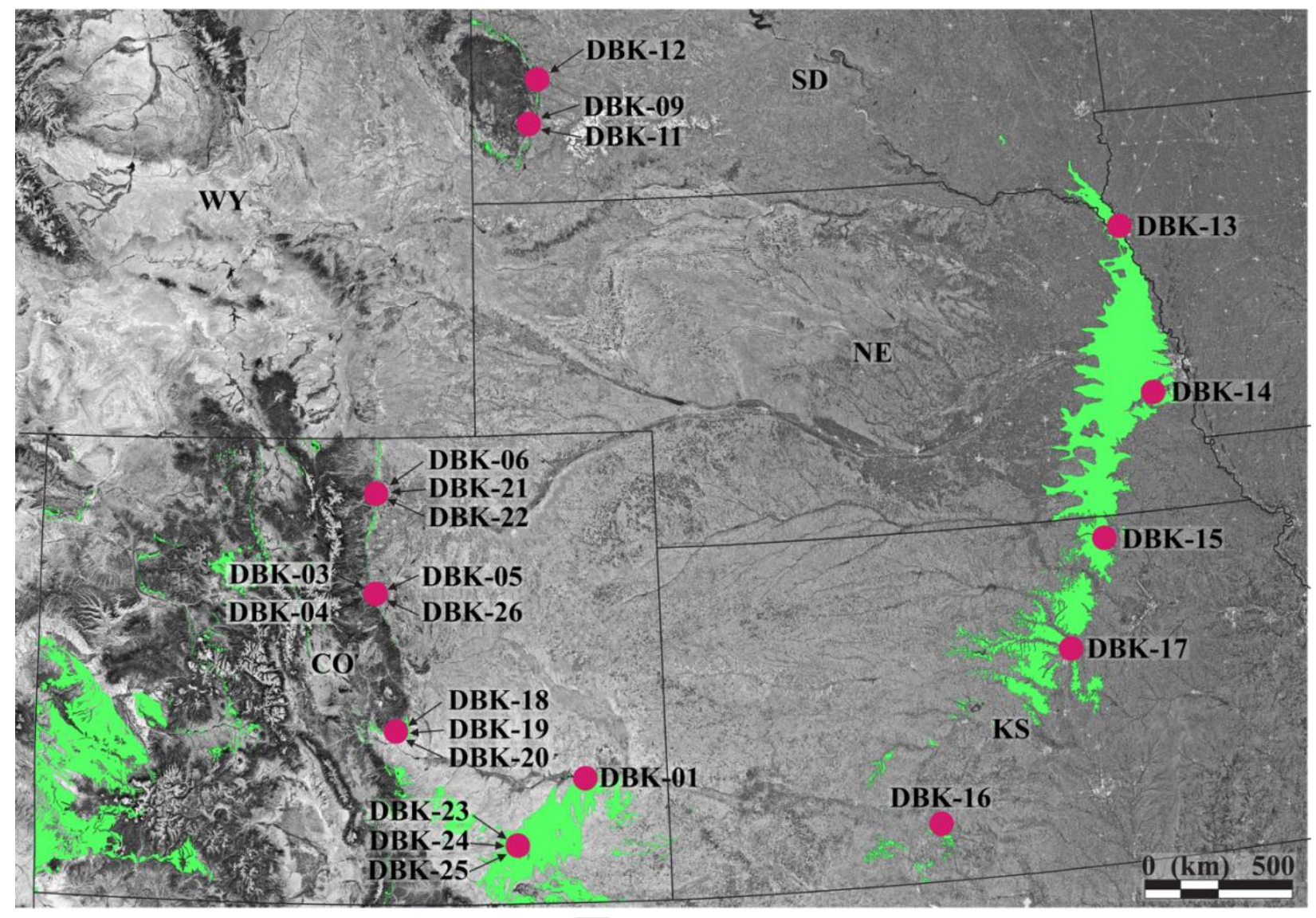

Geographic extent of the Morrison, Lytle, and Dakota formations

Figure 3: Map showing locations where samples were collected. Coordinates of individual sample locations are included in Table 3. 


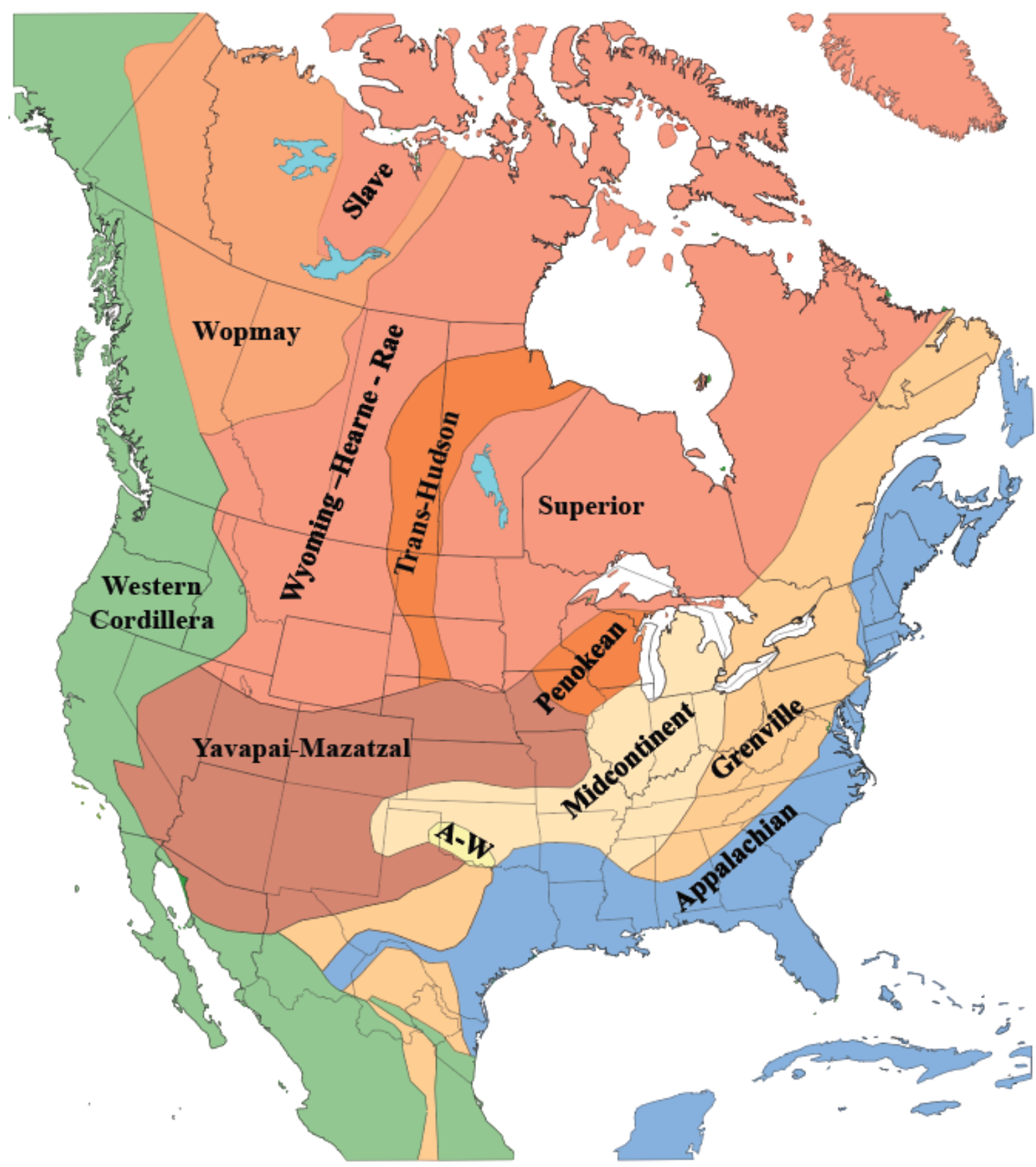

Figure 4: Primary source terrains for detrital zircons in North America (from Blum and Pecha, 2014, originally from Dickinson and Gehrels, 2009). For further explanation, see Table 2. 


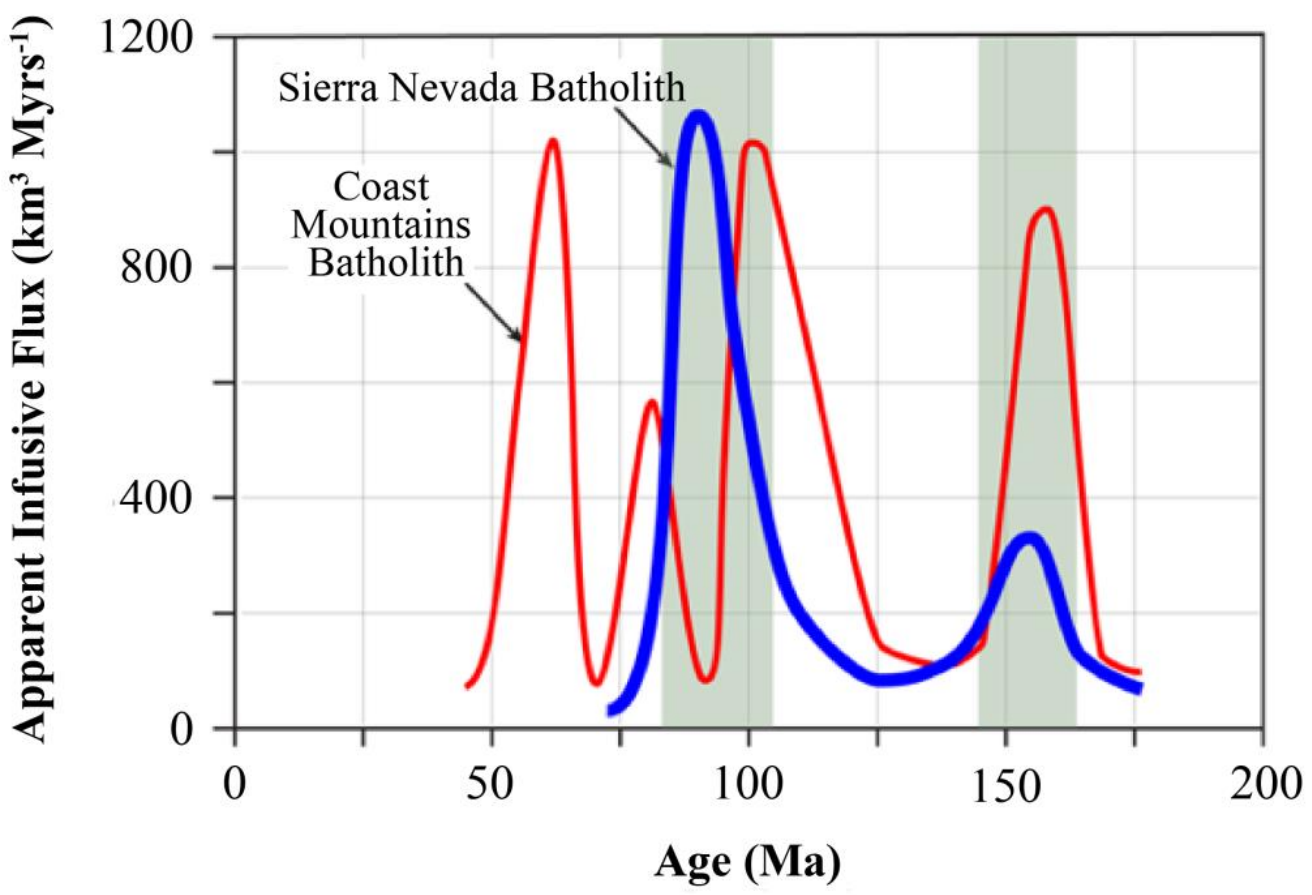

Figure 5: Apparent infusive flux rates for the Sierra Nevada batholith and the Coast Mountains batholith over the past $200 \mathrm{Ma}$ (adapted from DeCelles et al., 2009). 


\section{Idealized Section}

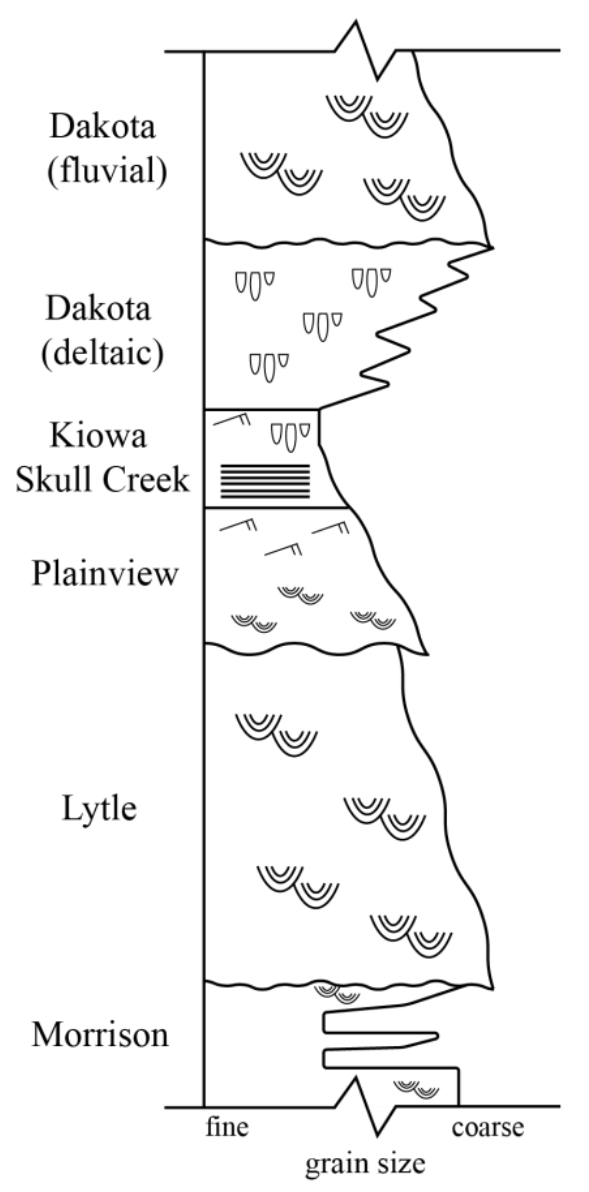

\section{Interpreted}

Depositional

\section{Environment}

\section{Shoreline Trajectory}

fluvial

deltaic shoreline

shelf

mixed fluvial and nearshore

marine

mixed bedrock-alluvial valley

system

meandering fluvial system on a floodplain

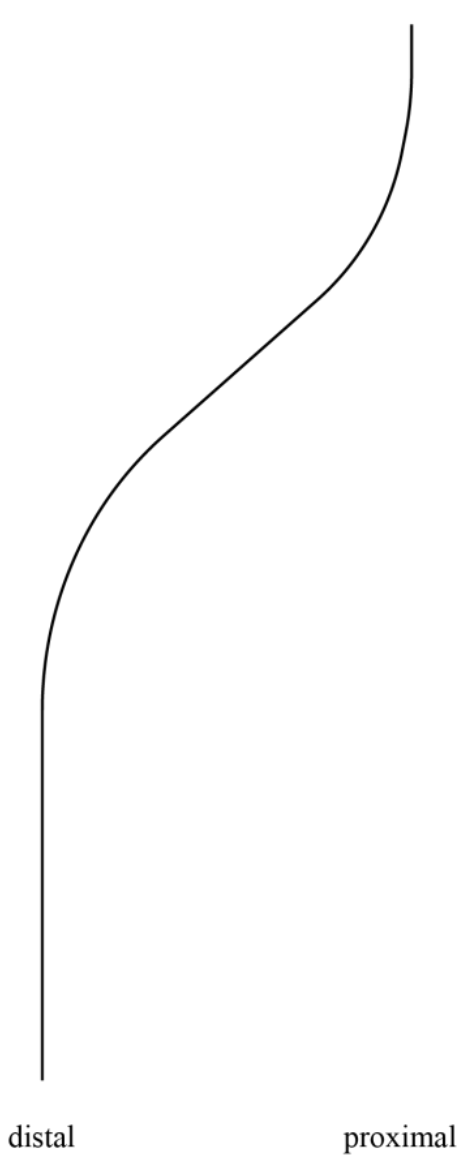

Figure 6: Idealized composite stratigraphic section for the Late Jurassic through Cenomanian deposits of the Colorado Front Range, illustrating interpreted depositional environments and an approximate shoreline trajectory. 


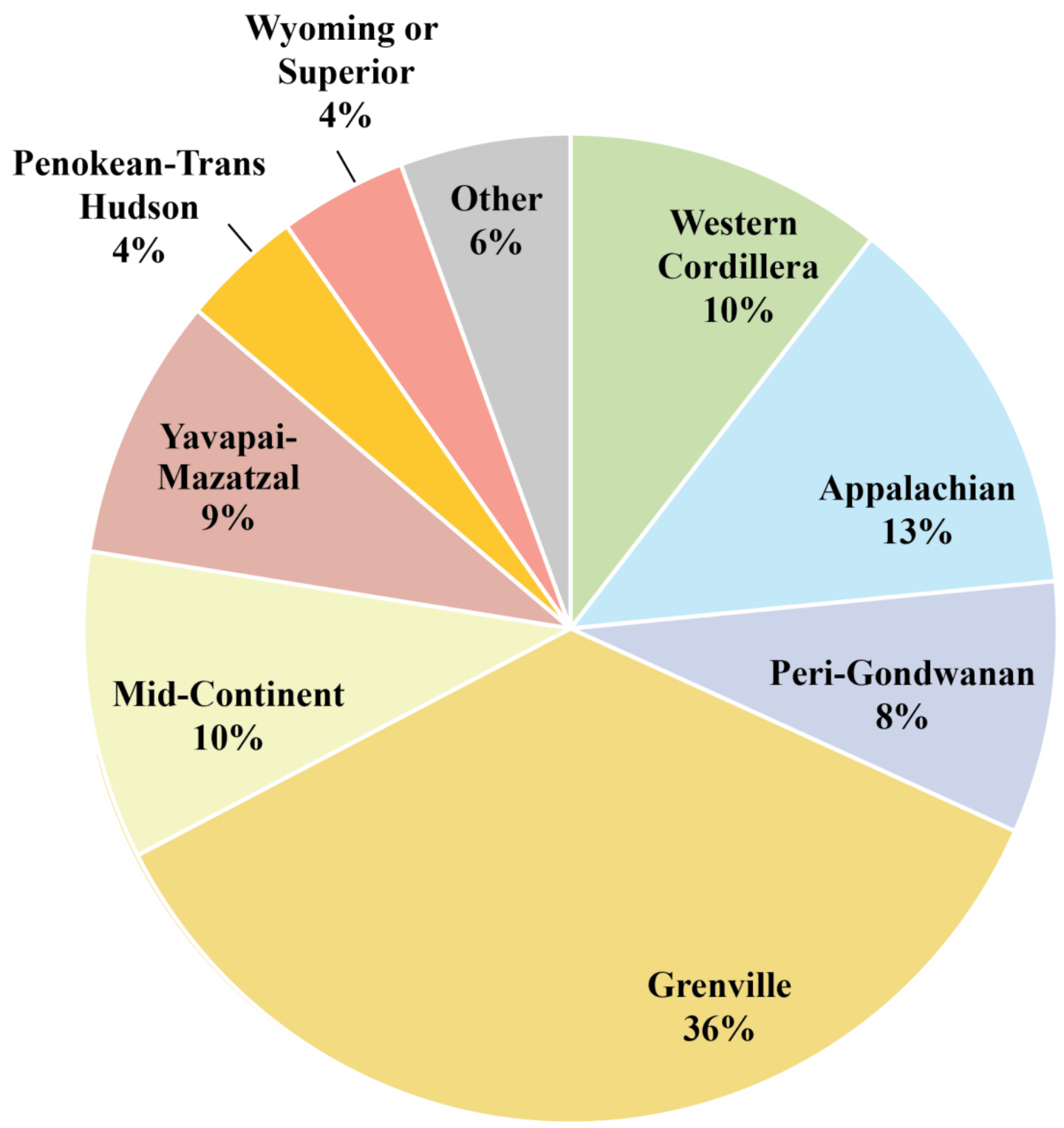

Figure 7: Total average percentage of age populations present within each sample. 


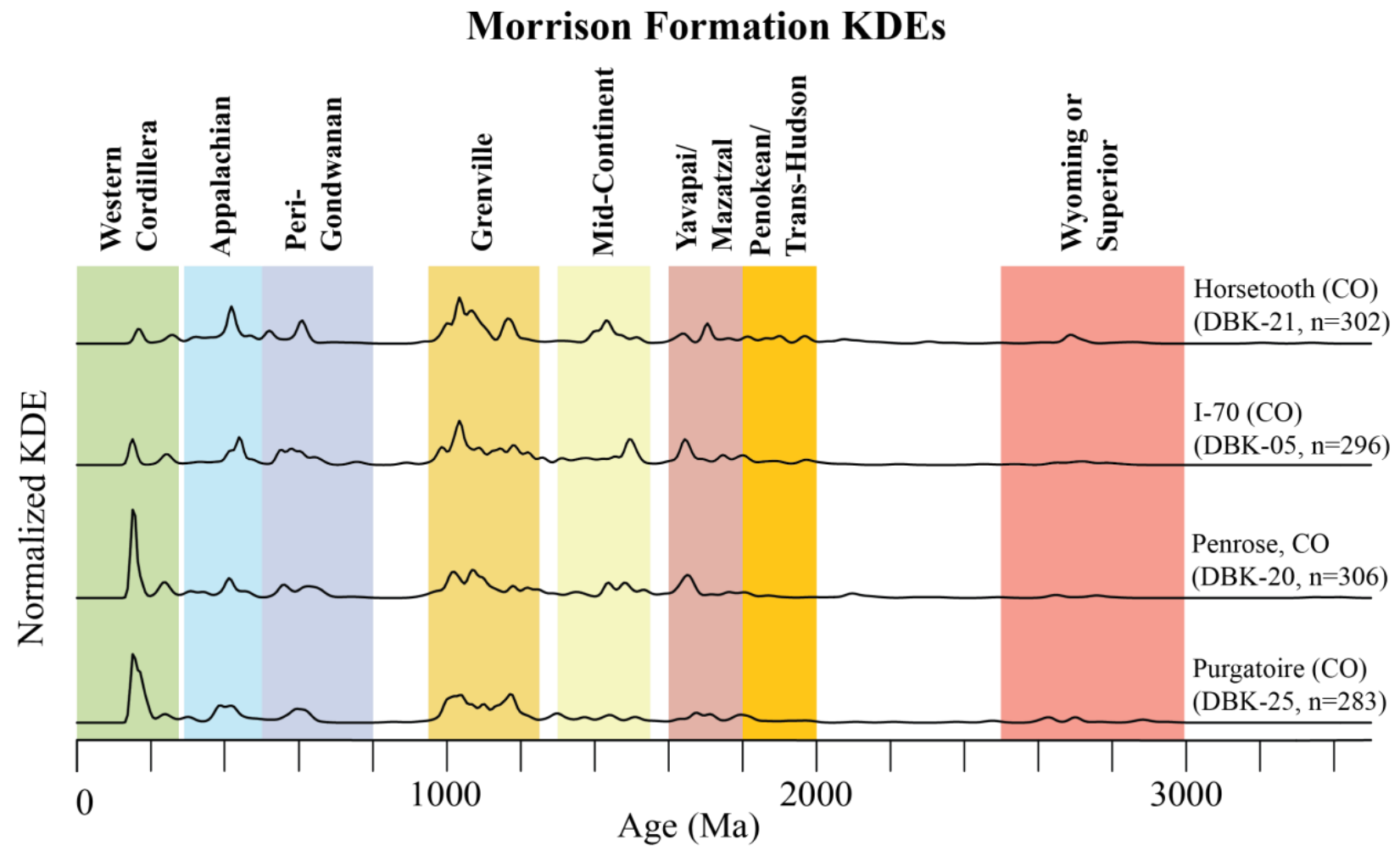

Figure 8: Normalized KDEs (bandwidth=10 Myr) for samples collected from the Late Jurassic Morrison Formation, ordered top to bottom from north to south along the Front Range. 


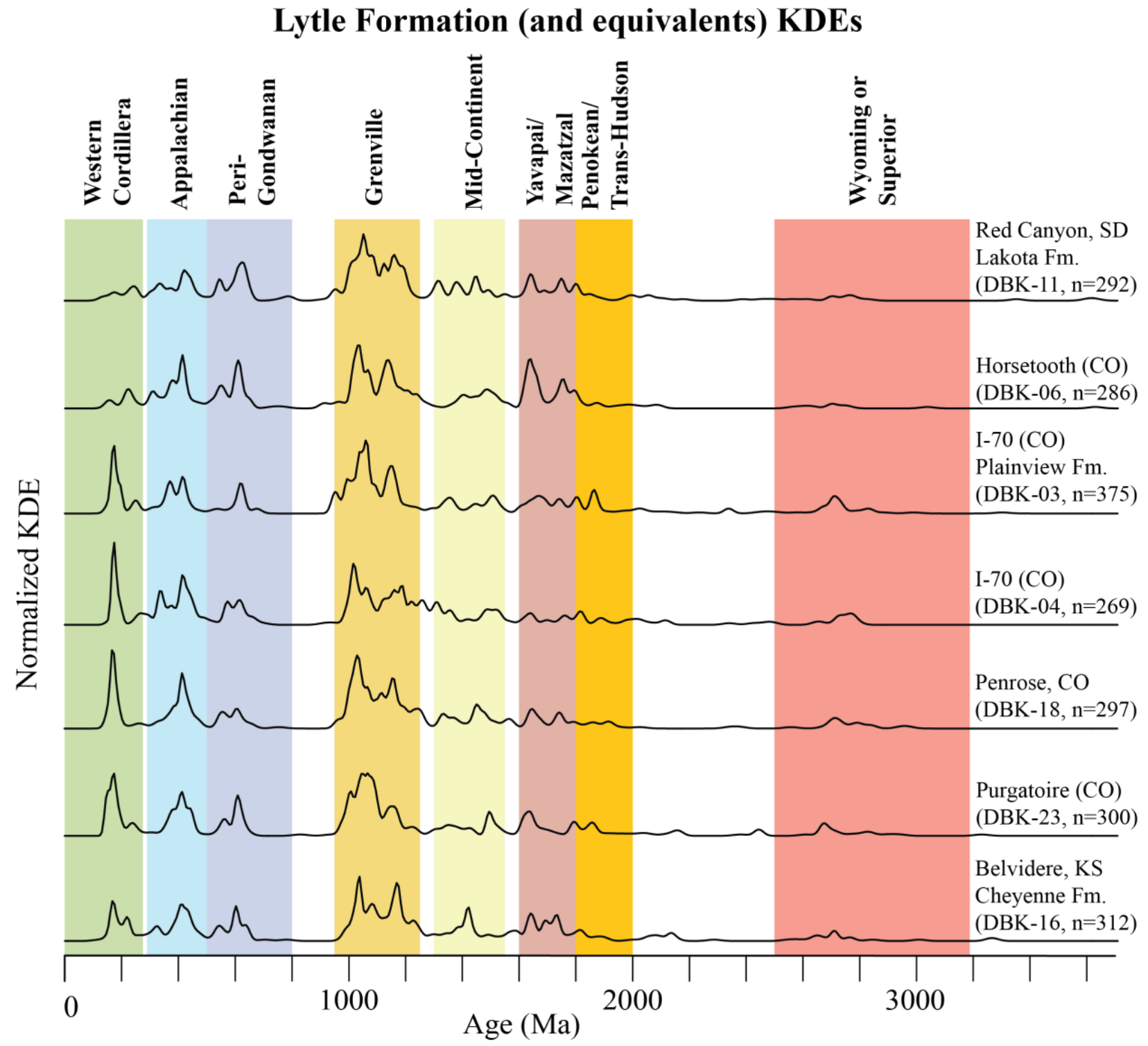

Figure 9: Normalized KDEs (bandwidth=10 Myr) for samples collected from the Early Cretaceous Lytle Formation and its equivalents, ordered top to bottom from north to south. 


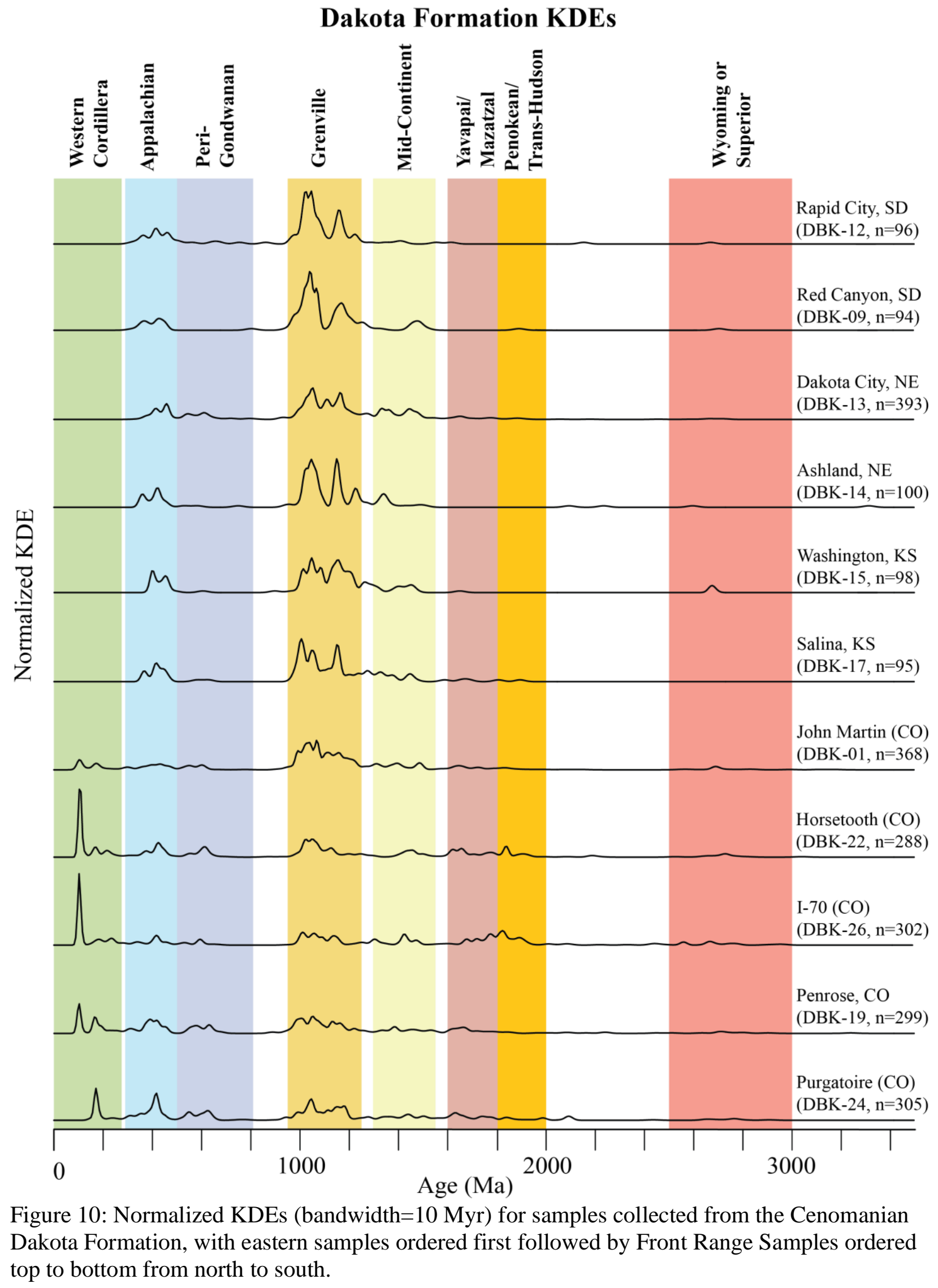




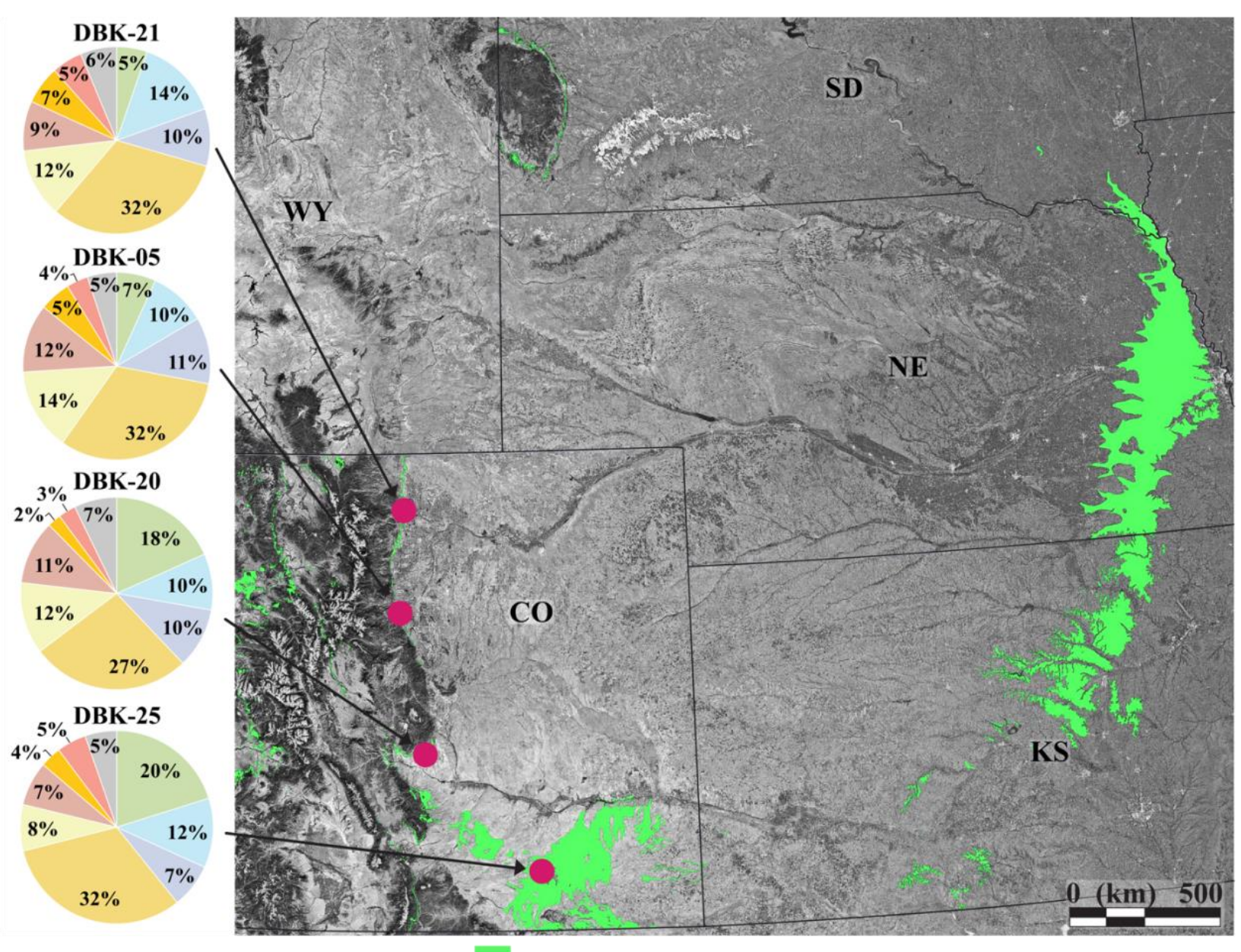

Geographic extent of the Morrison, Lytle, and Dakota formations

Figure 11: Charts of the average percentage of age populations present for each Morrison Formation sample, paired with the sample location. Pie colors match those of the source terrane map in Figure 2 and the ages in Table 2. 


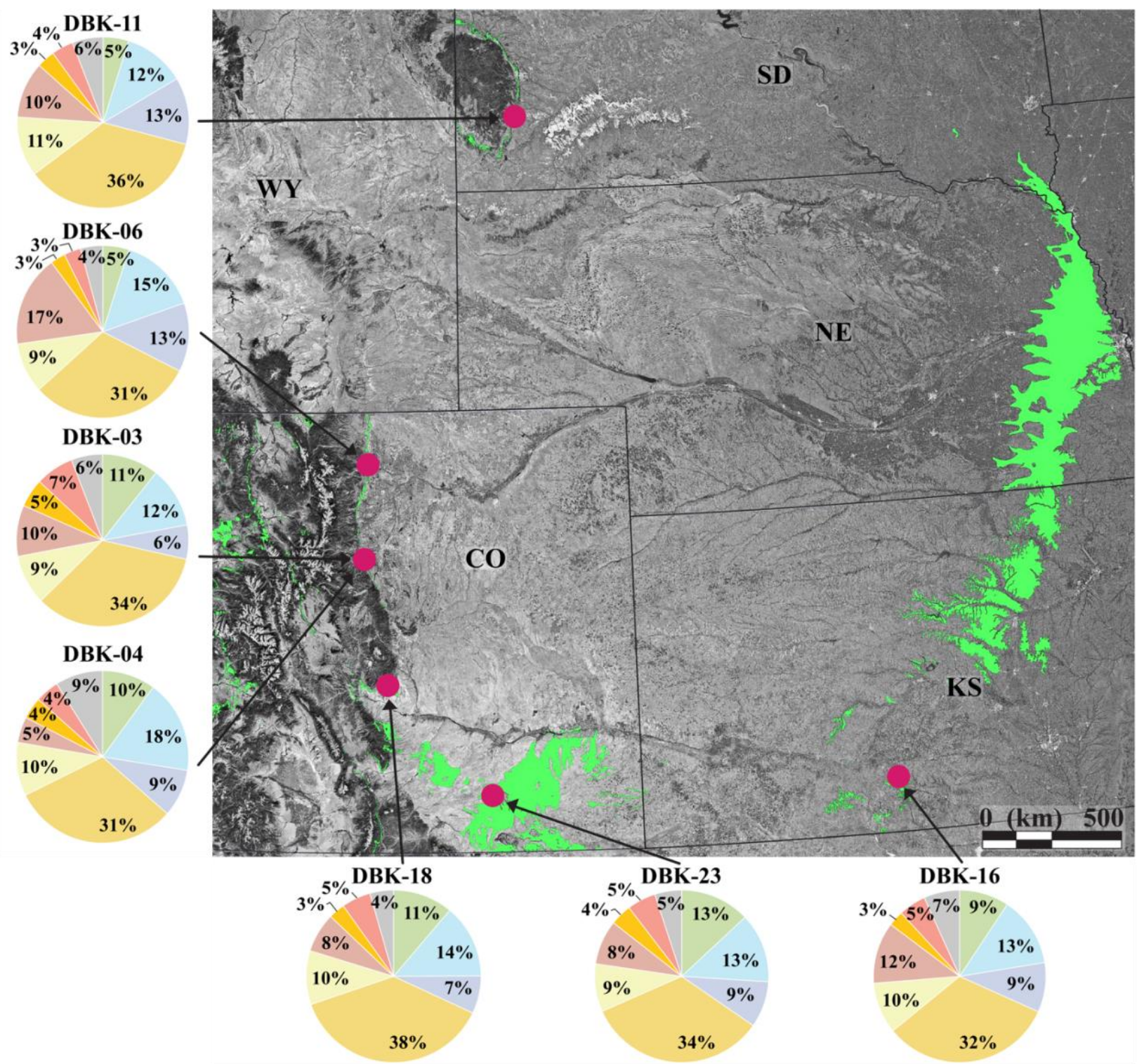

Geographic extent of the Morrison, Lytle, and Dakota formations

Figure 12: Charts of the average percentage of age populations present for each Lytle Formation (and equivalents) sample, paired with the sample location. Pie colors match those of the source terrane map in Figure 2 and the ages in Table 2. 


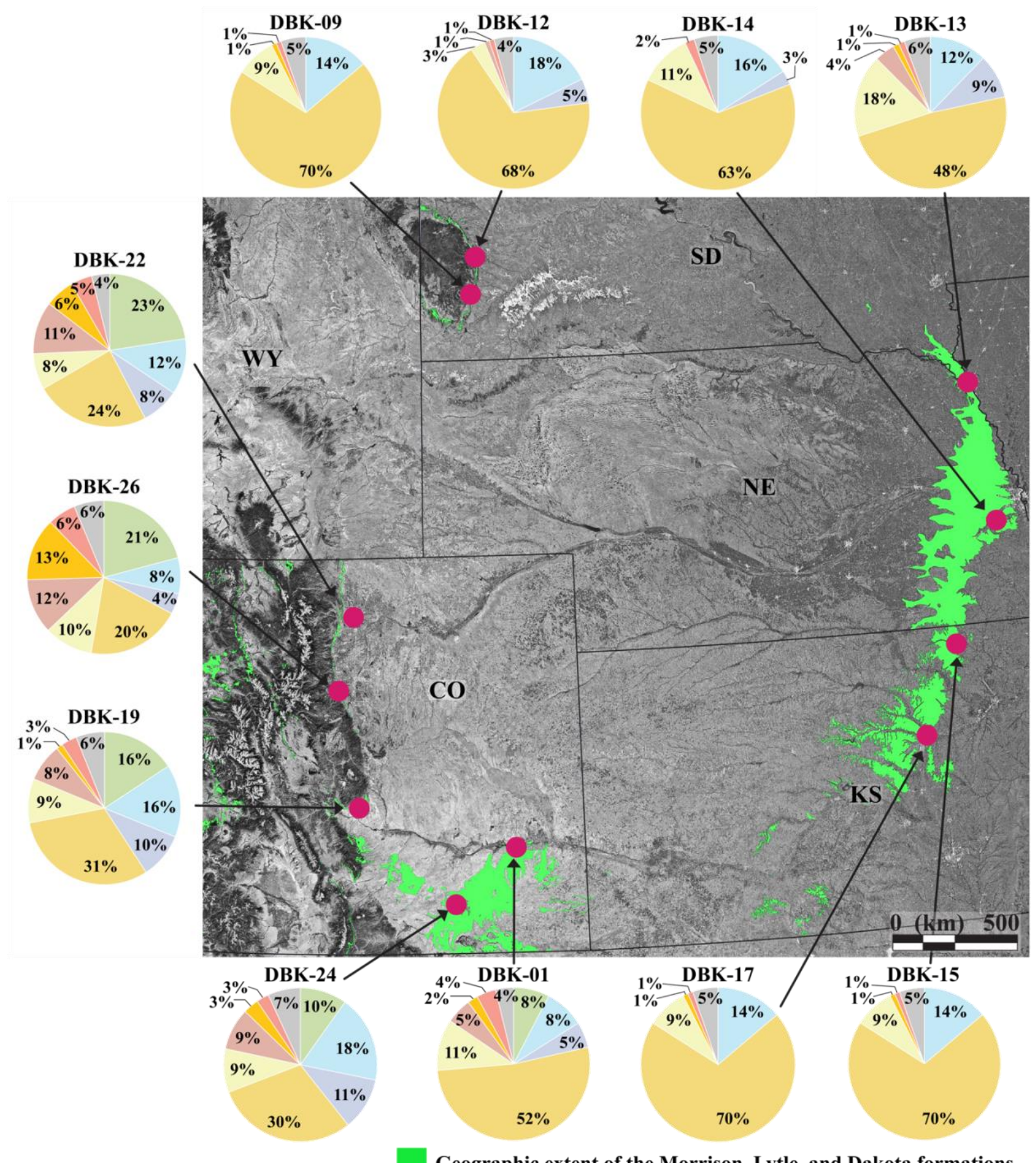

Geographic extent of the Morrison, Lytle, and Dakota formations

Figure 13: Charts of the average percentage of age populations present for each Dakota Group sample, paired with the sample location. Pie colors match those of the source terrane map in Figure 2 and the ages in Table 2. 


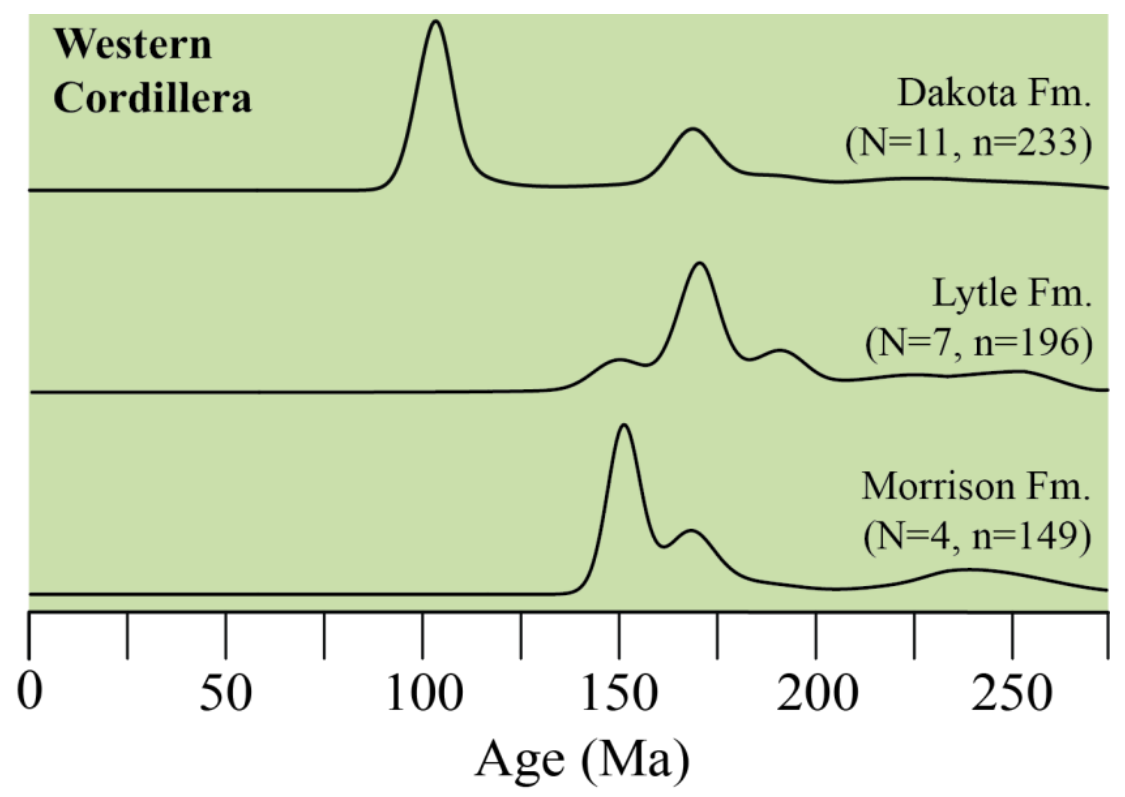

Figure 14: Normalized KDEs (bandwidth=10 Myr) for samples collected from the Morrison, Lytle (and its equivalents), and Dakota formations, only including grains <275 Ma sourced from the Western Cordilleran magmatic arc. 


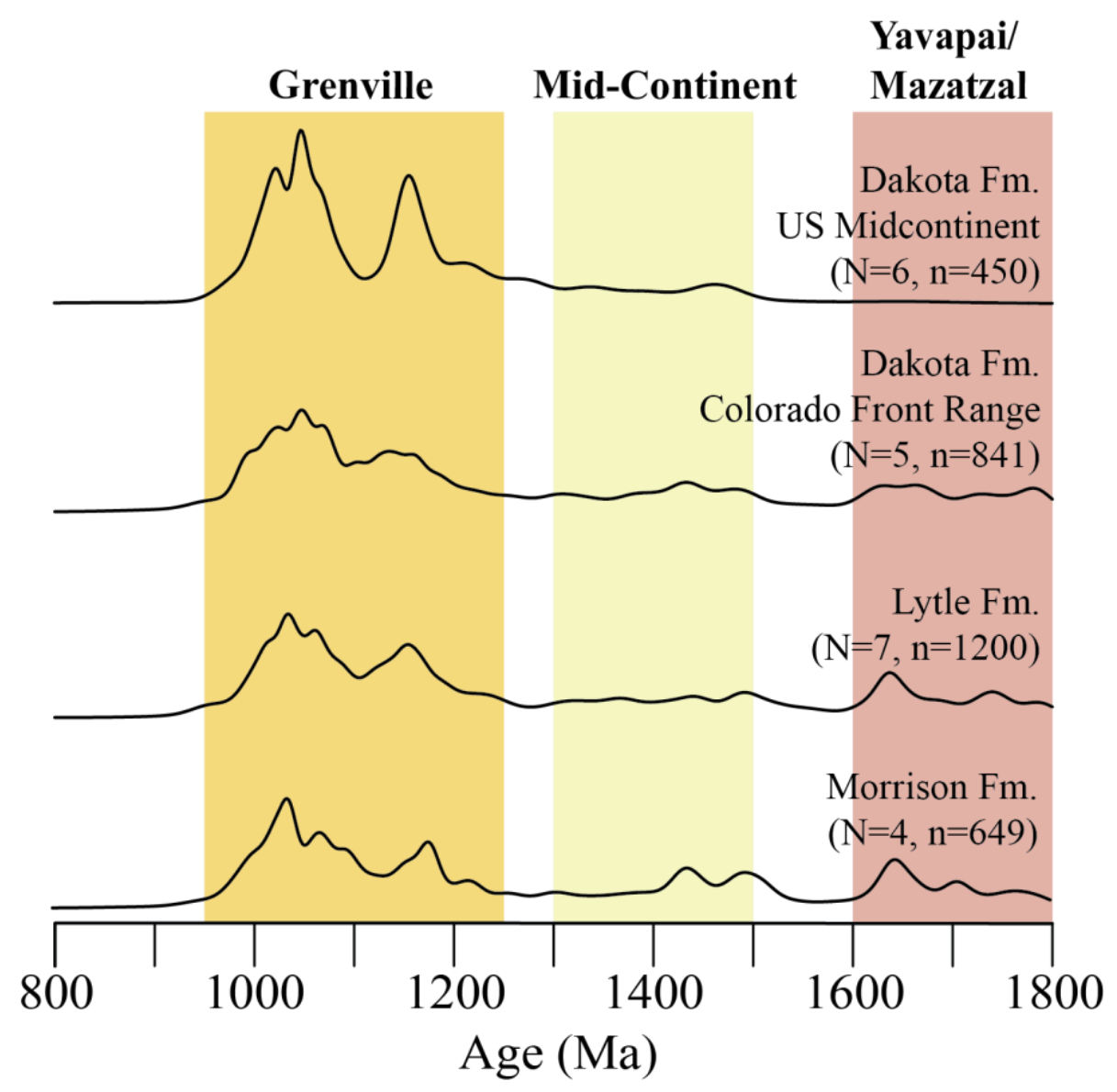

Figure 15: Normalized KDEs (bandwidth=10 Myr) for samples collected from the Morrison, Lytle (and its equivalents), and Dakota (split among western- and eastern-derived samples) formations, only including grains 800-1800 Ma. 

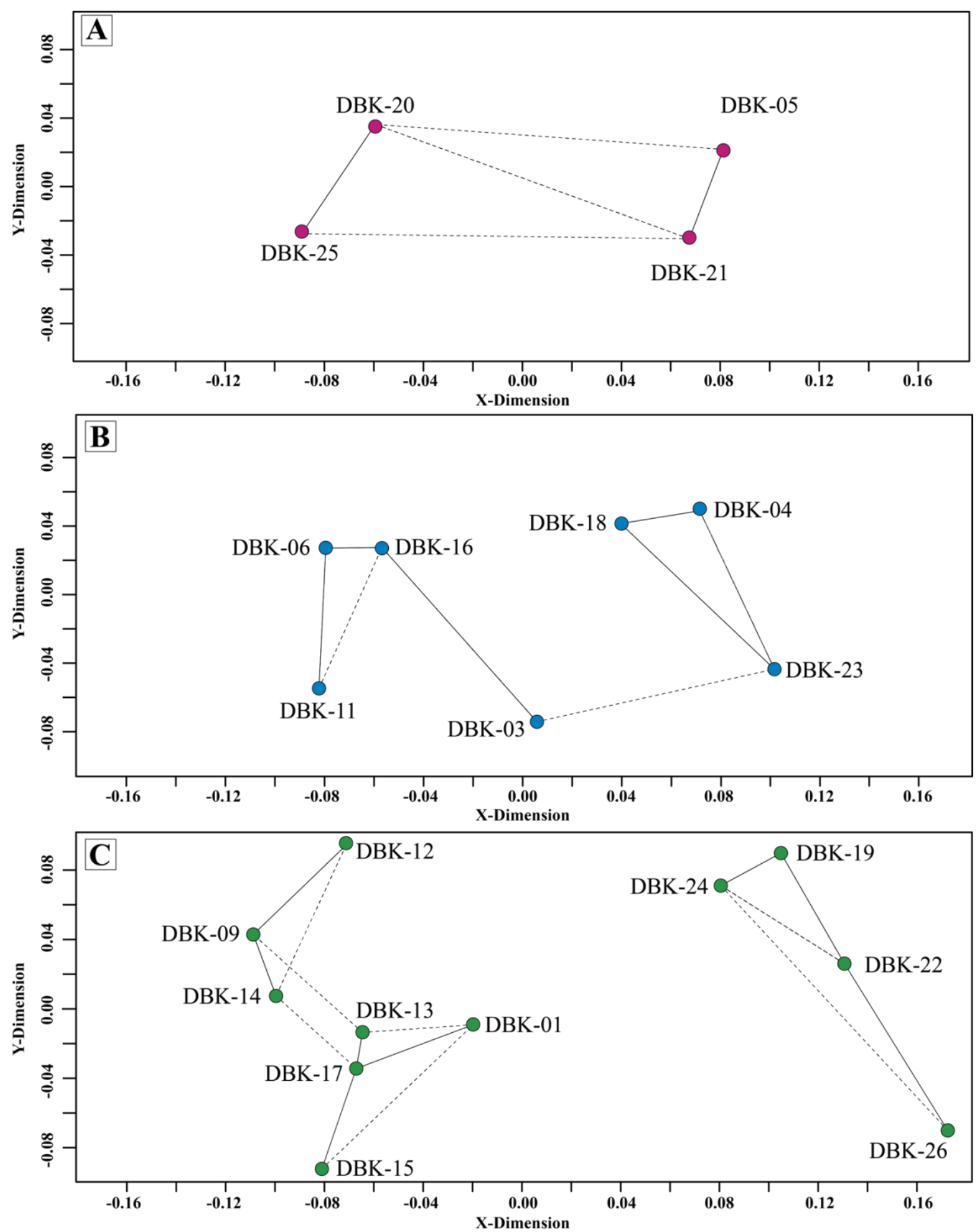

Figure 16: Multidimensional scaling plots projected into two dimensions for (A) Morrison Formation samples, (B) Lytle Formation (and age-equivalent) samples, and (C) Dakota Formation samples. Solid lines connect the closest neighbors and dashed lines connect the second closest neighbors. 


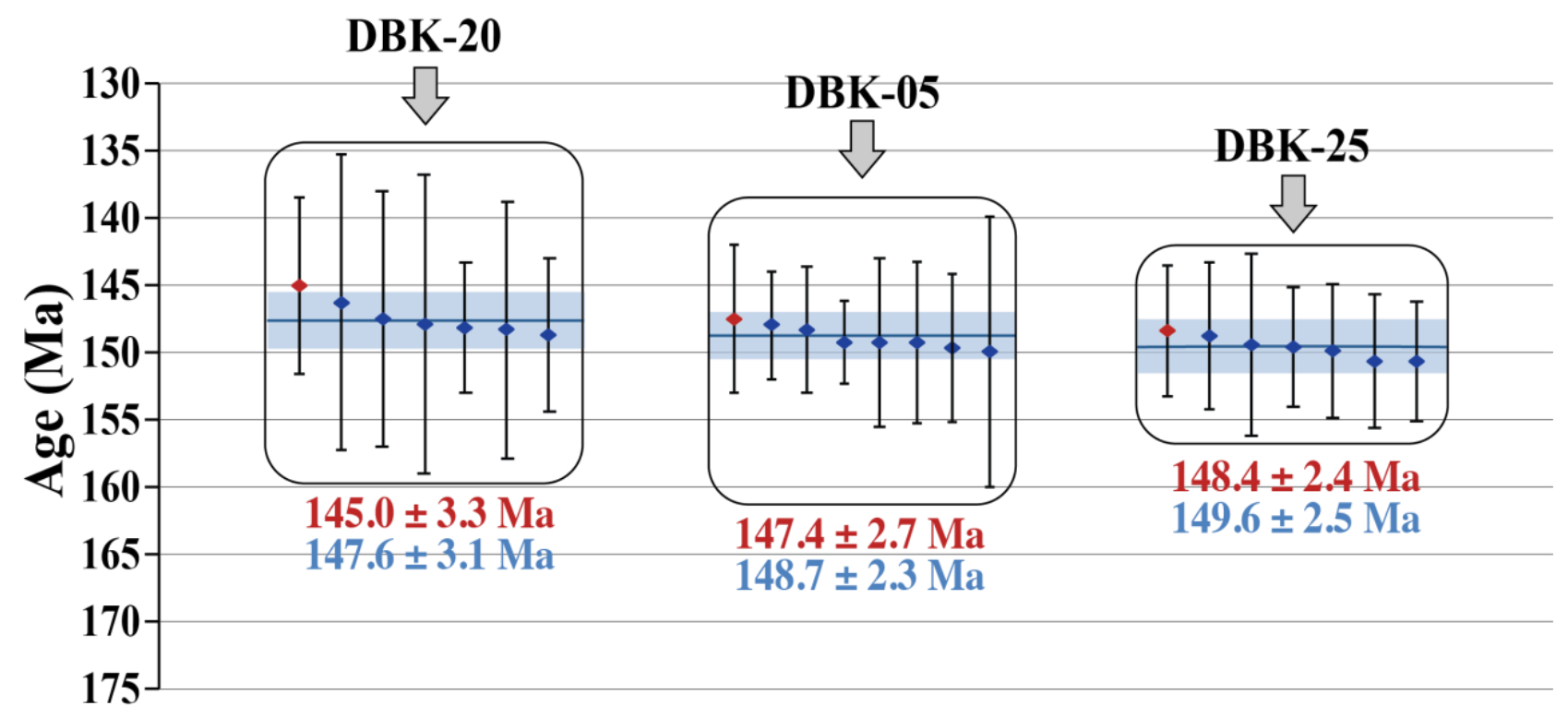

Youngest Grain

Maximum Depositional Age

Figure 17: Calculated MDAs of Morrison Formation samples for which there were enough young volcanogenic grains $(n \geq 2)$ to calculate the MDA. Youngest grains for each sample are shown in red, the calculated weighted MDA as the blue line, and the weighted MDA error $(2 \sigma)$ is represented by the blue box. Error bars represent $2 \sigma$ uncertainty. 


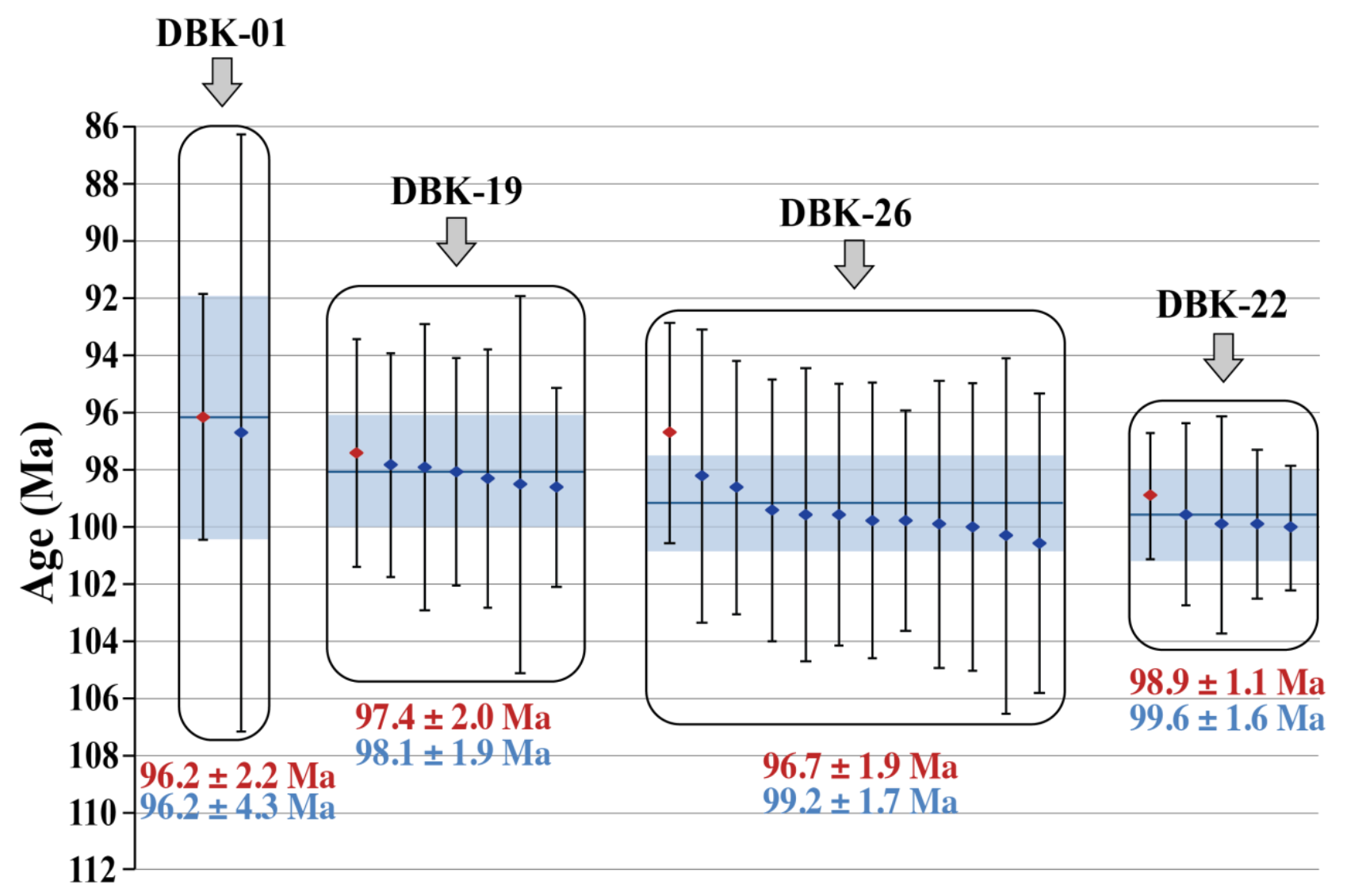

Youngest Grain

Maximum Depositional Age

Figure 18: Calculated MDAs of Dakota Formation samples for which there were enough young volcanogenic grains $(n \geq 2)$ to calculate the MDA. Youngest grains for each sample are shown in red, the calculated weighted MDA as the blue line, and the weighted MDA error $(2 \sigma)$ is represented by the blue box. Error bars represent $2 \sigma$ uncertainty. 


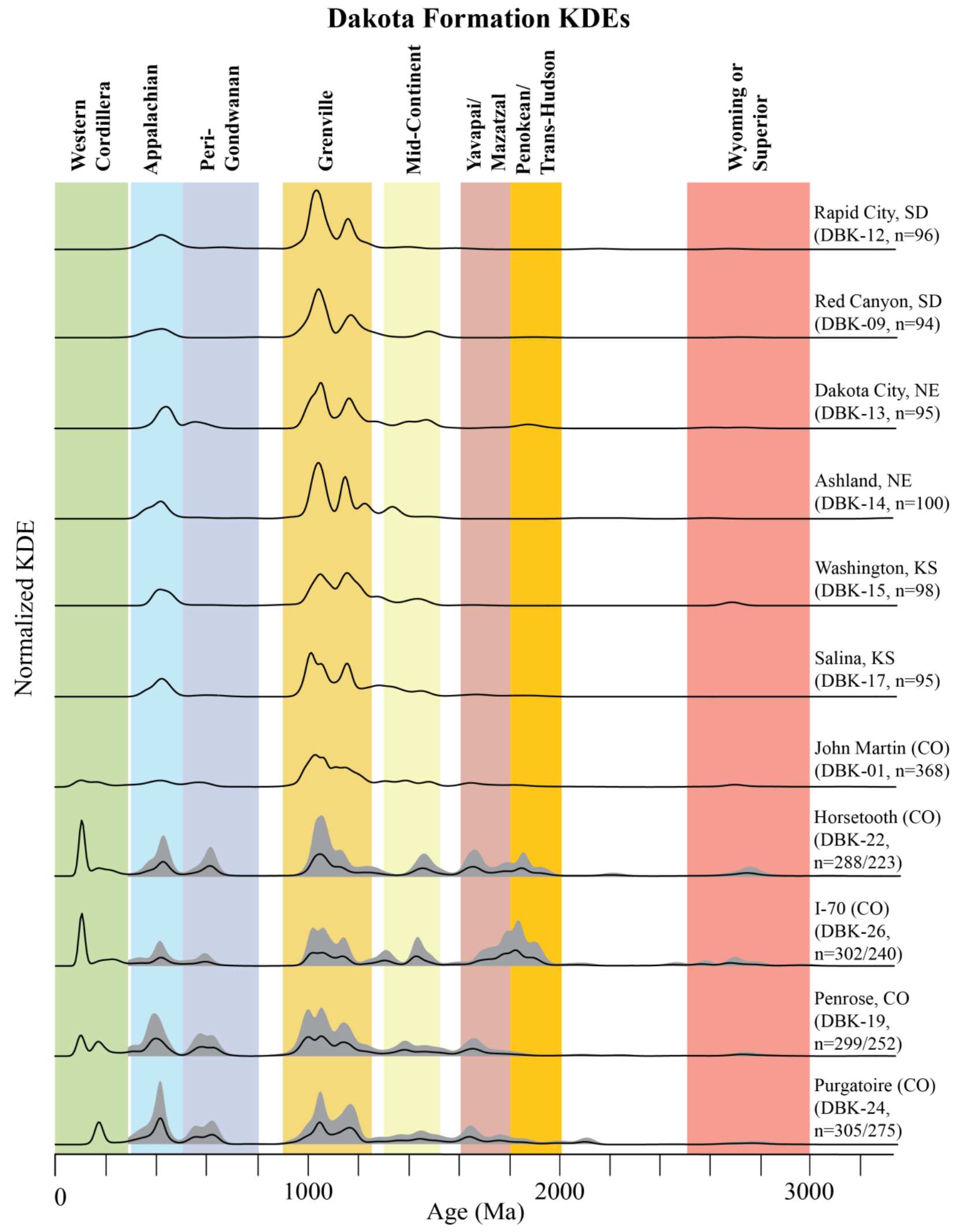

Figure 19: Normalized KDEs (bandwidth=20 Myr) for samples collected from the Dakota Formation, with eastern samples ordered first followed by Front Range Samples ordered top to 
bottom from north to south. A second gray curve with all grains $>275 \mathrm{Ma}$ has been plotted behind the primary curve for all samples with significant Western Cordilleran contributions.
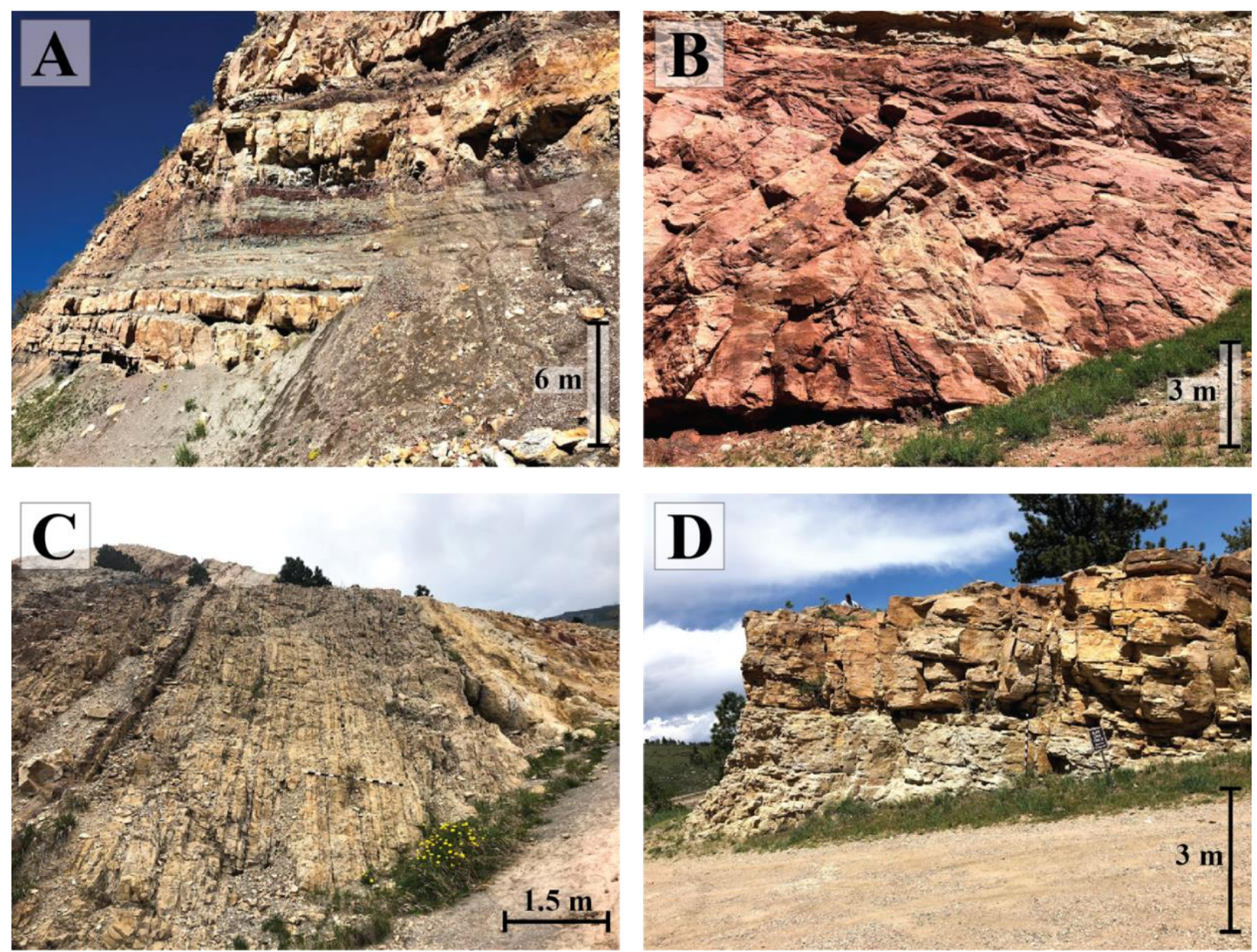

Figure 20: Pictures from the Colorado Front Range illustrating the different types of fluvial styles represented in the A) Morrison Formation; B) Lytle Formation; C) Plainview Formation; and D) Dakota Formation. 


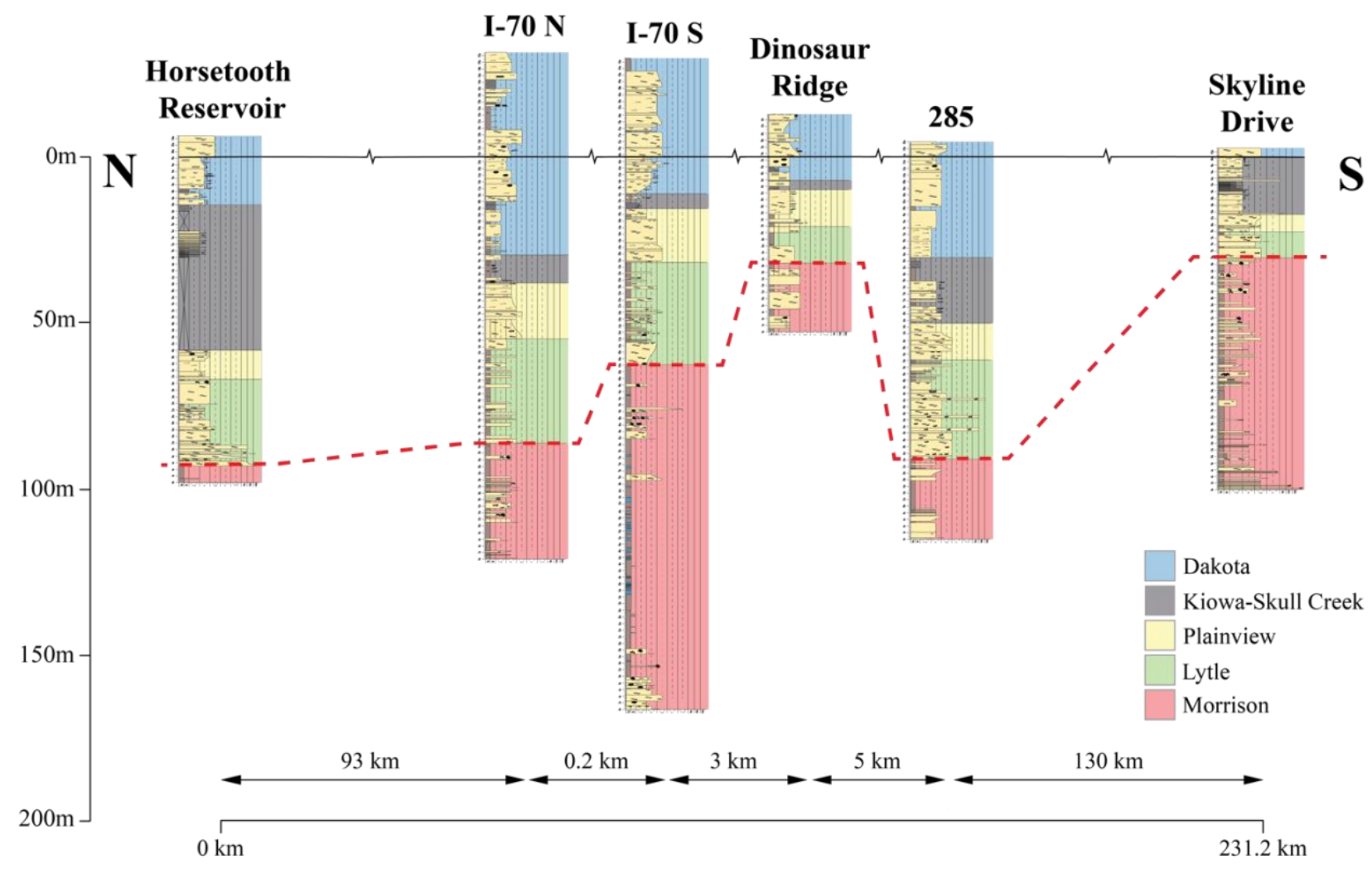

Figure 21: North-to-south transect of the measured sections included in this study, hung on the Dakota fluvial surface (black line). The red dashed line is at the basal Cretaceous unconformity. 


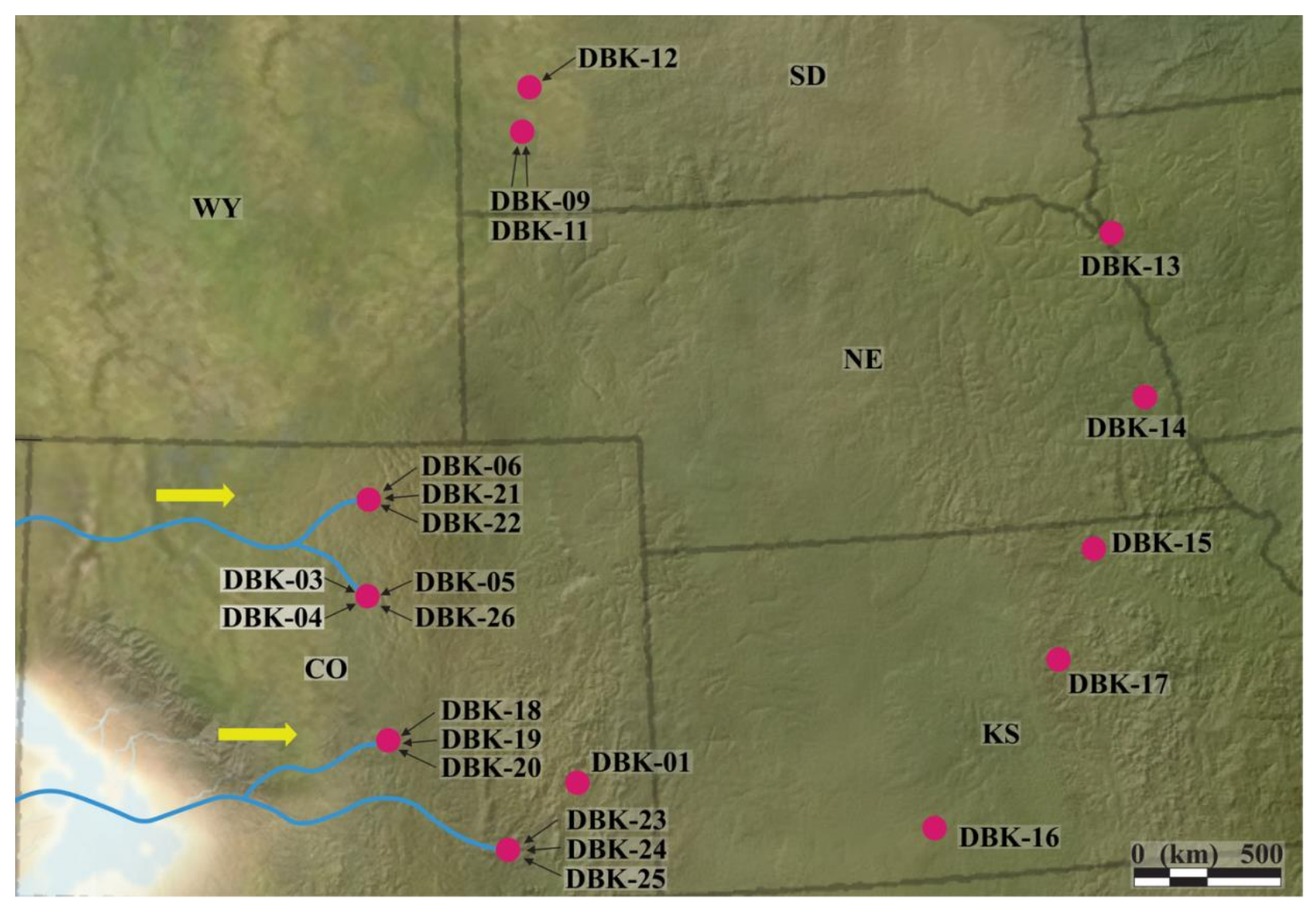

Figure 22: Paleodrainage reconstruction of the study area during deposition of the Morrison Formation, represented on a Blakey map from the Late Jurassic (150-148 Ma). Yellow arrows point in the direction of flow. 


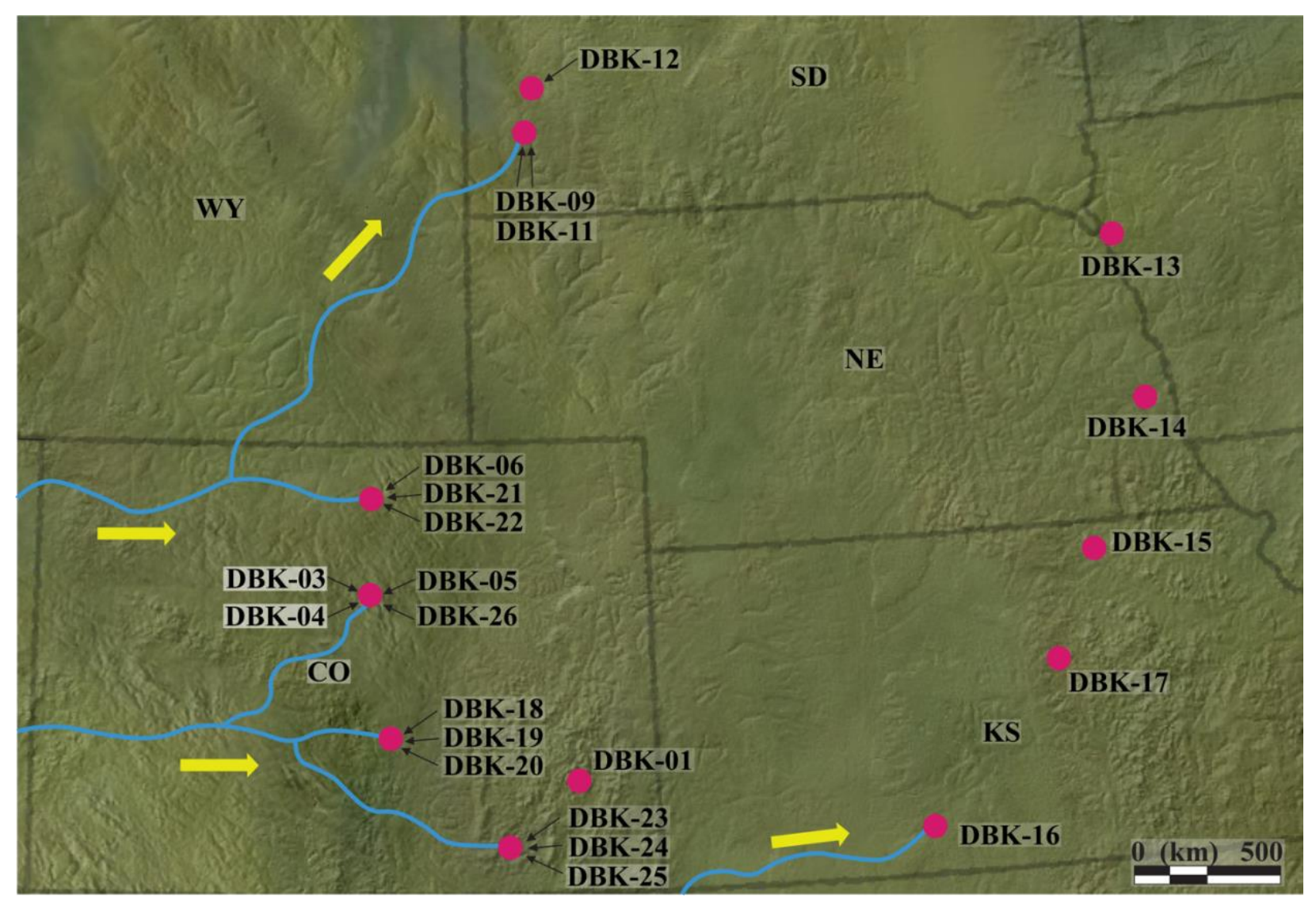

Figure 23: Paleodrainage reconstruction of the study area during deposition of the Lytle Formation (and equivalents), represented on a Blakey map from the Aptian (125-120 Ma). Yellow arrows point in the direction of flow. 


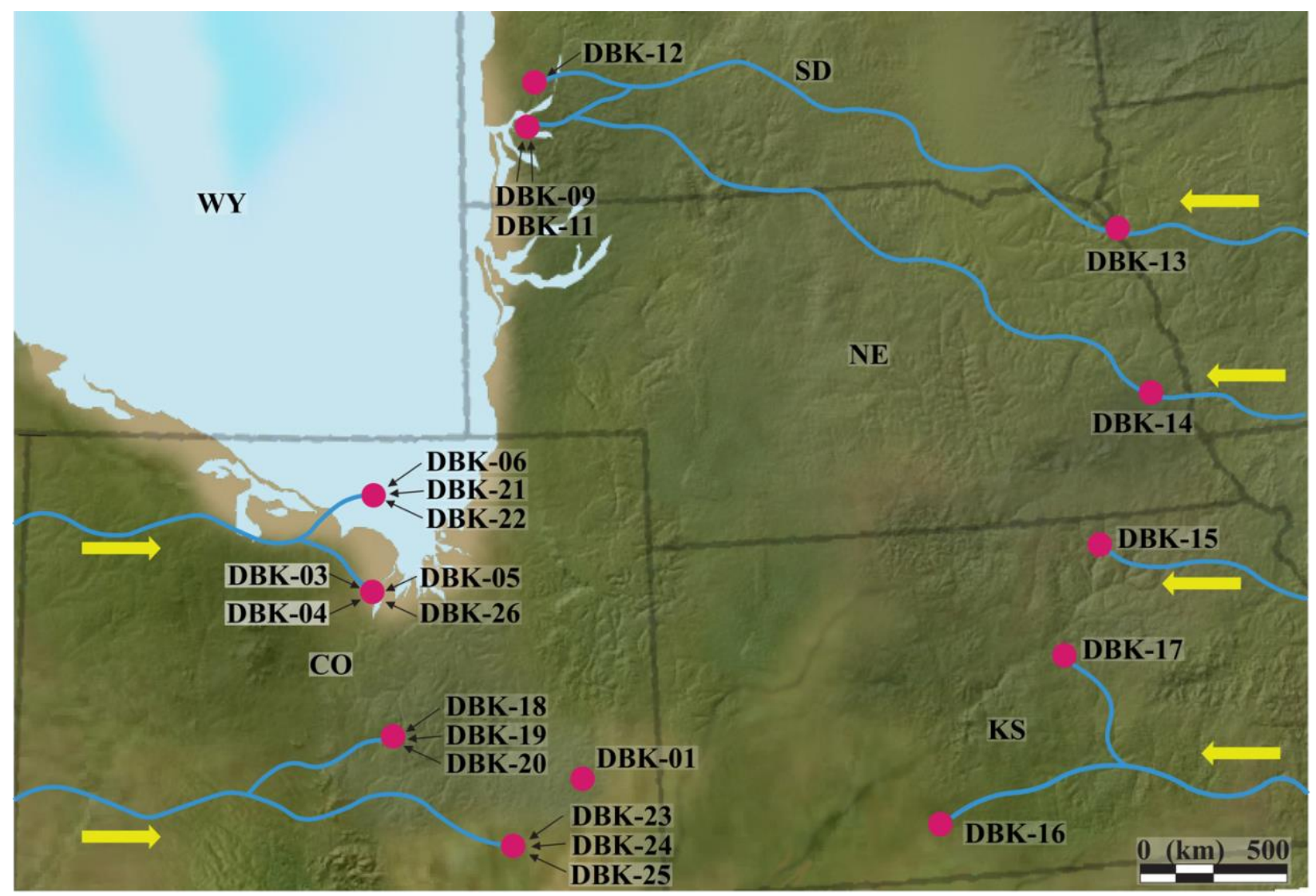

Figure 24: Paleodrainage reconstruction of the study area during deposition of the Dakota Formation, represented on a Blakey map from the late Albian/early Cenomanian (99-98.5 Ma). Yellow arrows point in the direction of flow. 


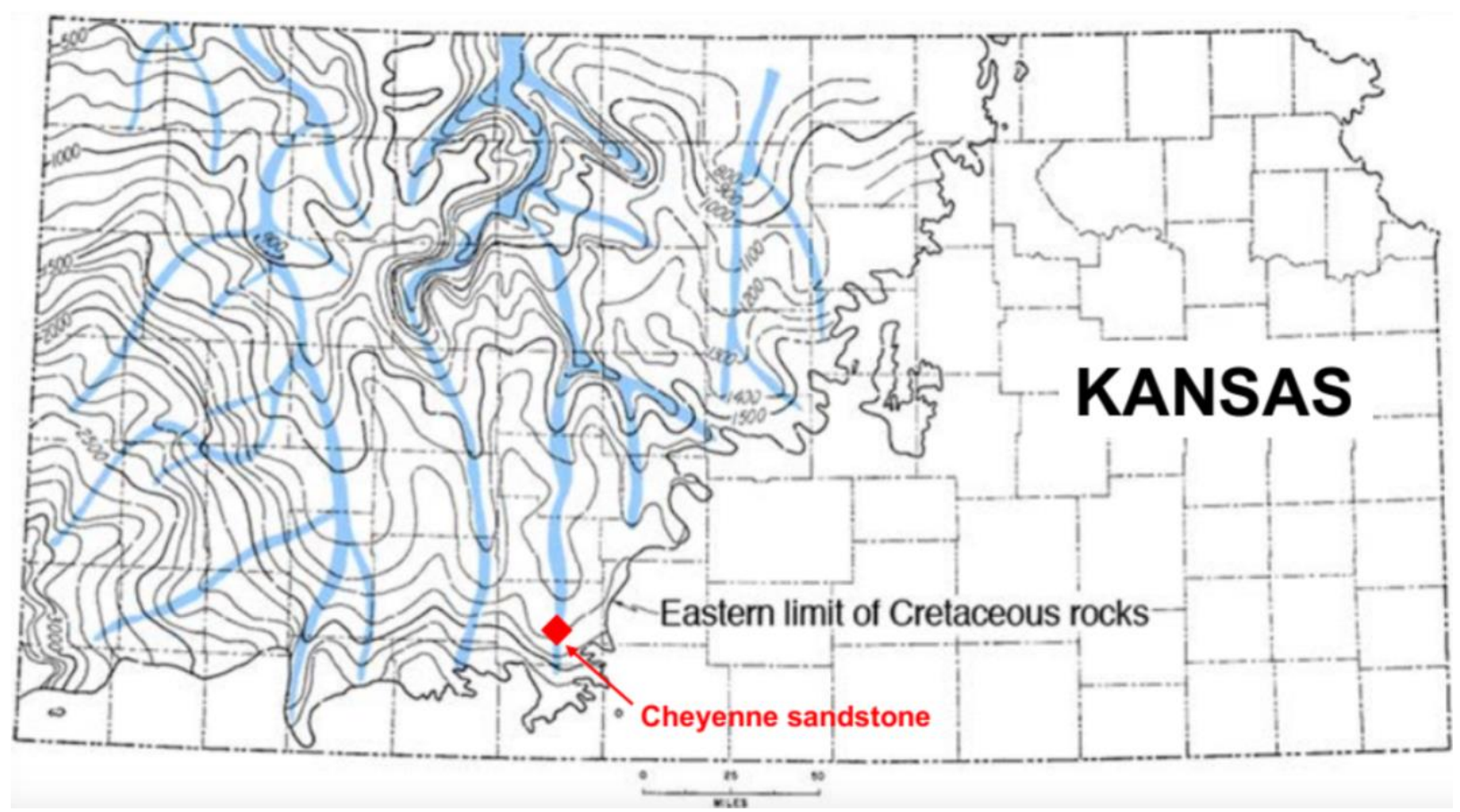

Figure 25: Interpretation of basal Cretaceous valleys in Kansas and their N-NW paleoflow. The Cheyenne sandstone label indicates the location of DBK-16 (from Merriam, 1962).

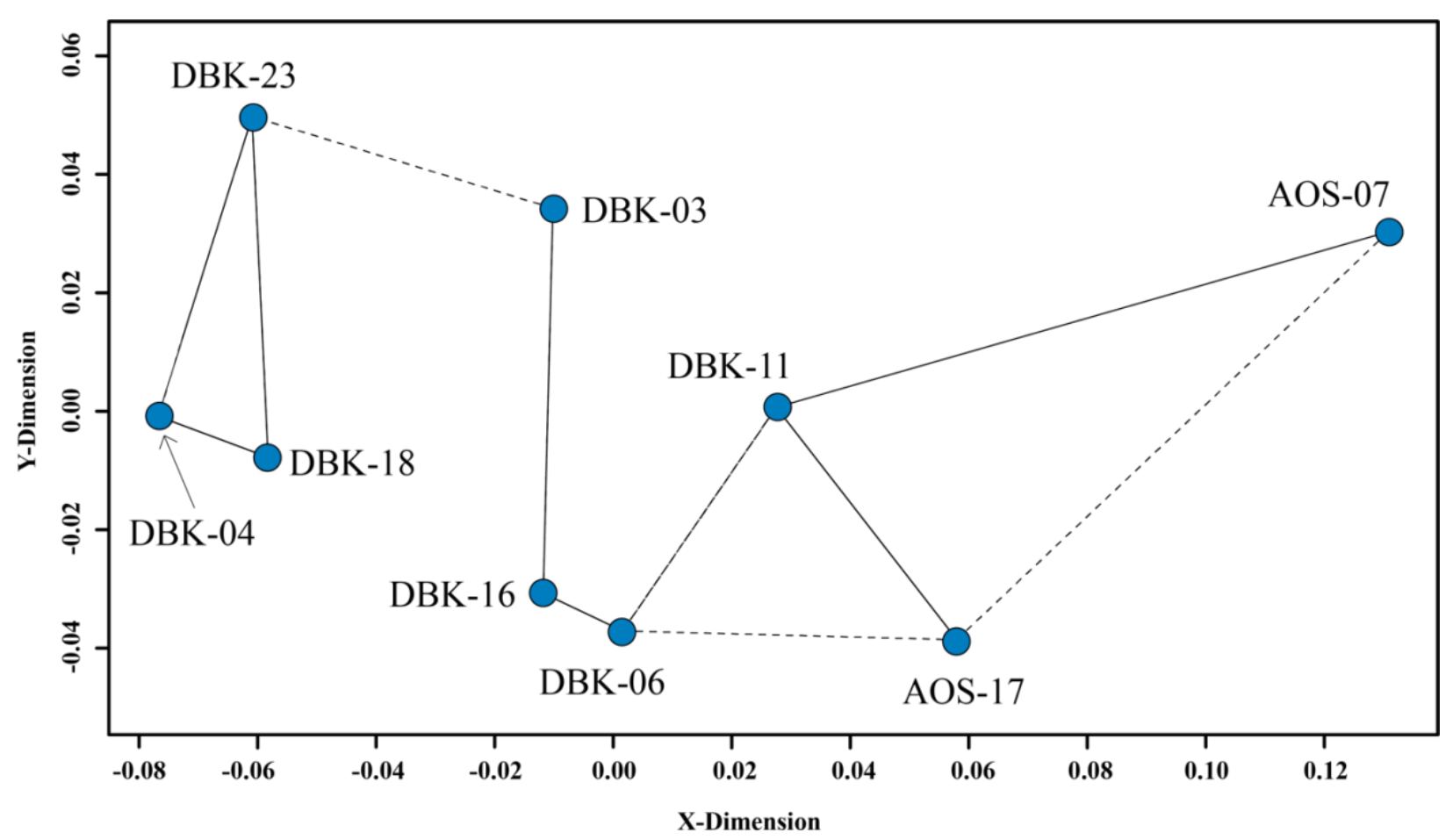

Figure 26: Two-dimensional MDS plot for Lytle Formation and age-equivalent samples (DBK), and the McMurray Formation samples from Cold Lake, Alberta (AOS). Solid lines connect the closest neighbors and dashed lines connect the second closest neighbors. 


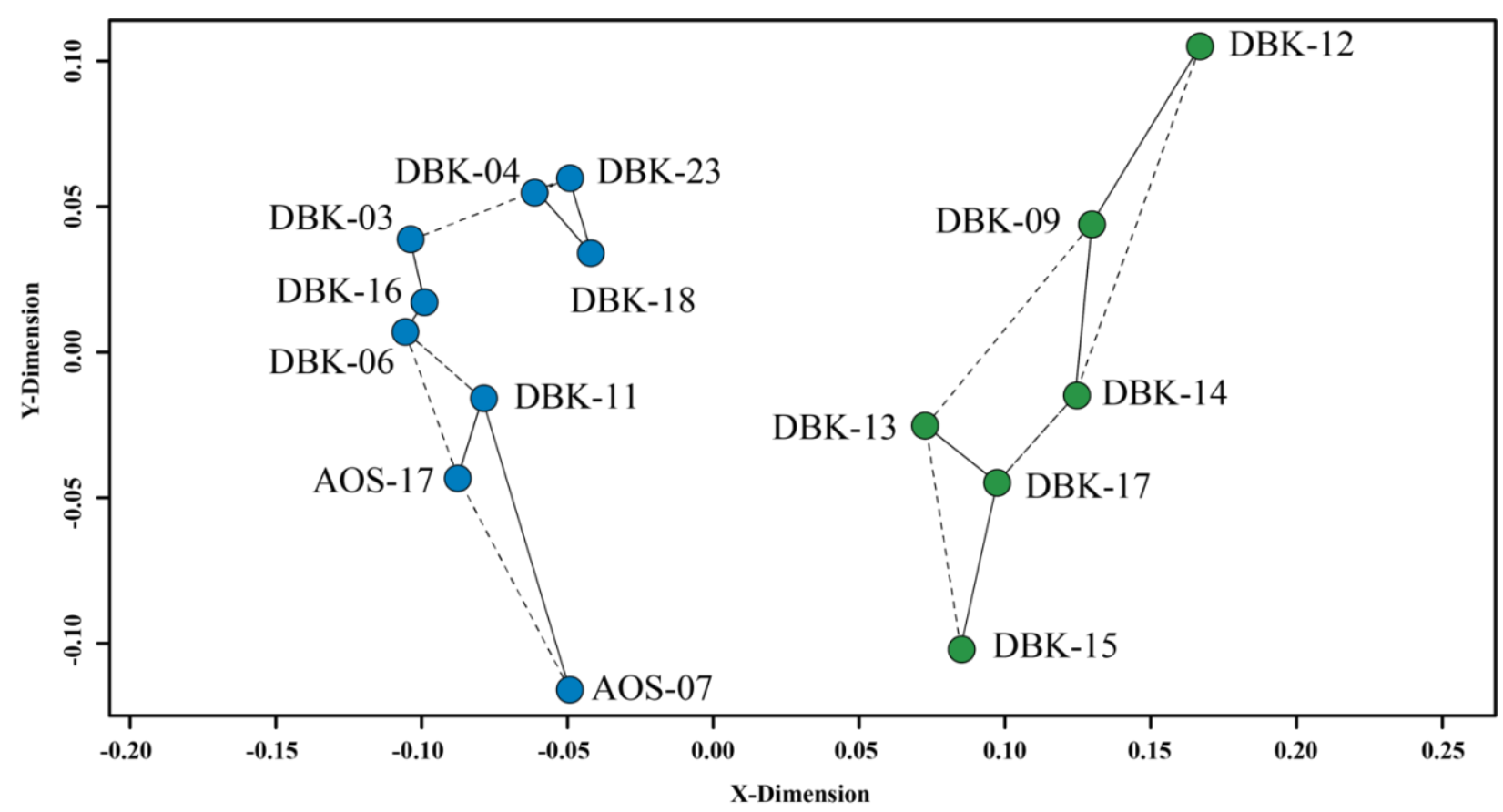

Figure 27: Two-dimensional MDS plot for the west-derived Lytle Formation and age-equivalent samples (DBK) and McMurray Formation samples (AOS) in blue, and the east-derived Dakota Formation samples in green. Solid lines connect the closest neighbors and dashed lines connect the second closest neighbors. 


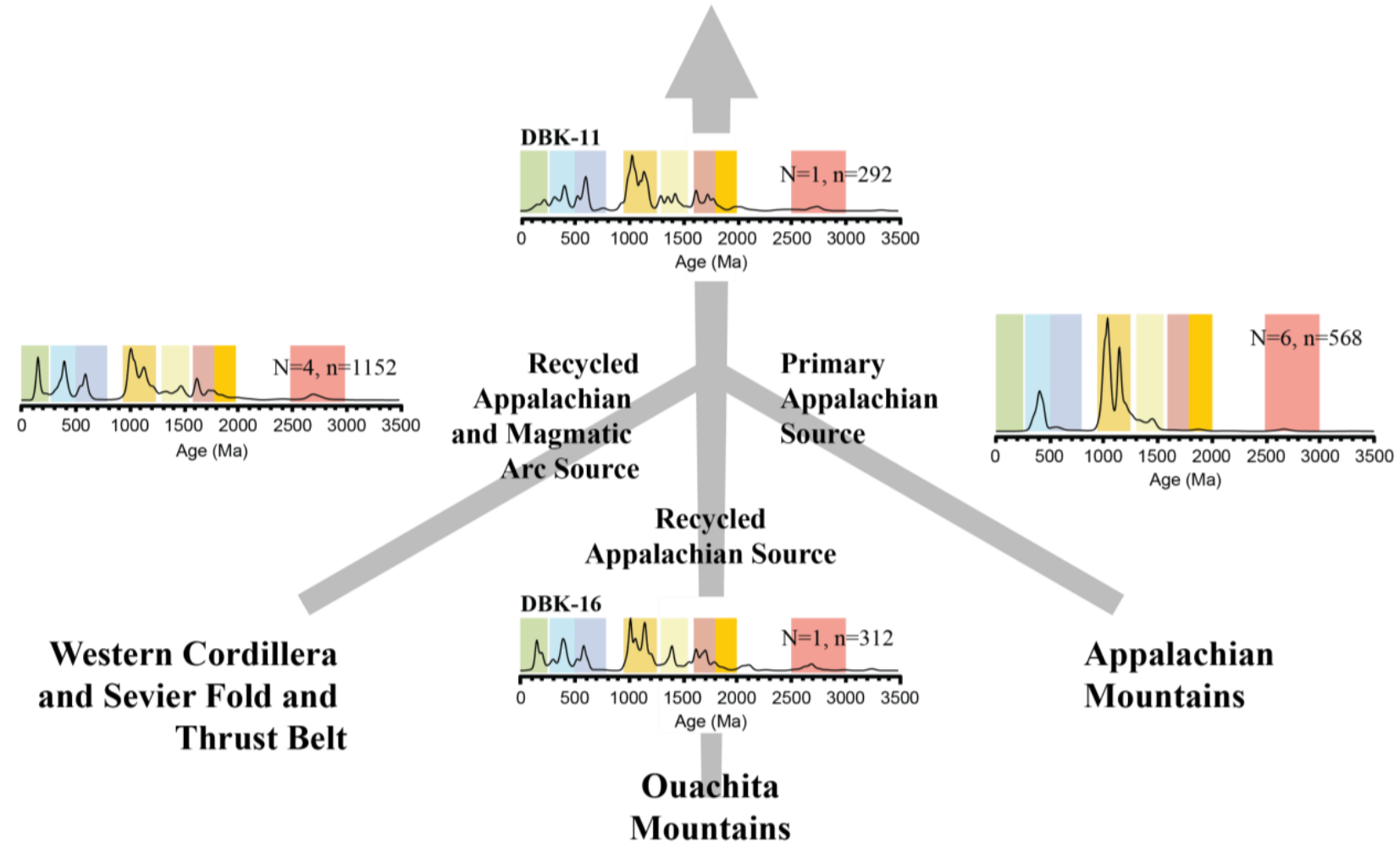

Figure 28: General model for paleodrainage and sediment routing patterns during the Early Cretaceous. 


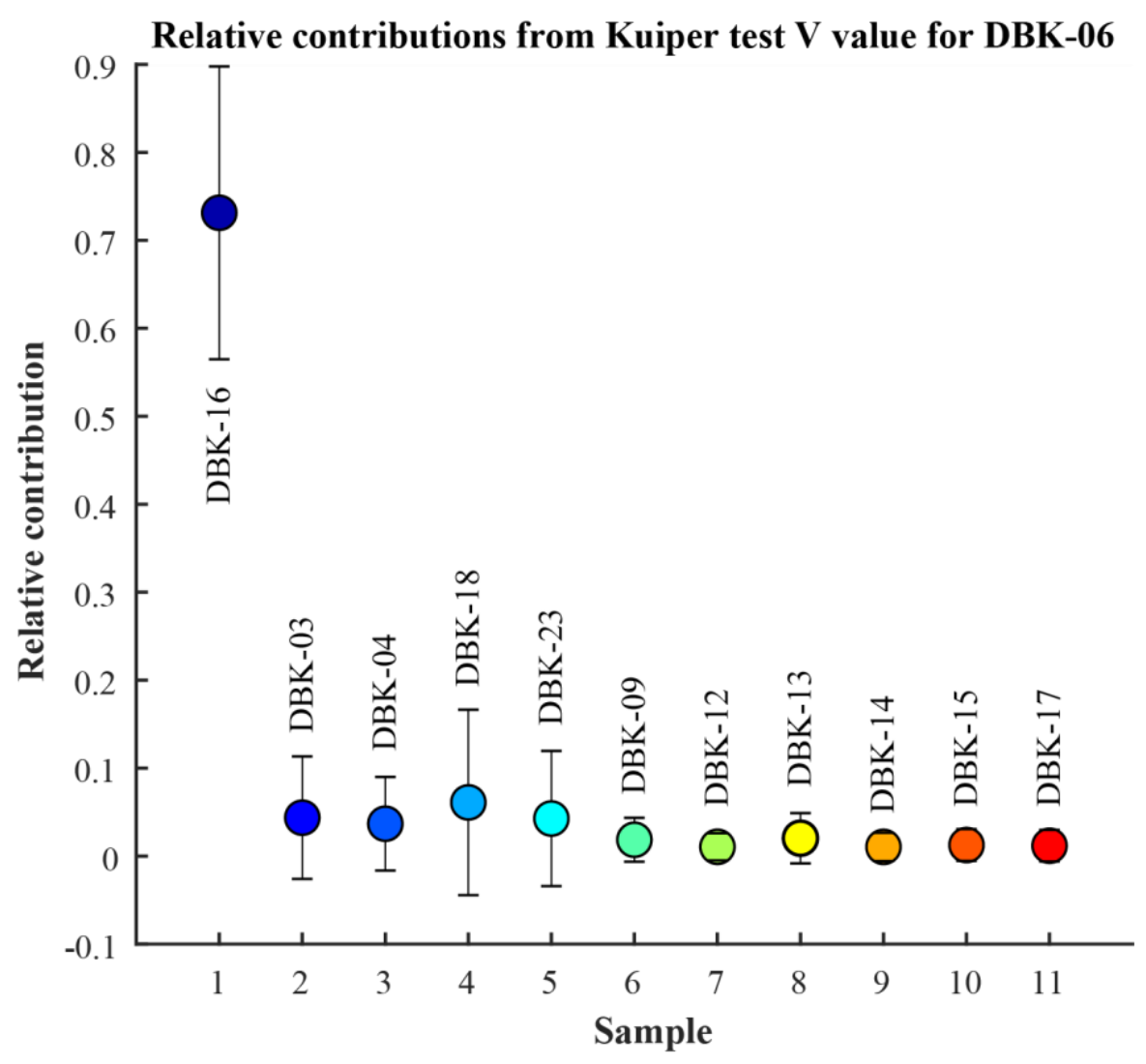

Figure 29: Relative contributions of potential parent sources for DBK-06 based on the Kuiper V statistic. 


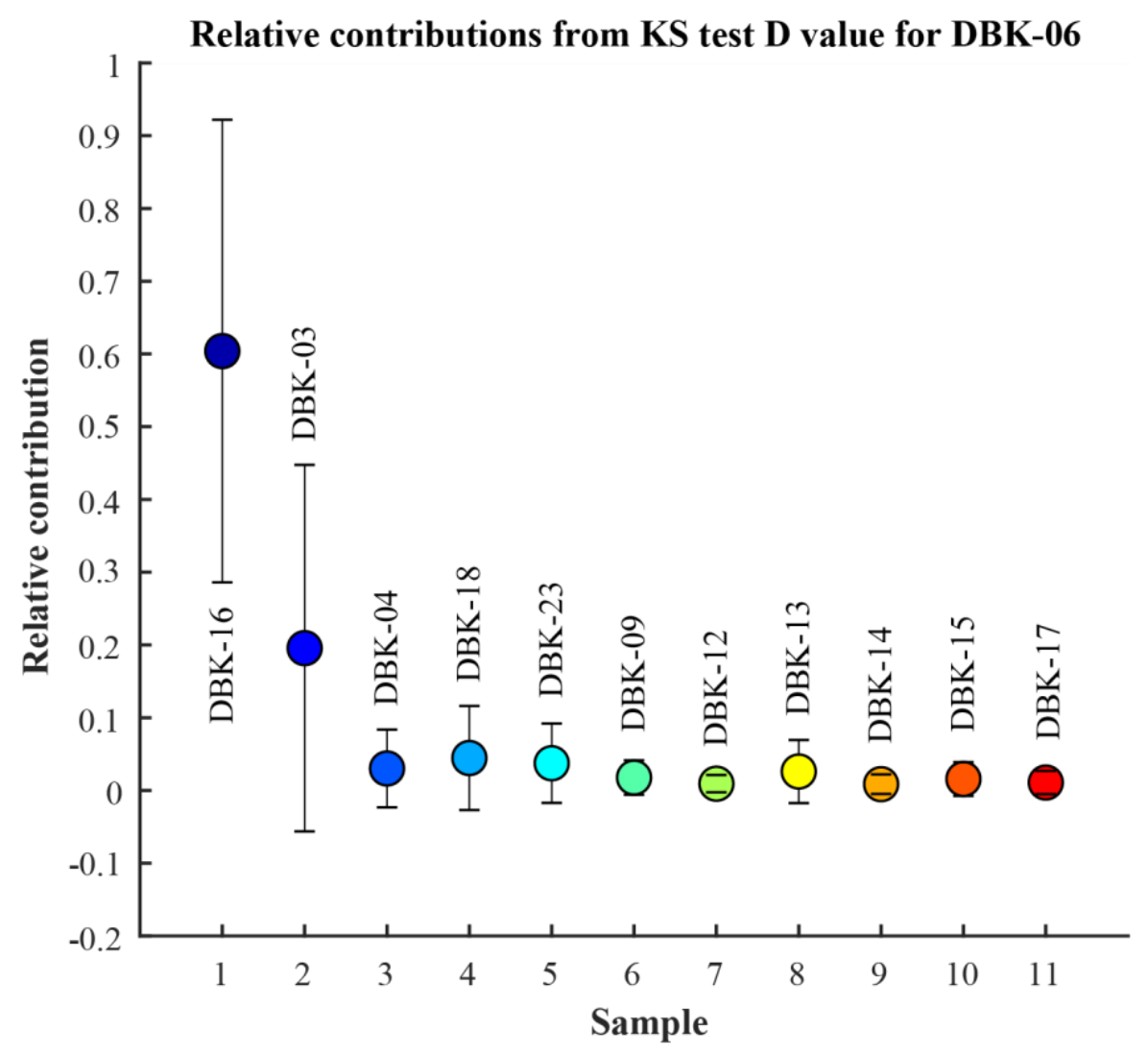

Figure 30: Relative contributions of potential parent sources for DBK-06 based on the KS D statistic. 


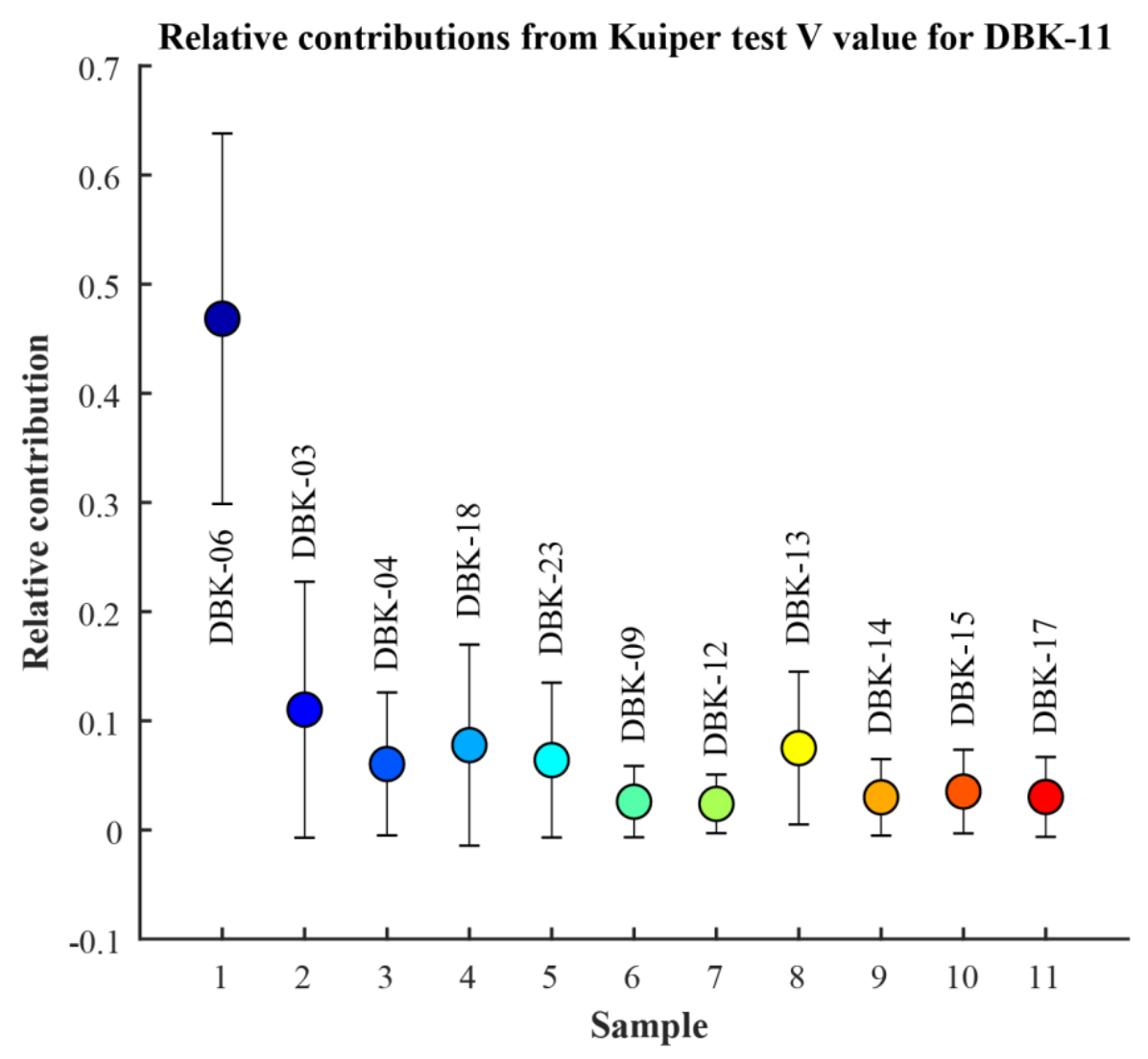

Figure 31: Relative contributions of potential parent sources for DBK-11 based on the Kuiper V statistic. 


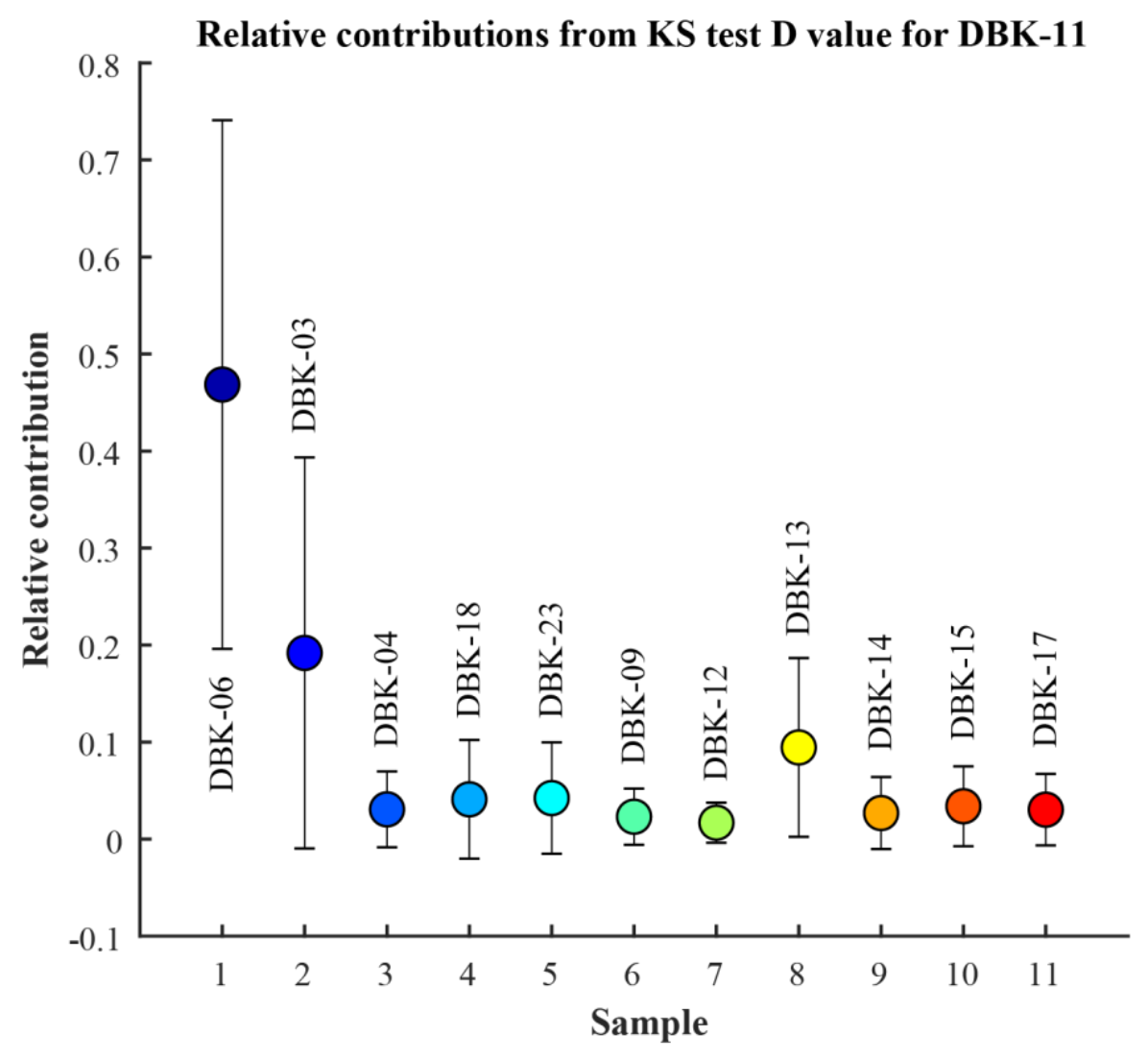

Figure 32: Relative contributions of potential parent sources for DBK-11 based on the KS D statistic. 


\section{Tables}

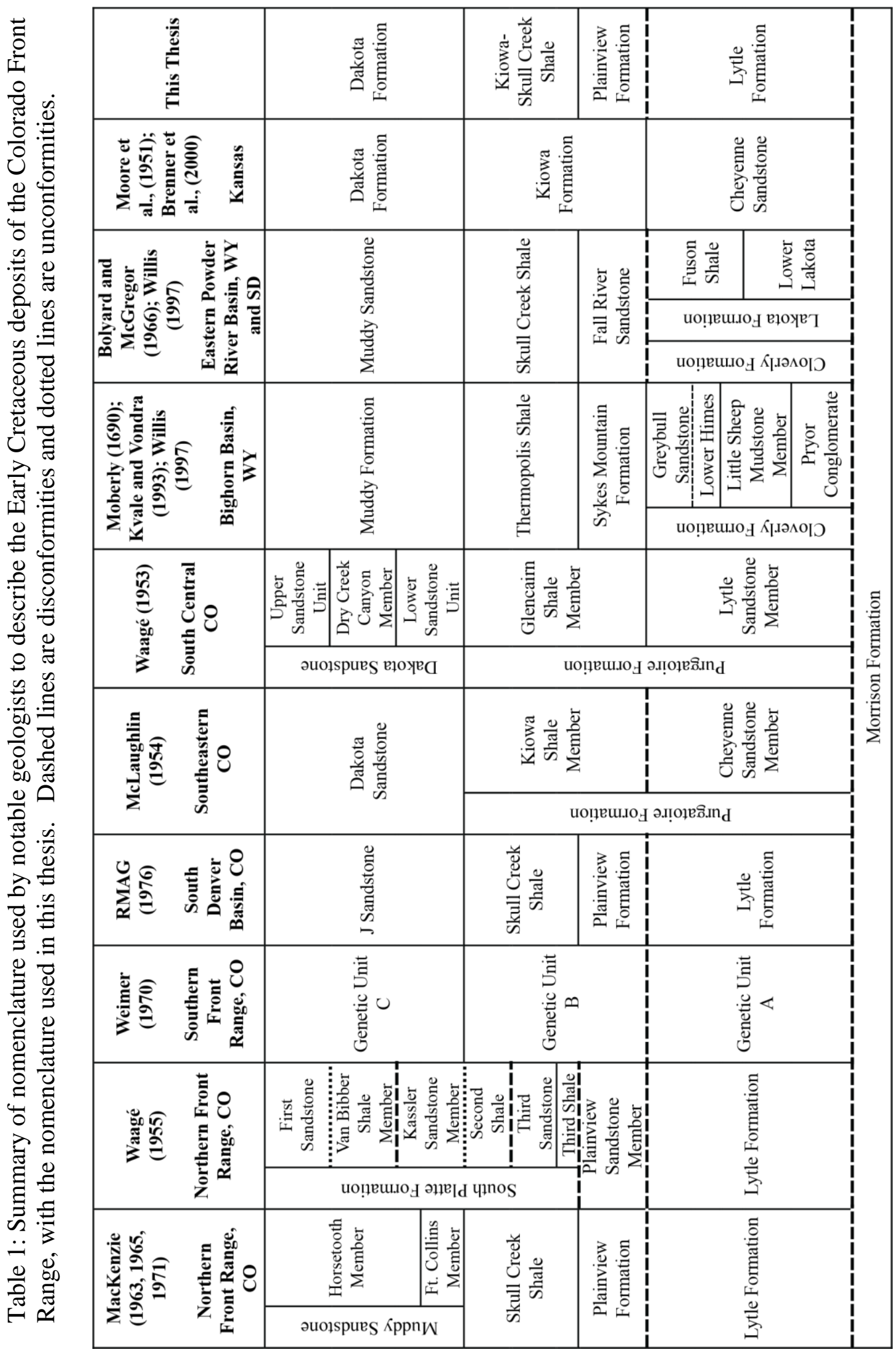


Table 2: Primary source and potential recycled locations for the DZ U-Pb populations present in this study. (From Blum et al., 2017 and summarized from: Becker et al., 2005; Whitmeyer and Karlstrom, 2007; Dickinson and Gehrels, 2009; Park et al., 2010; Laskowski et al., 2013).

\begin{tabular}{|c|c|c|c|}
\hline $\begin{array}{l}\text { Population } \\
\text { Name }\end{array}$ & Age Range & Primary Protolith Source & $\begin{array}{l}\text { Common geographic } \\
\text { and stratigraphic } \\
\text { sources for reworked } \\
\text { population } \\
\end{array}$ \\
\hline $\begin{array}{l}\text { Laramide and } \\
\text { post-Laramide } \\
\text { volcanics } \\
\end{array}$ & 80-0 Ma & $\begin{array}{l}\text { U.S. Rocky Mountains, Great } \\
\text { Basin, Mexican Sierra Madre } \\
\text { Occidental }\end{array}$ & $\begin{array}{l}\text { Possible reworking from } \\
\text { ashfall blankets associated } \\
\text { with volcanic centers }\end{array}$ \\
\hline $\begin{array}{l}\text { Mesozoic } \\
\text { Western } \\
\text { Cordillera }\end{array}$ & 275-0 Ma & $\begin{array}{l}\text { Mesozoic magmatic arc, Baja } \\
\text { California and Sonora of } \\
\text { Mexico, Sierra Nevada of } \\
\text { California, Idaho }\end{array}$ & $\begin{array}{c}\text { Mesozoic foreland-basin } \\
\text { strata of the U.S. Western } \\
\text { Interior }\end{array}$ \\
\hline $\begin{array}{c}\text { Paleozoic } \\
\text { Appalachian }\end{array}$ & $\begin{array}{c}500-290 \\
\mathrm{Ma}\end{array}$ & $\begin{array}{l}\text { Appalachian-Ouachita } \\
\text { cordillera }\end{array}$ & $\begin{array}{l}\text { Paleozoic Appalachian- } \\
\text { Ouachita foreland-basin } \\
\text { strata, Paleozoic passive } \\
\text { margin strata of the } \\
\text { western U.S. }\end{array}$ \\
\hline $\begin{array}{l}\text { Neoproterozoic } \\
\text { Peri-Gondwanan } \\
\text { terranes, lapetus } \\
\text { Rift, Wichita } \\
\text { Mountains } \\
\end{array}$ & $\begin{array}{c}800-500 \\
\mathrm{Ma}\end{array}$ & $\begin{array}{l}\text { Gondwanan margin of the } \\
\text { Appalachian-Ouachita } \\
\text { cordillera, Wichita Mountains } \\
\text { of Oklahoma }\end{array}$ & $\begin{array}{l}\text { Appalachian-Ouachita } \\
\text { foreland-basin strata, } \\
\text { Paleozoic passive margin } \\
\text { strata of the western U.S. }\end{array}$ \\
\hline $\begin{array}{l}\text { Mesoproterozoic } \\
\text { Grenville }\end{array}$ & $\begin{array}{l}1250-950 \\
\mathrm{Ma}\end{array}$ & $\begin{array}{c}\text { Appalachian cordillera, } \\
\text { extending into central and } \\
\text { western Texas and northwestern } \\
\text { Mexico }\end{array}$ & $\begin{array}{l}\text { Paleozoic sandstones of } \\
\text { the U.S. midcontinent, } \\
\text { Appalachian-Ouachita } \\
\text { foreland-basin strata, } \\
\text { Paleozoic passive margin } \\
\text { strata of the western U.S. }\end{array}$ \\
\hline $\begin{array}{l}\text { Mesoproterozoic } \\
\text { Midcontinent } \\
\text { granite-rhyolite } \\
\text { province }\end{array}$ & $\begin{array}{c}1550-1300 \\
\mathrm{Ma}\end{array}$ & $\begin{array}{l}\text { Northeast-southwest trend } \\
\text { across the eastern U.S. } \\
\text { midcontinent, plus numerous } \\
\text { intrusions into Yavapai- } \\
\text { Mazatzal basement in the } \\
\text { Rocky Mountains }\end{array}$ & $\begin{array}{l}\text { Paleozoic sandstones of } \\
\text { the U.S. midcontinent, } \\
\text { Appalachian-Ouachita } \\
\text { foreland-basin strata, } \\
\text { Paleozoic passive margin } \\
\text { strata of the western U.S. }\end{array}$ \\
\hline $\begin{array}{l}\text { Paleoproterozoic } \\
\text { Yavapai- } \\
\text { Mazatzal orogens }\end{array}$ & $\begin{array}{c}1800-1600 \\
\mathrm{Ma}\end{array}$ & $\begin{array}{l}\text { Northeast-southwest trend } \\
\text { across the central U.S. } \\
\text { midcontinent to the } \\
\text { southwestern U.S., including } \\
\text { the central and southern } \\
\text { Laramide Rockies and the } \\
\text { Mogollon Rim of central } \\
\text { Arizona }\end{array}$ & $\begin{array}{l}\text { Paleozoic passive margin } \\
\text { strata of the western U.S. }\end{array}$ \\
\hline
\end{tabular}




\begin{tabular}{|c|c|c|c|}
\hline $\begin{array}{c}\text { Paleoproterozoic } \\
\begin{array}{c}\text { Penokean/Trans- } \\
\text { Hudson orogen }\end{array}\end{array}$ & $\begin{array}{c}2000-1800 \\
\mathrm{Ma}\end{array}$ & $\begin{array}{c}\text { South-central Canada } \\
\text { (Manitoba and Saskatchewan) } \\
\text { and the Great Lakes region of } \\
\text { the U.S. (especially Wisconsin) }\end{array}$ & $\begin{array}{c}\text { Common in low } \\
\text { concentrations throughout } \\
\text { the area, and in all } \\
\text { stratigraphic units }\end{array}$ \\
\hline $\begin{array}{c}\text { Archean } \\
\text { Wyperior and } \\
\text { Wyoming } \\
\text { provinces, others }\end{array}$ & $>2500 \mathrm{Ma}$ & $\begin{array}{c}\text { Northern U.S. midcontinent to } \\
\text { present-day northern Rocky } \\
\text { Mountains province }\end{array}$ & $\begin{array}{c}\text { Common in low } \\
\text { concentrations throughout } \\
\text { the area, and in all } \\
\text { stratigraphic units }\end{array}$ \\
\hline
\end{tabular}


Table 3: DBK sample set with sample numbers, corresponding stratigraphic unit, location, and the number of zircon grains in the sample.

\begin{tabular}{|c|c|c|c|c|c|}
\hline Sample & Location & Unit & Longitude & Latitude & Grain \\
\hline DBK-01 & John Martin & Dakota & -102.937367 & 38.076495 & 368 \\
\hline DBK-03 & I-70 & Plainview & -105.201656 & 39.701481 & 375 \\
\hline DBK-04 & I-70 & Lytle & -105.201742 & 39.701384 & 269 \\
\hline DBK-05 & I-70 & Morrison & -105.201789 & 39.701345 & 296 \\
\hline DBK-06 & Horsetooth & Lytle & -105.141649 & 40.528201 & 286 \\
\hline DBK-09 & Red Canyon & Dakota & -103.782778 & 43.371389 & 94 \\
\hline DBK-11 & Rapid City & Lakota/Lytle & -103.239571 & 44.109671 & 292 \\
\hline DBK-12 & Rapid City & Dakota & -103.239571 & 44.109671 & 96 \\
\hline DBK-13 & Dakota City & Dakota & -96.521164 & 42.364101 & 393 \\
\hline DBK-14 & Ashland & Dakota & -96.307412 & 41.031764 & 100 \\
\hline DBK-15 & Washington & Dakota & -96.995833 & 39.813056 & 98 \\
\hline DBK-16 & Belvidere & Cheyenne/Lytle & -99.091240 & 37.454995 & 312 \\
\hline DBK-17 & Salina & Dakota & -97.491759 & 38.906721 & 95 \\
\hline DBK-18 & Penrose & Lytle & -104.956580 & 38.500034 & 297 \\
\hline DBK-19 & Penrose & Dakota & -104.962485 & 38.488053 & 299 \\
\hline DBK-20 & Penrose & Morrison & -104.964996 & 38.526103 & 306 \\
\hline DBK-21 & Horsetooth & Morrison & -105.144360 & 40.526232 & 302 \\
\hline DBK-22 & Horsetooth & Dakota (Muddy) & -105.138365 & 40.528905 & 288 \\
\hline DBK-23 & Purgatoire & Lytle & -103.531373 & 37.695969 & 300 \\
\hline DBK-24 & Purgatoire & Dakota & -103.531373 & 37.695969 & 305 \\
\hline DBK-25 & Purgatoire & Morrison & -103.511046 & 37.715024 & 283 \\
\hline DBK-26 & I-70 & Dakota & -105.201180 & 39.701919 & 302 \\
\hline
\end{tabular}


Table 4: Summary of MDAs and youngest grains for each sample.

\begin{tabular}{|c|c|c|c|c|c|}
\hline Sample & Unit & $\begin{array}{c}\text { Youngest } \\
\text { Grain (Ma) } \\
\text { with } 1 \sigma \\
\end{array}$ & $\begin{array}{c}\text { Calculated } \\
\text { MDA (Ma) } \\
\text { with } 2 \sigma \\
\end{array}$ & Ages (Ma) & $\begin{array}{c}1 \sigma \\
\text { Uncertainty } \\
(\mathrm{Ma})\end{array}$ \\
\hline DBK-05 & Morrison at I-70 & $147.4 \pm 2.7$ & $148.7 \pm 2.3$ & $\begin{array}{l}147.4 \\
147.8 \\
148.2 \\
149.1 \\
149.1 \\
149.2 \\
149.5 \\
149.8 \\
\end{array}$ & $\begin{array}{l}2.7 \\
2.0 \\
2.3 \\
1.5 \\
3.1 \\
3.0 \\
2.7 \\
5.1 \\
\end{array}$ \\
\hline DBK-20 & $\begin{array}{l}\text { Morrison at } \\
\text { Penrose }\end{array}$ & $145.0 \pm 3.3$ & $147.6 \pm 3.1$ & $\begin{array}{l}145.0 \\
146.3 \\
147.6 \\
148.0 \\
148.2 \\
148.3 \\
148.7\end{array}$ & $\begin{array}{l}3.3 \\
5.5 \\
4.8 \\
5.6 \\
2.4 \\
4.7 \\
2.8 \\
\end{array}$ \\
\hline DBK-21 & $\begin{array}{l}\text { Morrison at } \\
\text { Horsetooth }\end{array}$ & $164.1 \pm 2.6$ & Lack of & ing volcanog & ic grains \\
\hline DBK-25 & $\begin{array}{l}\text { Morrison at } \\
\text { Purgatoire }\end{array}$ & $148.4 \pm 2.4$ & $149.6 \pm 2.5$ & $\begin{array}{l}148.4 \\
148.7 \\
149.4 \\
149.5 \\
149.8 \\
150.6 \\
150.6 \\
\end{array}$ & $\begin{array}{l}2.4 \\
2.7 \\
3.3 \\
2.3 \\
2.5 \\
2.5 \\
2.3 \\
\end{array}$ \\
\hline DBK-04 & Lytle at I-70 & $152.6 \pm 8.1$ & \multicolumn{3}{|c|}{ Lack of young volcanogenic grains } \\
\hline DBK-06 & $\begin{array}{c}\text { Lytle at } \\
\text { Horsetooth }\end{array}$ & $146.1 \pm 4.2$ & \multicolumn{3}{|c|}{ Lack of young volcanogenic grains } \\
\hline DBK-11 & $\begin{array}{c}\text { Lakota (Lytle) at } \\
\text { Red Canyon } \\
\end{array}$ & $134.6 \pm 1.7$ & \multicolumn{3}{|c|}{ Lack of young volcanogenic grains } \\
\hline DBK-16 & $\begin{array}{c}\text { Cheyenne (Lytle) } \\
\text { at Belvidere }\end{array}$ & $122.9 \pm 2.1$ & \multicolumn{3}{|c|}{ Lack of young volcanogenic grains } \\
\hline DBK-18 & Lytle at Penrose & $145.3 \pm 4.8$ & \multicolumn{3}{|c|}{ Lack of young volcanogenic grains } \\
\hline DBK-23 & Lytle at Purgatoire & $146.5 \pm 2.5$ & \multicolumn{3}{|c|}{ Lack of young volcanogenic grains } \\
\hline DBK-03 & Plainview at I-70 & $146.8 \pm 3.8$ & \multicolumn{3}{|c|}{ Lack of young volcanogenic grains } \\
\hline DBK-09 & $\begin{array}{c}\text { Dakota at Red } \\
\text { Canyon }\end{array}$ & $323.7 \pm 16.8$ & \multicolumn{3}{|c|}{ Lack of young volcanogenic grains } \\
\hline DBK-12 & $\begin{array}{l}\text { Dakota at Rapid } \\
\text { City }\end{array}$ & $319.9 \pm 2.3$ & \multicolumn{3}{|c|}{ Lack of young volcanogenic grains } \\
\hline DBK-13 & $\begin{array}{c}\text { Dakota at Dakota } \\
\text { City } \\
\end{array}$ & $385.0 \pm 16.4$ & \multicolumn{3}{|c|}{ Lack of young volcanogenic grains } \\
\hline DBK-14 & Dakota at Ashland & $351.9 \pm 4.1$ & \multicolumn{3}{|c|}{ Lack of young volcanogenic grains } \\
\hline
\end{tabular}




\begin{tabular}{|c|c|c|c|c|c|}
\hline DBK-15 & $\begin{array}{c}\text { Dakota at } \\
\text { Washington }\end{array}$ & $390.2 \pm 4.6$ & \multicolumn{3}{|c|}{ Lack of young volcanogenic grains } \\
\hline DBK-17 & Dakota at Salina & $364.2 \pm 3.0$ & \multicolumn{3}{|c|}{ Lack of young volcanogenic grains } \\
\hline DBK-01 & $\begin{array}{c}\text { Dakota at John } \\
\text { Martin }\end{array}$ & $96.2 \pm 2.2$ & $96.2 \pm 4.3$ & $\begin{array}{l}96.2 \\
96.7\end{array}$ & $\begin{array}{l}2.2 \\
5.2\end{array}$ \\
\hline DBK-19 & Dakota at Penrose & $97.4 \pm 2.0$ & $98.1 \pm 1.9$ & $\begin{array}{l}97.4 \\
97.8 \\
97.9 \\
98.1 \\
98.3 \\
98.5 \\
98.6 \\
\end{array}$ & $\begin{array}{l}2.0 \\
1.9 \\
2.5 \\
2.0 \\
2.3 \\
3.2 \\
1.7\end{array}$ \\
\hline DBK-22 & $\begin{array}{l}\text { Dakota at } \\
\text { Horsetooth }\end{array}$ & $98.9 \pm 1.1$ & $99.6 \pm 1.6$ & $\begin{array}{c}98.9 \\
99.6 \\
99.9 \\
99.9 \\
100.0\end{array}$ & $\begin{array}{l}1.1 \\
1.6 \\
1.9 \\
1.3 \\
1.1\end{array}$ \\
\hline DBK-24 & $\begin{array}{l}\text { Dakota at } \\
\text { Purgatoire }\end{array}$ & $150.5 \pm 3.6$ & \multicolumn{3}{|c|}{ Lack of young volcanogenic grains } \\
\hline DBK-26 & Dakota at I-70 & $96.7 \pm 1.9$ & $99.2 \pm 1.7$ & $\begin{array}{c}96.7 \\
98.3 \\
98.6 \\
99.4 \\
99.6 \\
99.6 \\
99.8 \\
99.8 \\
99.9 \\
100.0 \\
100.3 \\
100.6\end{array}$ & $\begin{array}{l}1.9 \\
2.6 \\
2.2 \\
2.3 \\
2.6 \\
2.3 \\
2.4 \\
1.9 \\
2.5 \\
2.5 \\
3.1 \\
2.6\end{array}$ \\
\hline
\end{tabular}


Table 5: Measurements of unit thickness in meters. Values for the Morrison and Dakota formations are often minimums where the entire unit may not be exposed.

\begin{tabular}{|l|l|l|l|l|l|}
\hline \multicolumn{1}{|c|}{ Unit } & $\begin{array}{c}\text { Horsetooth } \\
\text { Reservoir }\end{array}$ & $\begin{array}{c}\text { I-70 } \\
\text { Morrison }\end{array}$ & $\begin{array}{c}\text { Dinosaur } \\
\text { Ridge }\end{array}$ & $\begin{array}{c}\text { U.S. Highway } \\
\mathbf{2 8 5}\end{array}$ & Skyline Drive \\
\hline Morrison & 4 & 104 & 21 & 24 & 70 \\
\hline Lytle & 26 & 32 & 11 & 30 & 8 \\
\hline Plainview & 9 & 15 & 11 & 11 & 5 \\
\hline KSCS & 44 & 5 & 1.5 & 20 & 16 \\
\hline Dakota & 21 & 37 & 20 & 35 & 3 \\
\hline
\end{tabular}

Table 6: Measurements of thicknesses of inclined-strata sets with their respective internal dip angle.

\begin{tabular}{|c|c|c|c|c|}
\hline Unit & $\begin{array}{c}\text { Thickness of } \\
\text { Inclined-Strata Sets }(\mathbf{m})\end{array}$ & $\begin{array}{c}\text { Internal Dip Angle of } \\
\text { Inclined-Strata Sets } \mathbf{(}^{\circ}\end{array}$ & Longitude & Latitude \\
\hline Lytle & 17.4 & 6 & -105.141649 & 40.528201 \\
\hline Lytle & 11.1 & 6 & -105.141128 & 40.528127 \\
\hline Lytle & 15.2 & 8 & -105.201742 & 39.701384 \\
\hline Lytle & 20.1 & 7 & -105.102719 & 39.380644 \\
\hline Lytle & 10.4 & 6 & -104.956580 & 38.500034 \\
\hline Plainview & 12.7 & 7 & -105.201656 & 39.701481 \\
\hline Plainview & 11.1 & 7 & -105.170471 & 39.634559 \\
\hline Plainview & 10.6 & 10 & -105.193205 & 39.676227 \\
\hline Plainview & 5.1 & 6 & -104.961579 & 38.489630 \\
\hline Dakota & 8.7 & 16 & -105.201416 & 39.704186 \\
\hline Dakota & 9.2 & 12 & -105.192391 & 39.675863 \\
\hline
\end{tabular}


Table 7: Measurements of mean cross-bed thicknesses with the respective calculated mean bedform height and river flow depth.

\begin{tabular}{|c|c|c|c|c|c|}
\hline Unit & $\begin{array}{c}\text { Mean cross-bed } \\
\text { thickness (cm) }\end{array}$ & $\begin{array}{c}\text { Calculated } \\
\text { mean bedform } \\
\text { height }(\mathbf{m})\end{array}$ & $\begin{array}{c}\text { Calculated } \\
\text { river flow } \\
\text { depth (m) }\end{array}$ & Longitude & Latitude \\
\hline Morrison & 40 & 1.2 & 6.3 & -105.201789 & 39.701345 \\
\hline Morrison & 40 & 1.2 & 6.3 & -105.194017 & 39.677465 \\
\hline Morrison & 35 & 1.0 & 5.6 & -105.252594 & 38.464209 \\
\hline Morrison & 35 & 1.0 & 5.6 & -104.964996 & 38.526103 \\
\hline Lytle & 140 & 4.1 & 18.0 & -105.141649 & 40.528201 \\
\hline Lytle & 80 & 2.3 & 11.2 & -105.201742 & 39.701384 \\
\hline Lytle & 60 & 1.7 & 8.8 & -105.193533 & 39.676718 \\
\hline Lytle & 150 & 4.4 & 19.1 & -105.102719 & 39.380644 \\
\hline Lytle & 40 & 1.2 & 6.3 & -105.252474 & 38.463737 \\
\hline Lytle & 45 & 1.3 & 6.9 & -104.956580 & 38.500034 \\
\hline Lytle & 60 & 1.7 & 8.8 & -103.531373 & 37.695969 \\
\hline Lytle & 40 & 1.2 & 6.3 & -99.091240 & 37.454995 \\
\hline Plainview & 40 & 1.2 & 6.3 & -105.141264 & 40.528328 \\
\hline Plainview & 95 & 2.8 & 13.0 & -105.201656 & 39.701481 \\
\hline Plainview & 65 & 1.9 & 9.5 & -105.193205 & 39.676227 \\
\hline Plainview & 75 & 2.2 & 10.7 & -105.170471 & 39.634559 \\
\hline Dakota & 55 & 1.6 & 8.2 & -105.138365 & 40.528905 \\
\hline Dakota & 75 & 2.2 & 10.7 & -105.201180 & 39.701919 \\
\hline Dakota & 60 & 1.7 & 8.8 & -105.192391 & 39.675863 \\
\hline Dakota & 55 & 1.6 & 8.2 & -105.169847 & 39.635638 \\
\hline Dakota & 60 & 1.7 & 8.8 & -105.251214 & 38.461094 \\
\hline Dakota & 50 & 1.4 & 7.6 & -103.531373 & 37.695969 \\
\hline
\end{tabular}


Table 8: Percent relative contributions from the Kuiper V statistic, KS D statistic, and the mean of both with DBK-06 as the daughter mixed sample. The standard deviation $(2 \sigma)$ reported is from the top $1 \%$ of best fits.

\begin{tabular}{|c|c|c|c|c|c|}
\hline & \multicolumn{2}{|c|}{ Kuiper V Statistic } & \multicolumn{2}{|c|}{ KS D Statistic } & Mean \\
\hline Sample & $\begin{array}{l}\text { Percent } \\
\text { Relative } \\
\text { Contribution }\end{array}$ & $\begin{array}{l}\text { Standard } \\
\text { Deviation } \\
(2 \sigma)\end{array}$ & $\begin{array}{l}\text { Percent } \\
\text { Relative } \\
\text { Contribution }\end{array}$ & $\begin{array}{l}\text { Standard } \\
\text { Deviation } \\
(2 \sigma)\end{array}$ & $\begin{array}{l}\text { Percent } \\
\text { Relative } \\
\text { Contribution }\end{array}$ \\
\hline DBK-16 & 73.13 & 0.17 & 60.39 & 0.32 & 66.76 \\
\hline DBK-03 & 4.37 & 0.070 & 19.56 & 0.25 & 11.97 \\
\hline DBK-04 & 3.68 & 0.053 & 3.02 & 0.053 & 3.35 \\
\hline DBK-18 & 6.10 & 0.11 & 4.46 & 0.071 & 5.28 \\
\hline DBK-23 & 4.27 & 0.077 & 3.74 & 0.055 & 4.01 \\
\hline DBK-09 & 1.86 & 0.025 & 1.77 & 0.024 & 1.82 \\
\hline DBK-12 & 1.06 & 0.015 & 0.93 & 0.012 & 0.99 \\
\hline DBK-13 & 2.04 & 0.029 & 2.61 & 0.043 & 2.32 \\
\hline DBK-14 & 1.05 & 0.016 & 0.86 & 0.013 & 0.96 \\
\hline DBK-15 & 1.26 & 0.018 & 1.57 & 0.023 & 1.42 \\
\hline DBK-17 & 1.18 & 0.018 & 1.09 & 0.016 & 1.13 \\
\hline
\end{tabular}

Table 9: Percent relative contributions from the Kuiper V statistic, KS D statistic, and the mean of both with DBK-11 as the daughter mixed sample. The standard deviation $(2 \sigma)$ reported is from the top $1 \%$ of best fits.

\begin{tabular}{|l|l|l|l|l|l|}
\hline & \multicolumn{2}{l|}{ Kuiper V Statistic } & \multicolumn{2}{l|}{ KS D Statistic } & Mean \\
\hline Sample & $\begin{array}{l}\text { Percent } \\
\text { Relative } \\
\text { Contribution }\end{array}$ & $\begin{array}{l}\text { Standard } \\
\text { Deviation } \\
(\mathbf{2} \boldsymbol{\sigma})\end{array}$ & $\begin{array}{l}\text { Percent } \\
\text { Relative } \\
\text { Contribution }\end{array}$ & $\begin{array}{l}\text { Standard } \\
\text { Deviation } \\
(\mathbf{2 \sigma})\end{array}$ & $\begin{array}{l}\text { Percent } \\
\text { Relative } \\
\text { Contribution }\end{array}$ \\
\hline DBK-06 & 46.83 & 0.17 & 46.85 & 0.27 & 46.84 \\
\hline DBK-03 & 11.02 & 0.12 & 19.19 & 0.20 & 15.10 \\
\hline DBK-04 & 6.03 & 0.065 & 3.07 & 0.039 & 4.55 \\
\hline DBK-18 & 7.77 & 0.092 & 4.10 & 0.061 & 5.93 \\
\hline DBK-23 & 6.39 & 0.071 & 4.23 & 0.057 & 5.31 \\
\hline DBK-09 & 2.58 & 0.033 & 2.31 & 0.029 & 2.45 \\
\hline DBK-12 & 2.38 & 0.027 & 1.69 & 0.021 & 2.04 \\
\hline DBK-13 & 7.49 & 0.070 & 9.45 & 0.092 & 8.47 \\
\hline DBK-14 & 2.98 & 0.035 & 2.69 & 0.037 & 2.84 \\
\hline DBK-15 & 3.51 & 0.038 & 3.39 & 0.041 & 3.45 \\
\hline DBK-17 & 3.02 & 0.036 & 3.03 & 0.037 & 3.02 \\
\hline
\end{tabular}




\title{
10. Appendices
}

\author{
Appendix A: Measured Sections
}

\section{Measured Section Legend}

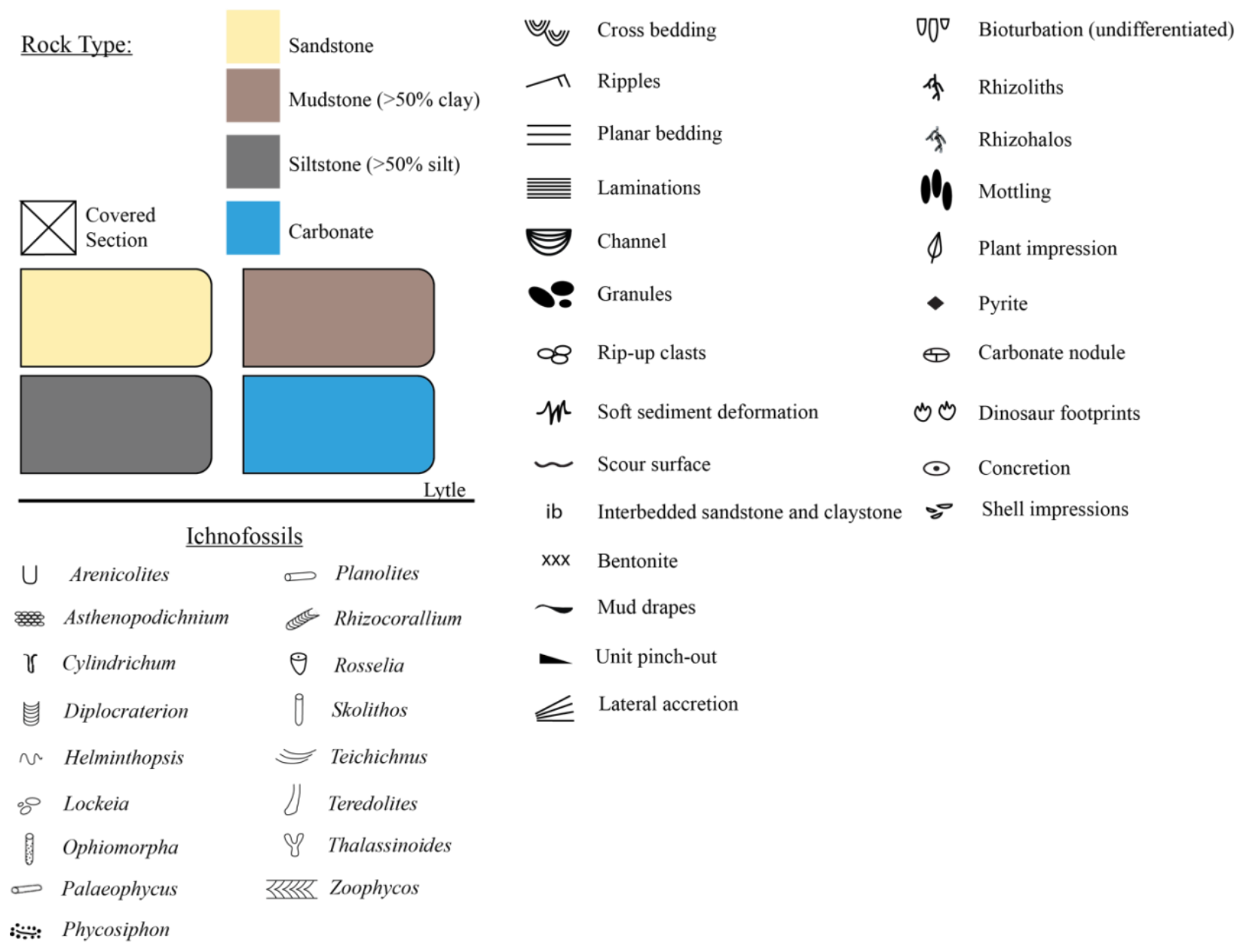

Appendix A1: Legend for lithologies, sedimentologic, and ichnologic features present within the Morrison, Lytle, Plainview, Kiowa-Skull Creek Shale, and Dakota formations. 


\section{Horsetooth Reservoir Spring Canyon Dam 1/2}
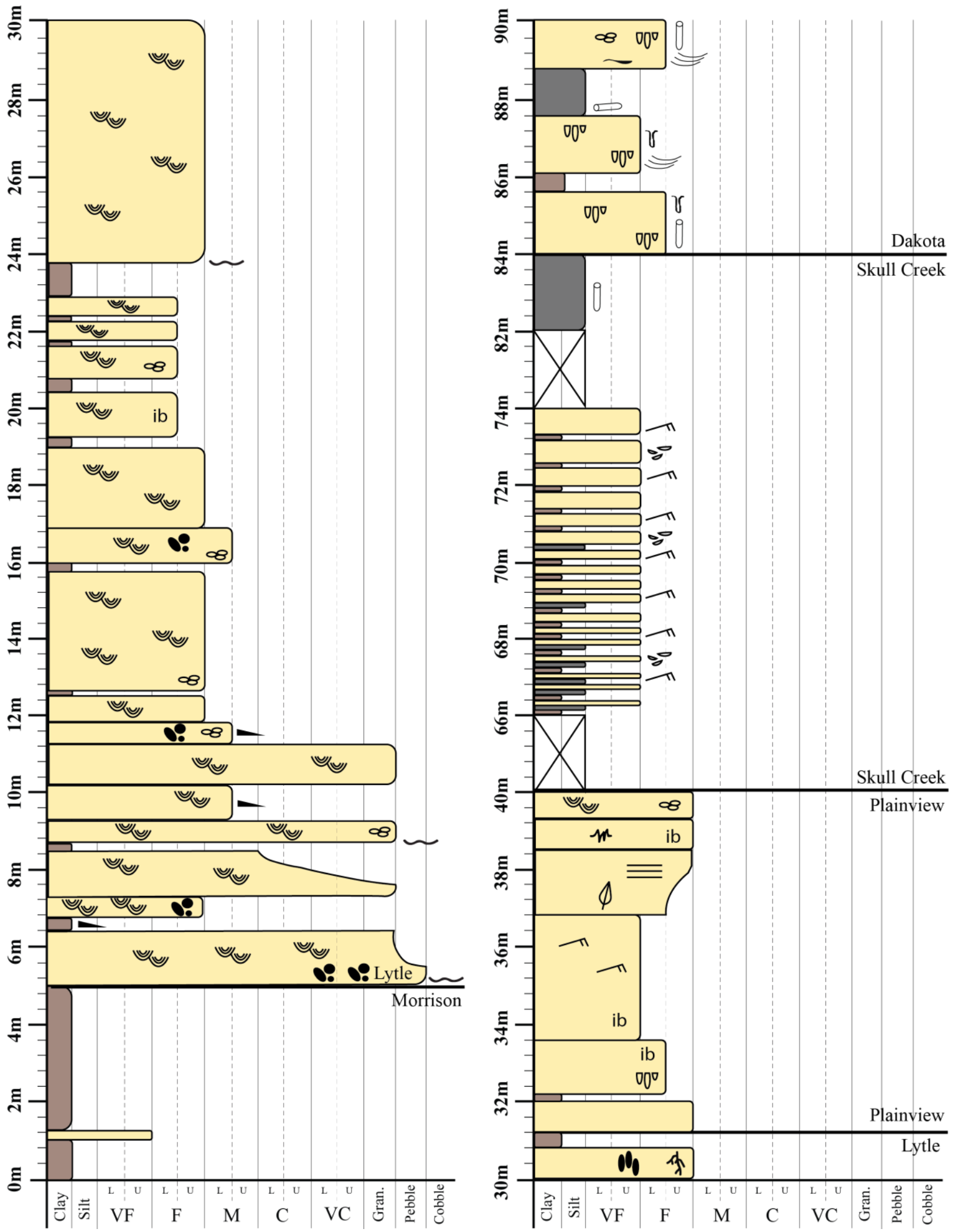

Appendix A2.1: Measured section of Horsetooth Reservoir Spring Canyon Dam (1 of 2). 


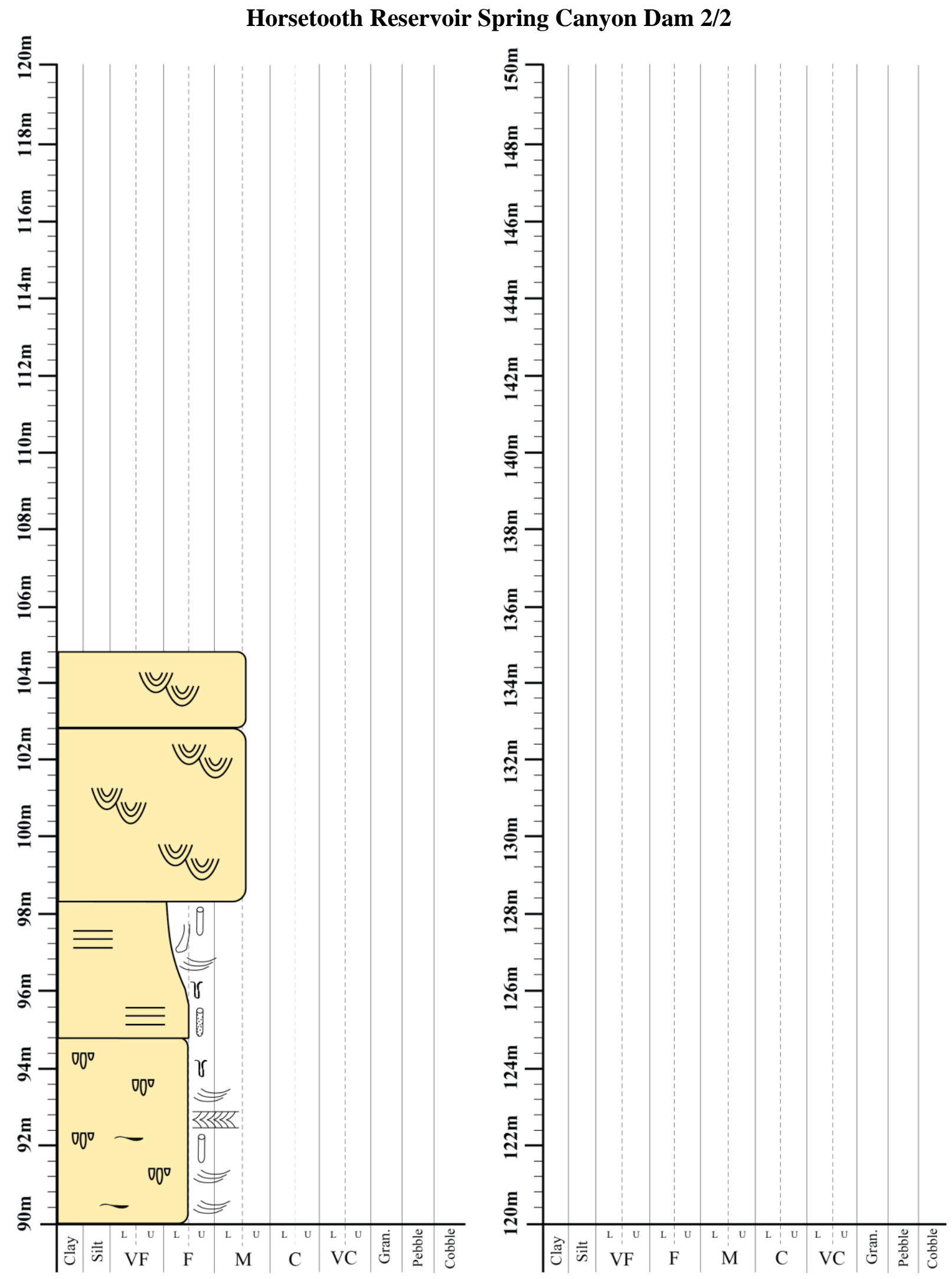

Appendix A2.2: Measured section of Horsetooth Reservoir Spring Canyon Dam (2 of 2). 


\section{I-70 North Side 1/3}
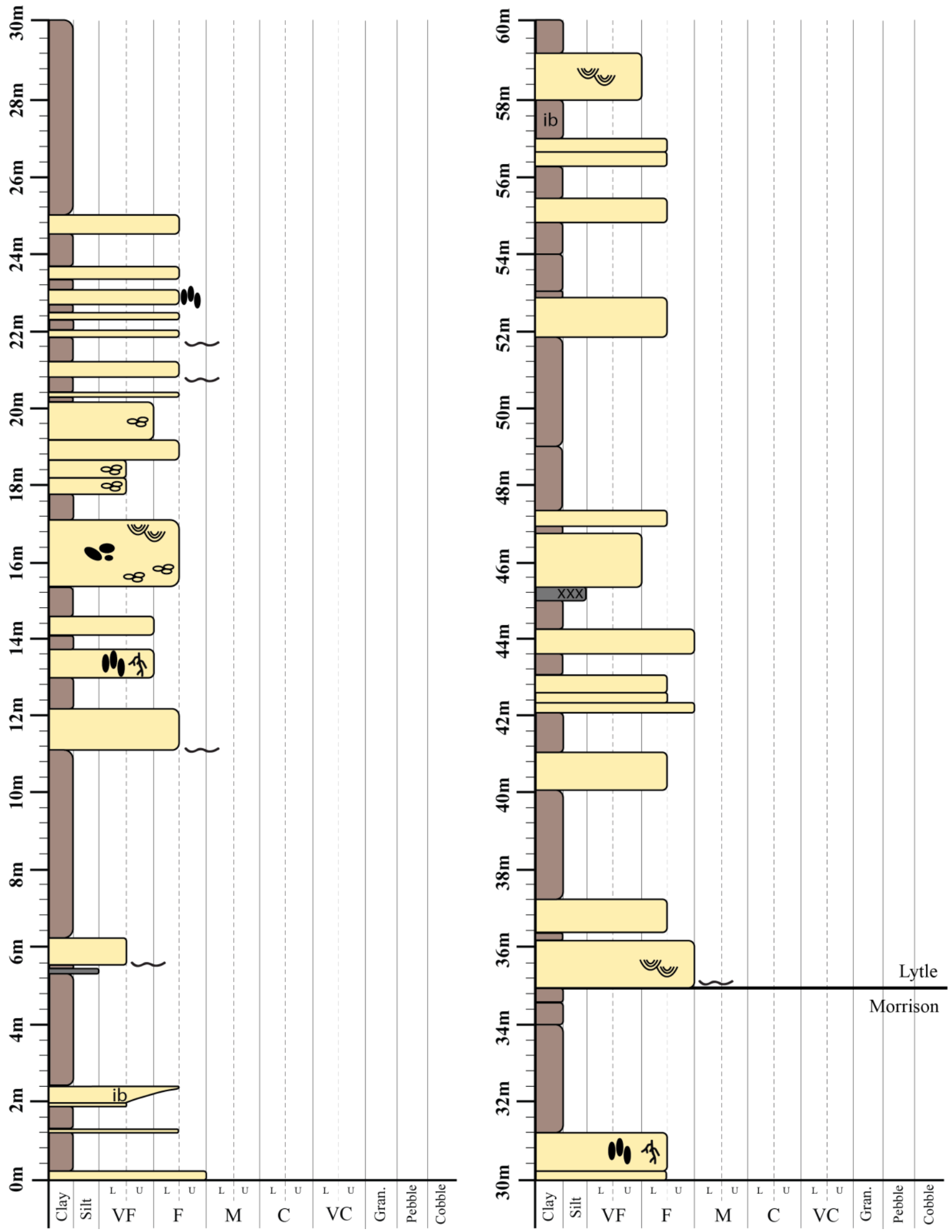

Appendix A3.1: Measured section of I-70 through the Dakota hogback on the north side (1 of 3). 


\section{I-70 North Side 2/3}
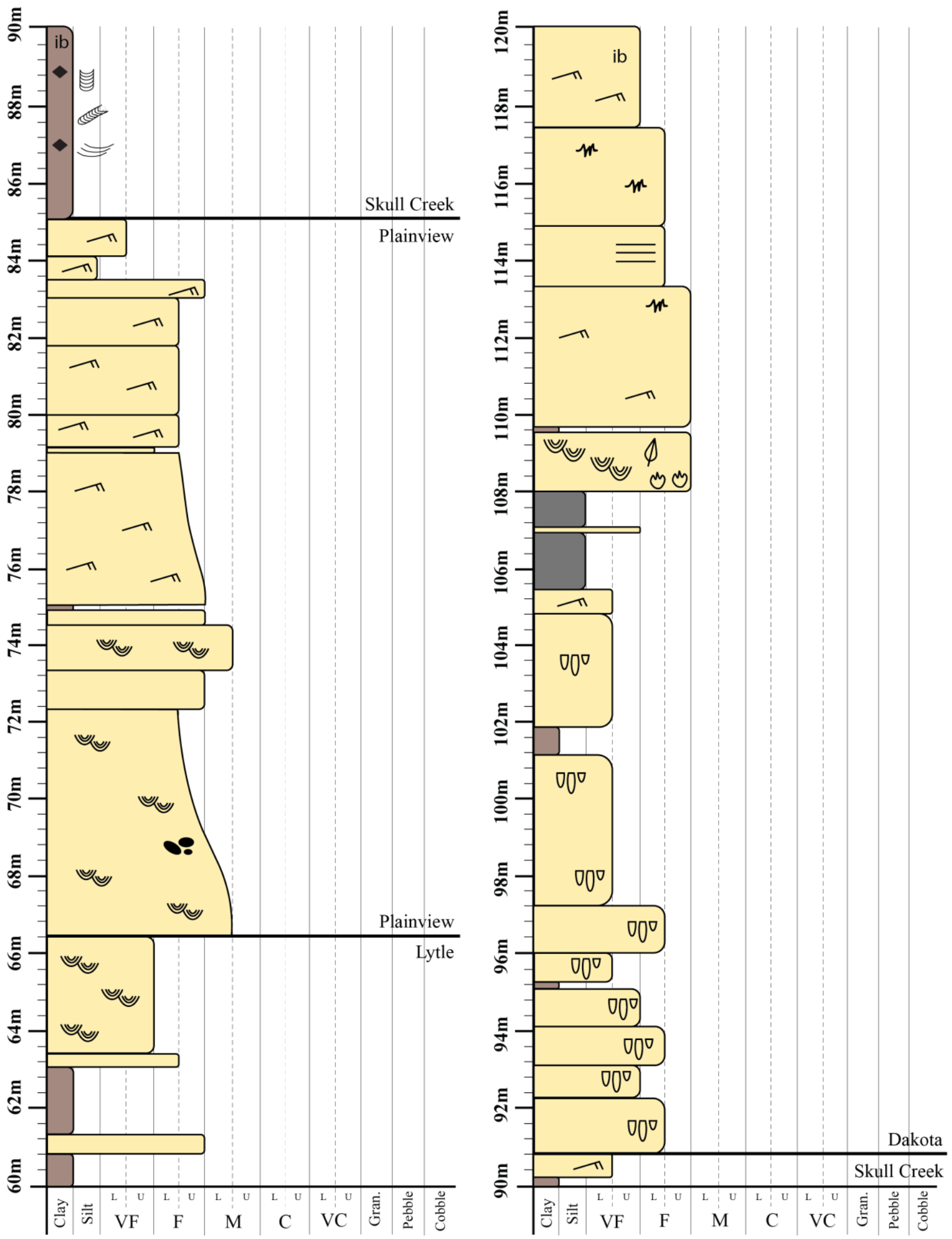

Appendix A3.2: Measured section of I-70 through the Dakota hogback on the north side (2 of 3). 


\section{I-70 North Side 3/3}
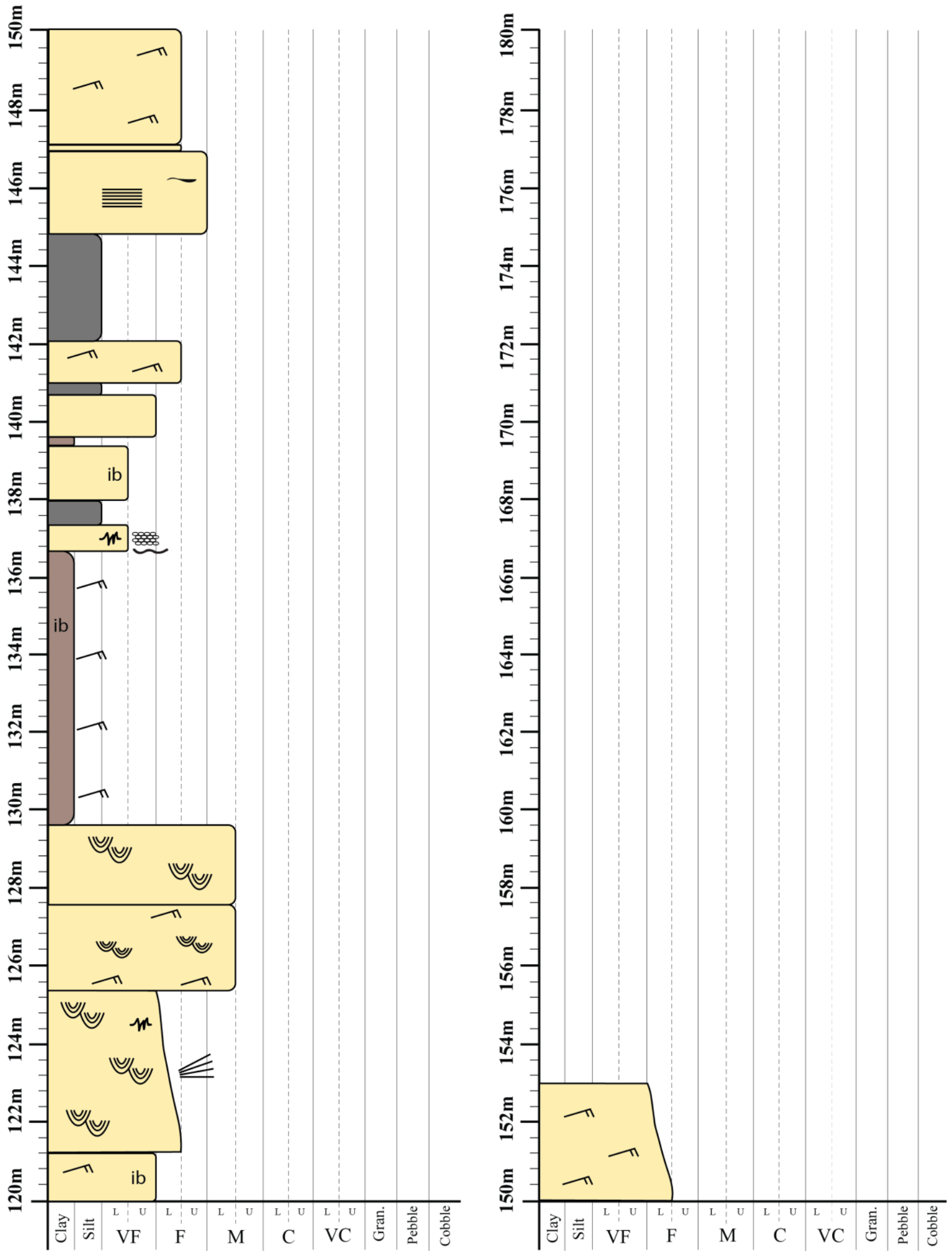

Appendix A3.3: Measured section of I-70 through the Dakota hogback on the north side (3 of 3). 


\section{I-70 South Side 1/4}
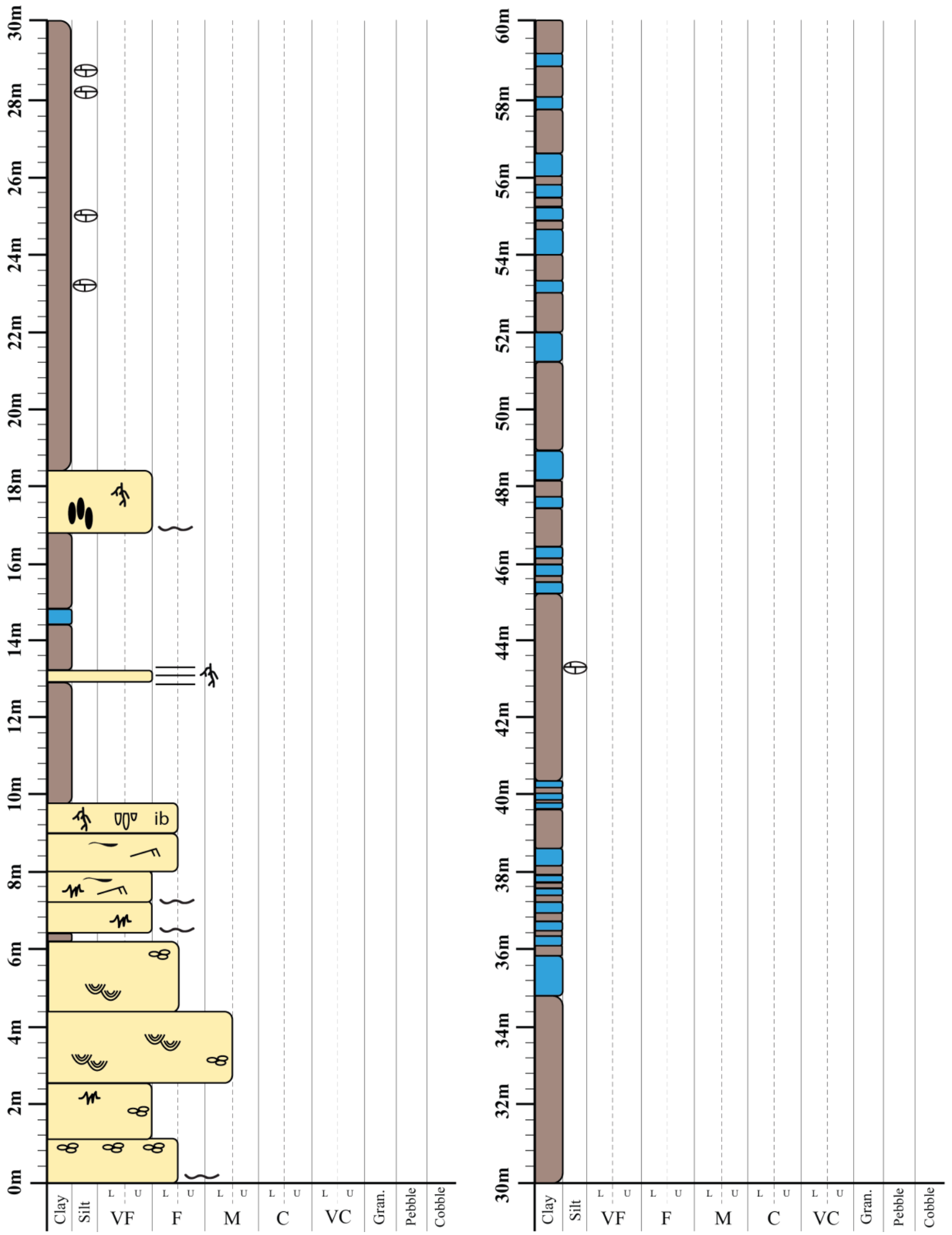

Appendix A4.1: Measured section of I-70 through the Dakota hogback on the south side (1 of 4). 


\section{I-70 South Side 2/4}
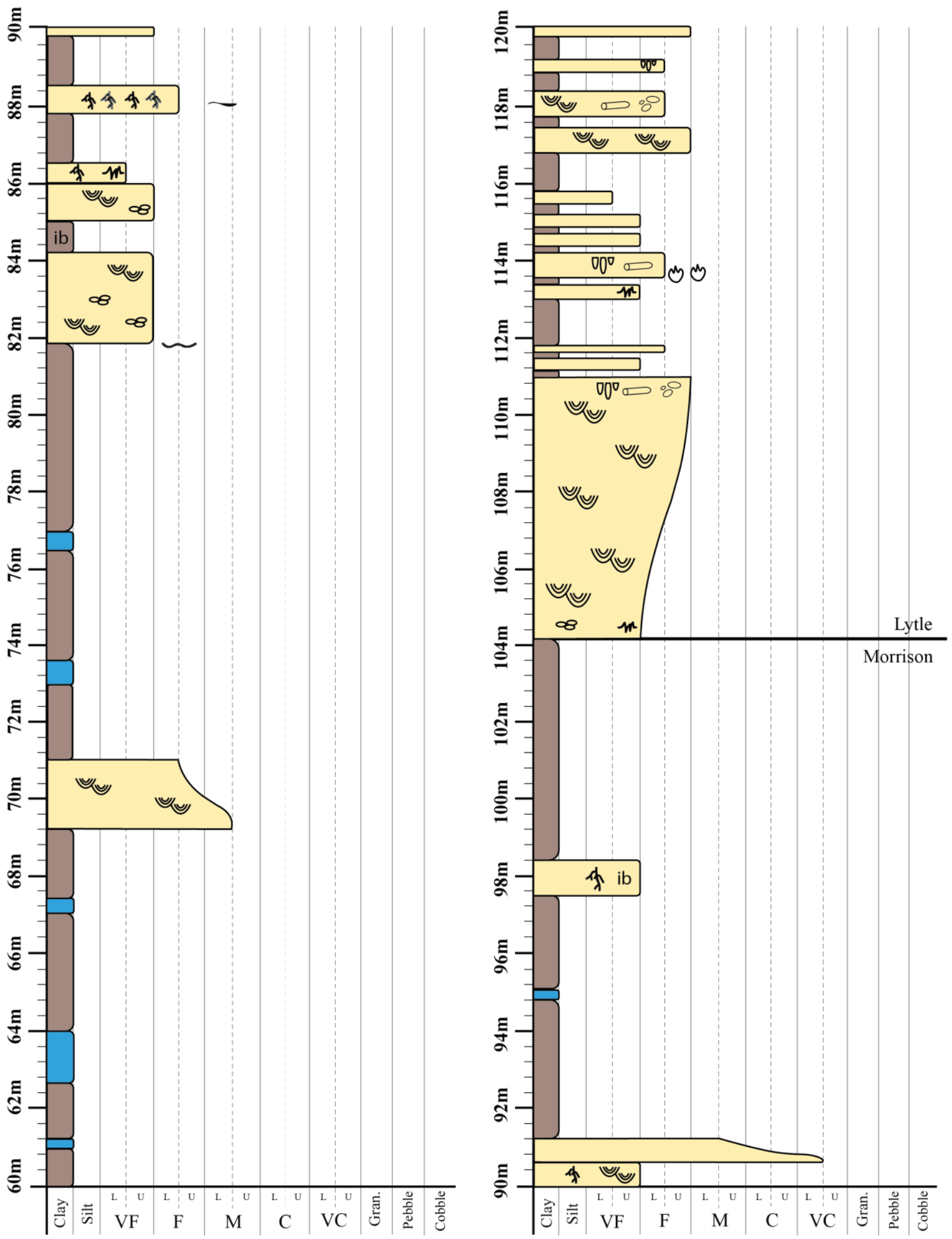

Appendix A4.2: Measured section of I-70 through the Dakota hogback on the south side (2 of 4). 


\section{I-70 South Side 3/4}
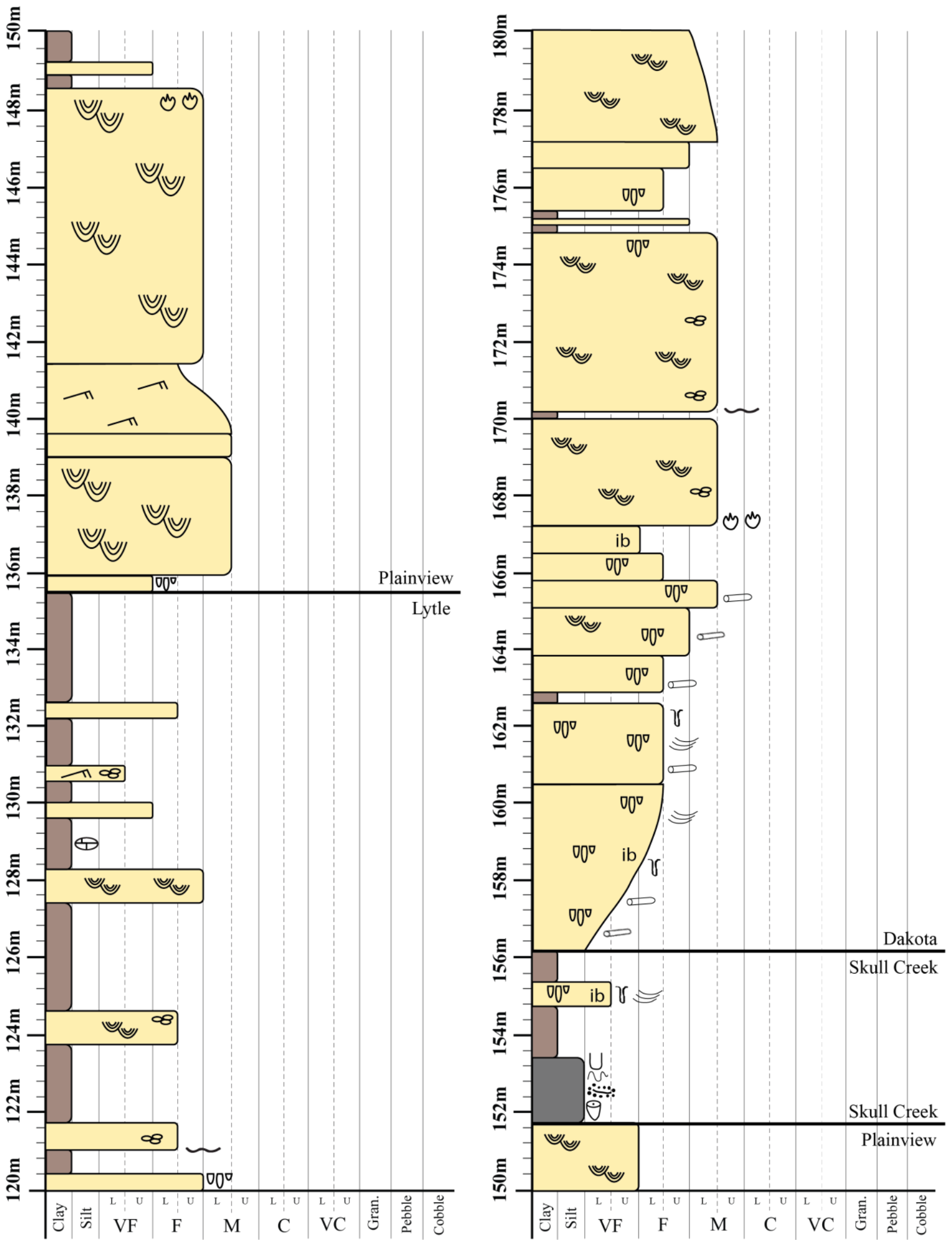

Appendix A4.3: Measured section of I-70 through the Dakota hogback on the south side (3 of 4). 


\section{I-70 South Side 4/4}
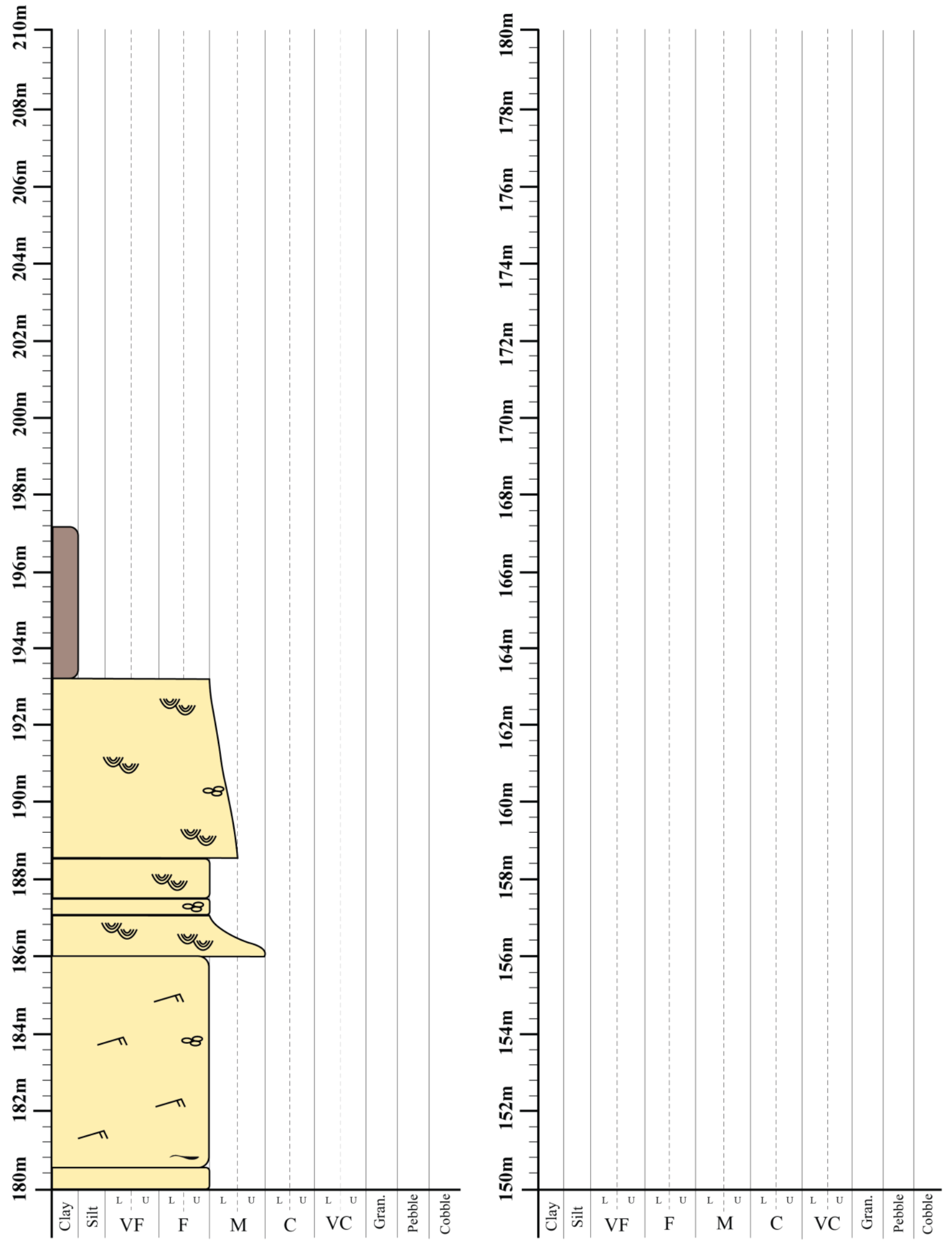

Appendix A4.4: Measured section of I-70 through the Dakota hogback on the south side (4 of 4). 


\section{Dinosaur Ridge 1/2}
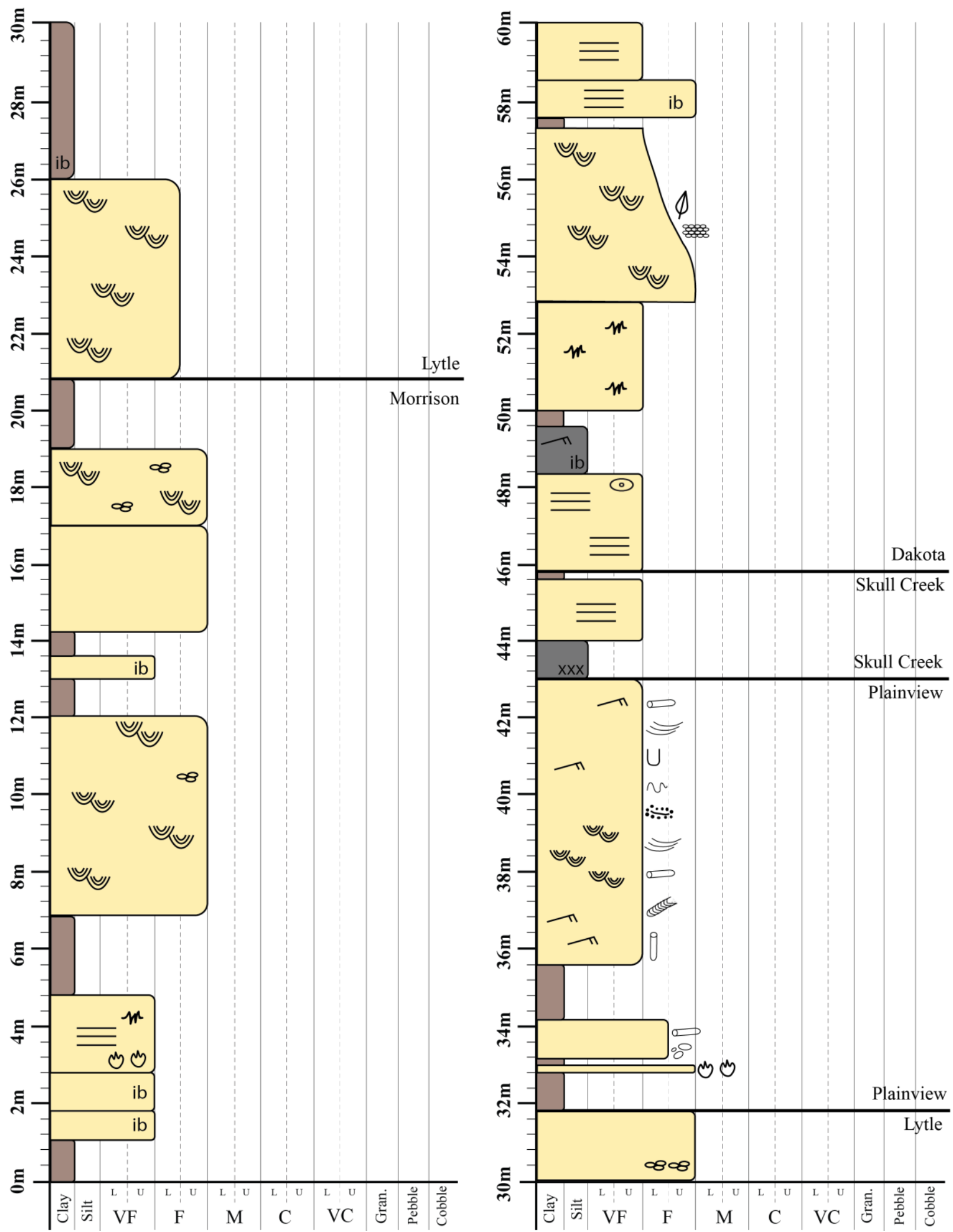

Appendix A5.1: Measured section at Dinosaur Ridge through the Dakota hogback (1 of 2). 


\section{Dinosaur Ridge 2/2}
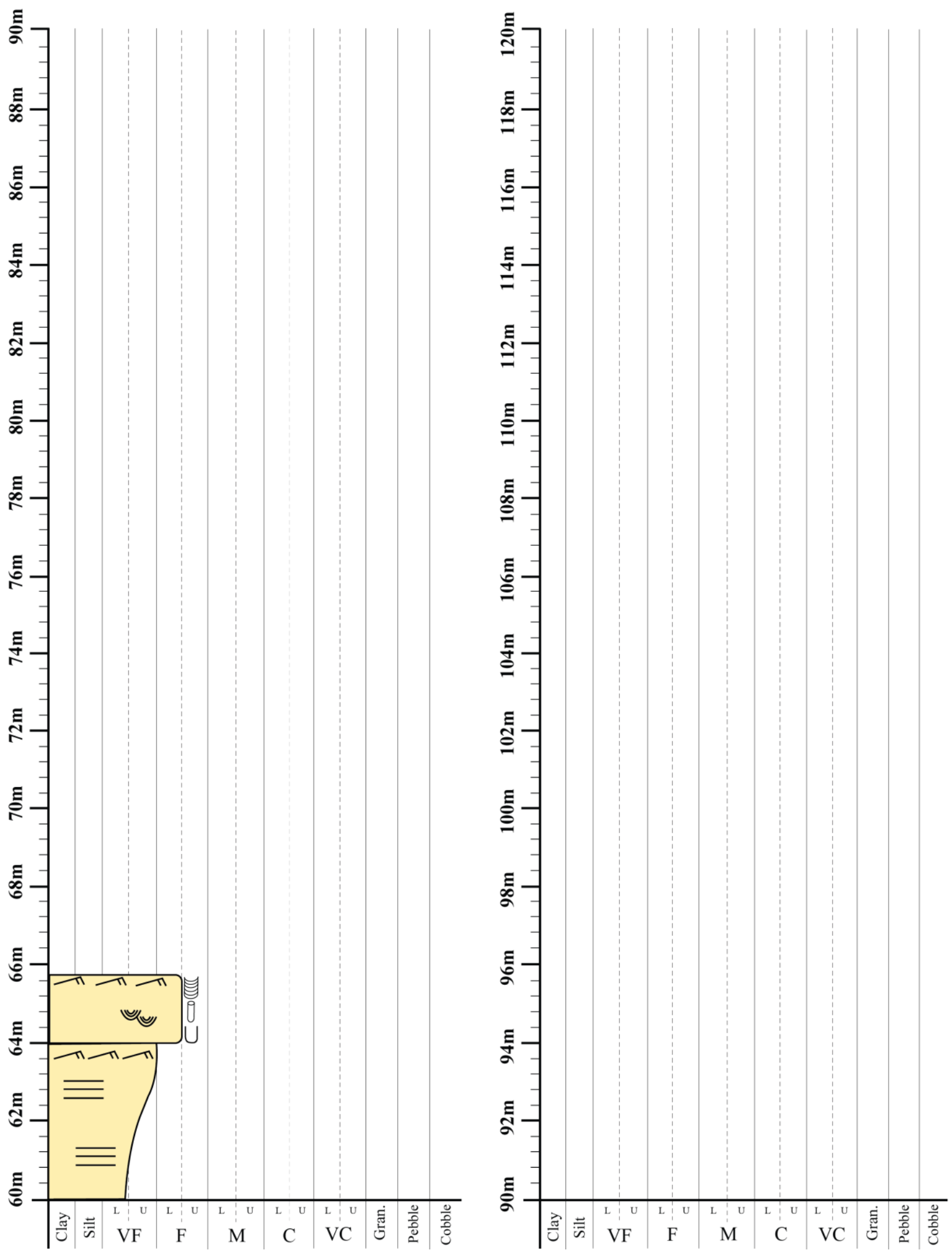

Appendix A5.2: Measured section at Dinosaur Ridge through the Dakota hogback (2 of 2). 
U.S. Highway 285 1/2
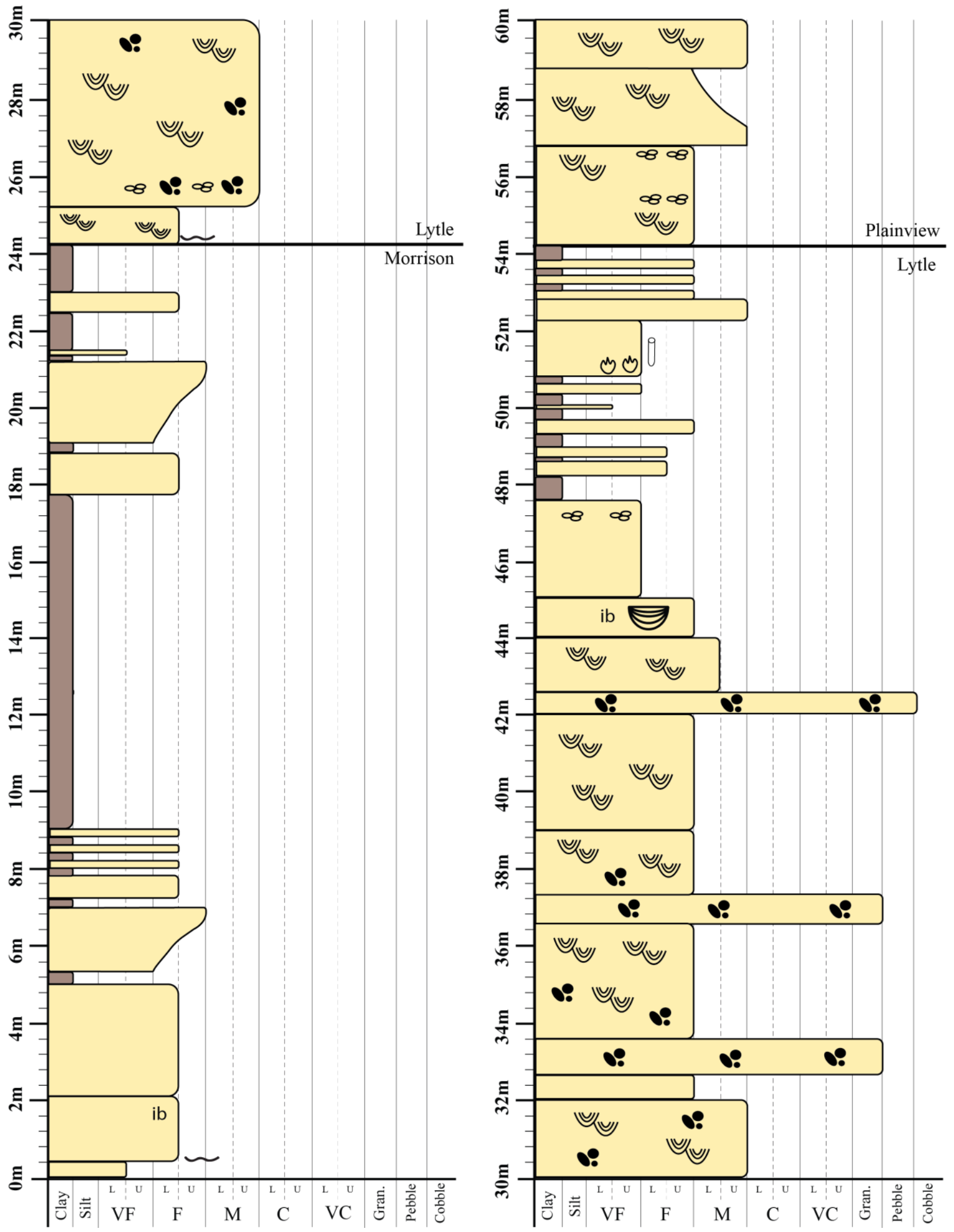

Appendix A6.1: Measured section of U.S. Highway 285 through the Dakota hogback (1 of 2). 
U.S. Highway 285 2/2
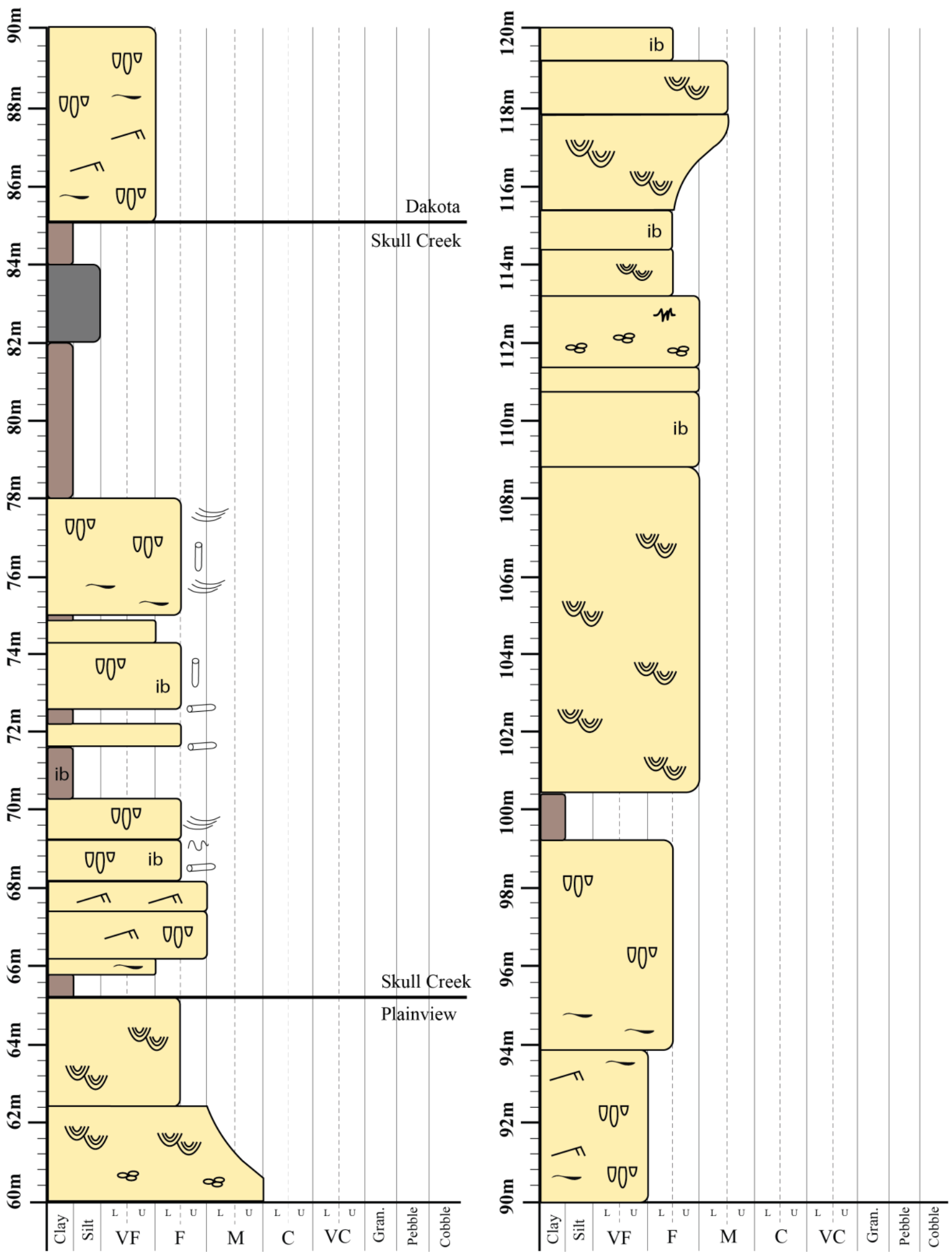

Appendix A6.2: Measured section of U.S. Highway 285 through the Dakota hogback (2 of 2). 


\section{Skyline Drive 1/2}
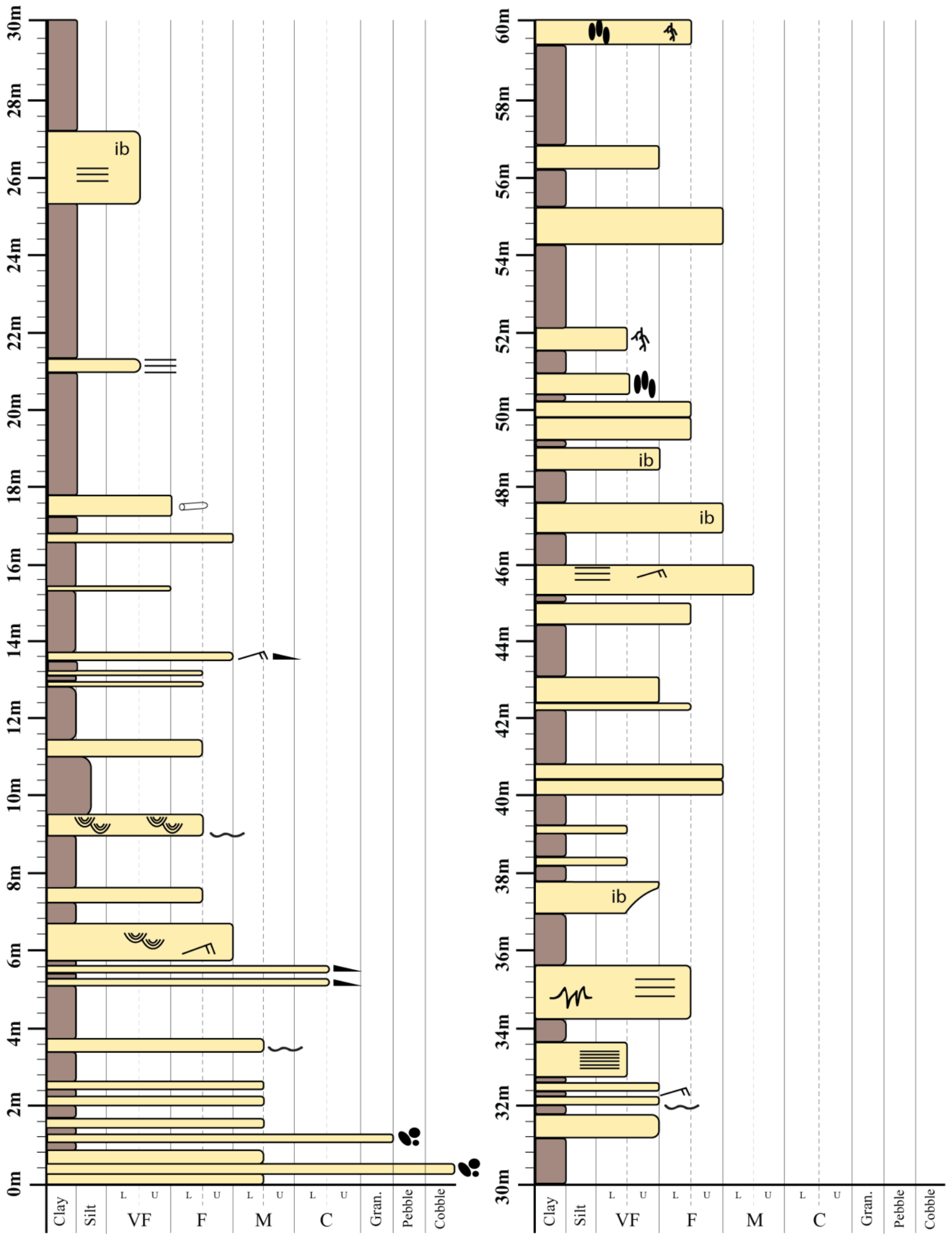

Appendix A7.1: Measured section along Skyline Drive outside Cañon City (1 of 2). 


\section{Skyline Drive 2/2}
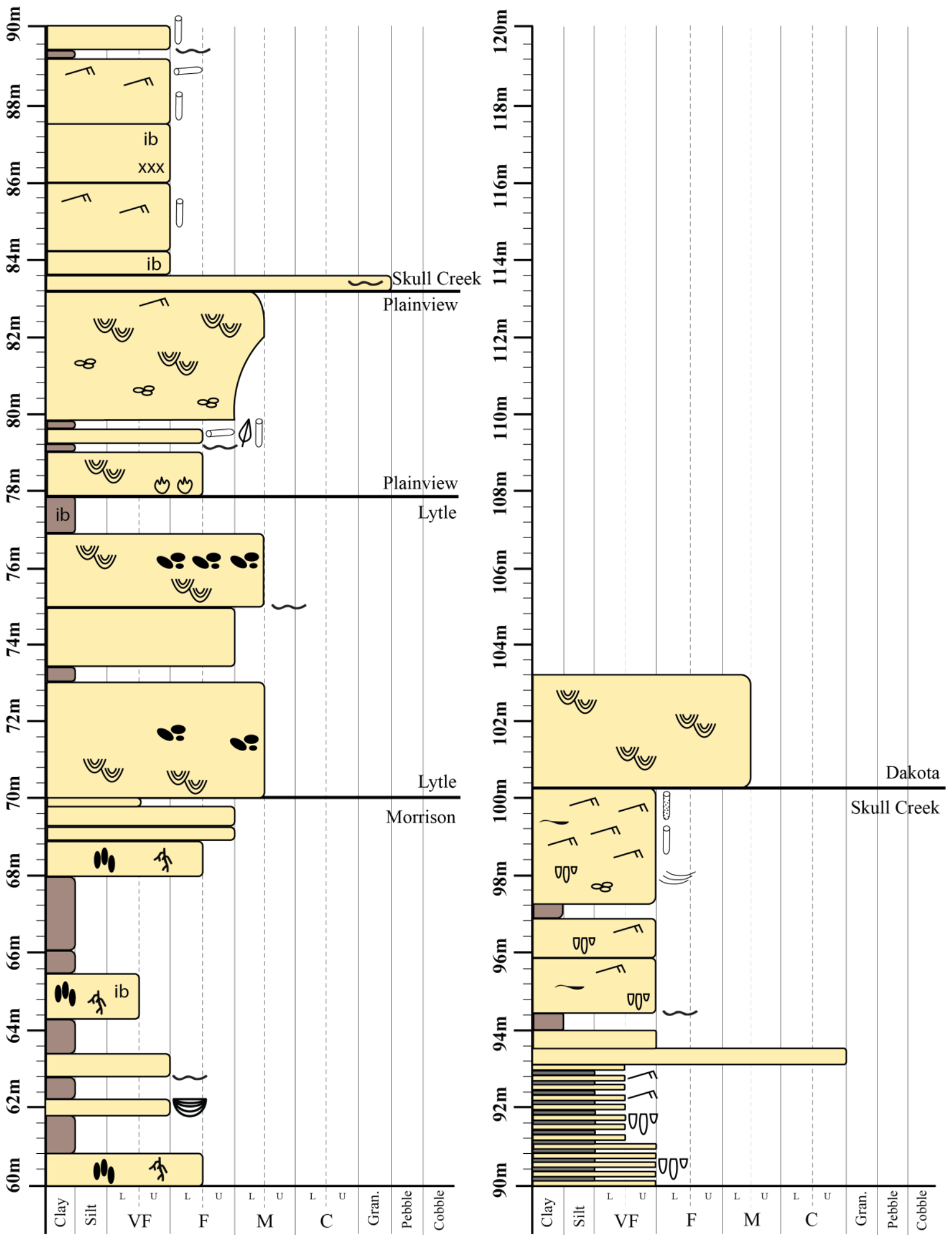

Appendix A7.2: Measured section along Skyline Drive outside Cañon City (2 of 2). 


\section{Appendix B: Arizona Laserchron Center Detrital Zircon Analytical Methods}

Zircon grains are separated from samples using traditional mineral separation methods. Samples first undergo jaw crushing and are fed through a roller mill. Grains are then separated with a Wilfley table to remove low density minerals, undergo hand magnet separation to remove magnetic minerals, Frantz magnetic separation, and methylene-iodide heavy liquid separation to leave behind zircons. A split of these zircons are then mounted for analysis.

Zircon grains are mounted in epoxy and sanded to a depth of $~ 20$ microns, polished, imaged using cathodoluminescence (CL), and cleaned. Each sample's mount consists of 1000 zircon grains, as well as grains from three standards. In this study, three standards were used: SL, R33, and FC. SL is the primary standard used by the ALC and consists of Sri Lanka zircons with a 206 $\mathrm{Pb} / 238 \mathrm{U}$ ID-TIMS age of 563.2 $\pm 4.8 \mathrm{Ma}(2 \sigma)$ (Gehrels et al., 2008). R33 is a secondary standard of small zircons with a $206 \mathrm{~Pb} / 238 \mathrm{U}$ ID-TIMS age of $419.3 \pm 0.4 \mathrm{Ma}(2 \sigma)$ (Black et al., 2004). FC is also a secondary standard consisting of grains from the Duluth Gabbro Complex with a $206 \mathrm{~Pb} / 238 \mathrm{U}$ ID-TIMS age of $1099.0 \pm 0.5 \mathrm{Ma}(2 \sigma)$ (Paces and Miller 1993). The CL images are used to place spots on zircon grains at random to avoid bias, in addition to spots on the three standards. Once spots are placed, the spots and a spot sequence are imported into the laser's computer.

Laser Ablation Multicollector Inductively Coupled Plasma Mass Spectrometry (LA-MCICPMS) involves ablating grains with a Photon Machines Analyte G2 excimer laser, first with 40 $\mu \mathrm{m}$ diameter cleaning shots followed by $20 \mu \mathrm{m}$ diameter analytical shots, to a depth of $\sim 15 \mu \mathrm{m}$. Ablated material is transported via helium to the plasma source of the Nu HR ICPMS, which then measures $\mathrm{U}, \mathrm{Th}, \mathrm{Pb}$, and $\mathrm{Hg}$ isotopes simultaneously in static mode. Faraday detectors with 
$3 \times 1011 \mathrm{ohm}$ resistors measures $238 \mathrm{U}, 235 \mathrm{U}, 232 \mathrm{Th}, 208 \mathrm{~Pb},{ }_{207} \mathrm{~Pb}$, and $206 \mathrm{~Pb}$, while discrete dynode ion counters measures $204 \mathrm{~Pb}$ and $202 \mathrm{Hg}$. 


\section{Appendix C: Detrital zircon U-Pb datasets}

The high-quality $\mathrm{DZ} \mathrm{U}-\mathrm{Pb}$ datasets described herein will be made available to the research community through geochron.org. 
Appendix D: DZMix model results

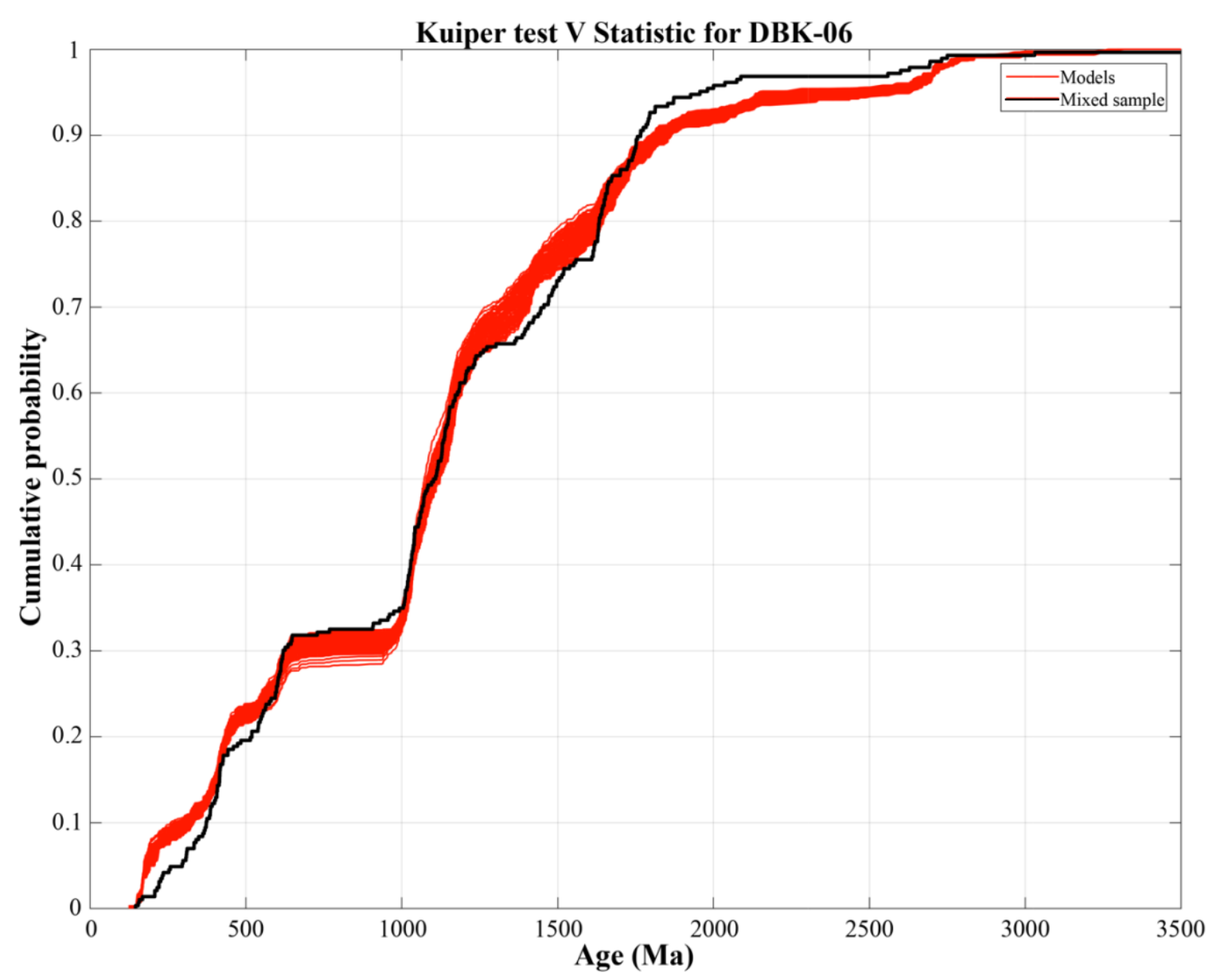

Appendix D1: Model results using the Kuiper test V statistic for DBK-06 plotted as a cumulative distribution function. 


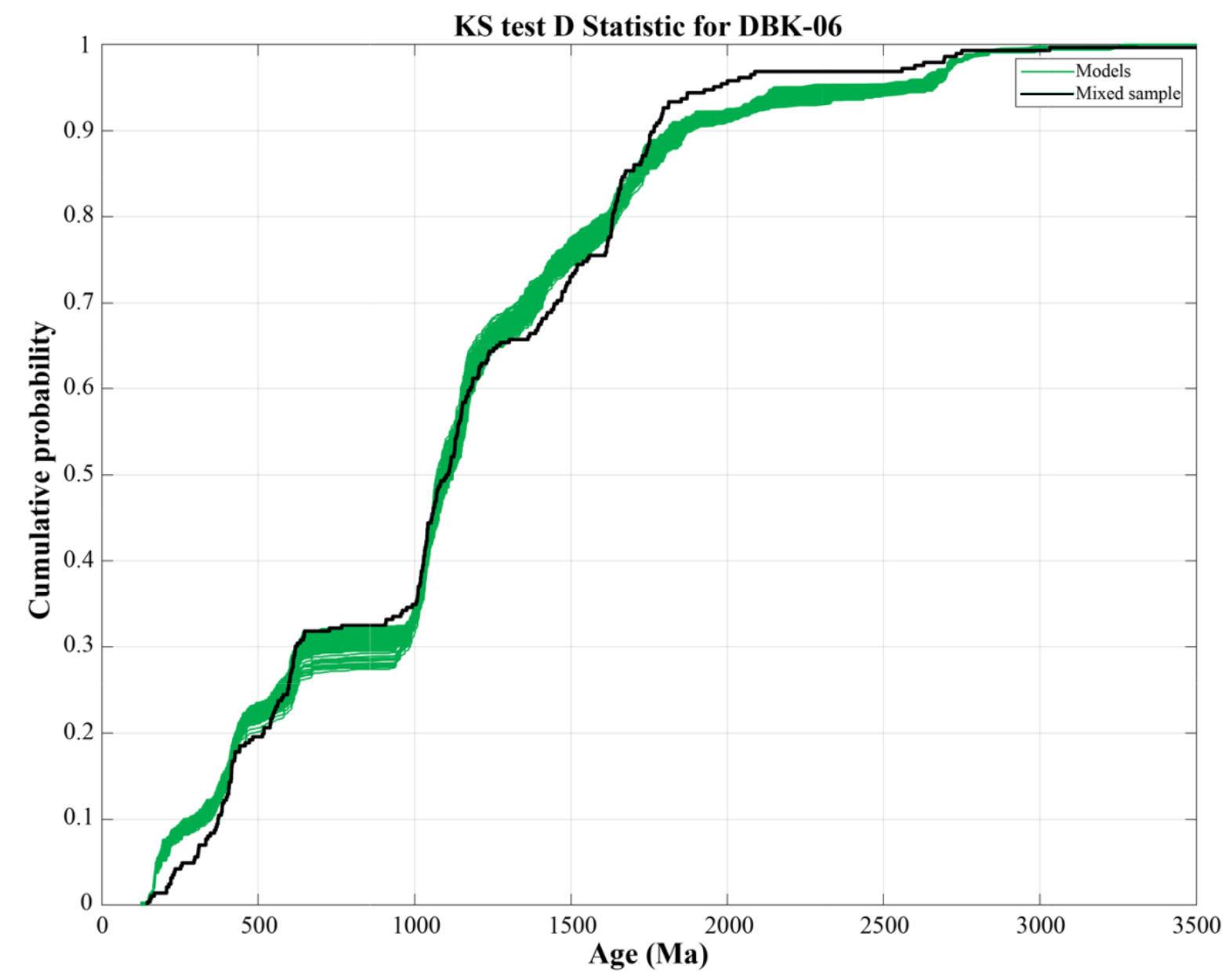

Appendix D2: Model results using the Komolgorov-Smirnov test D statistic for DBK-06 plotted as a cumulative distribution function. 


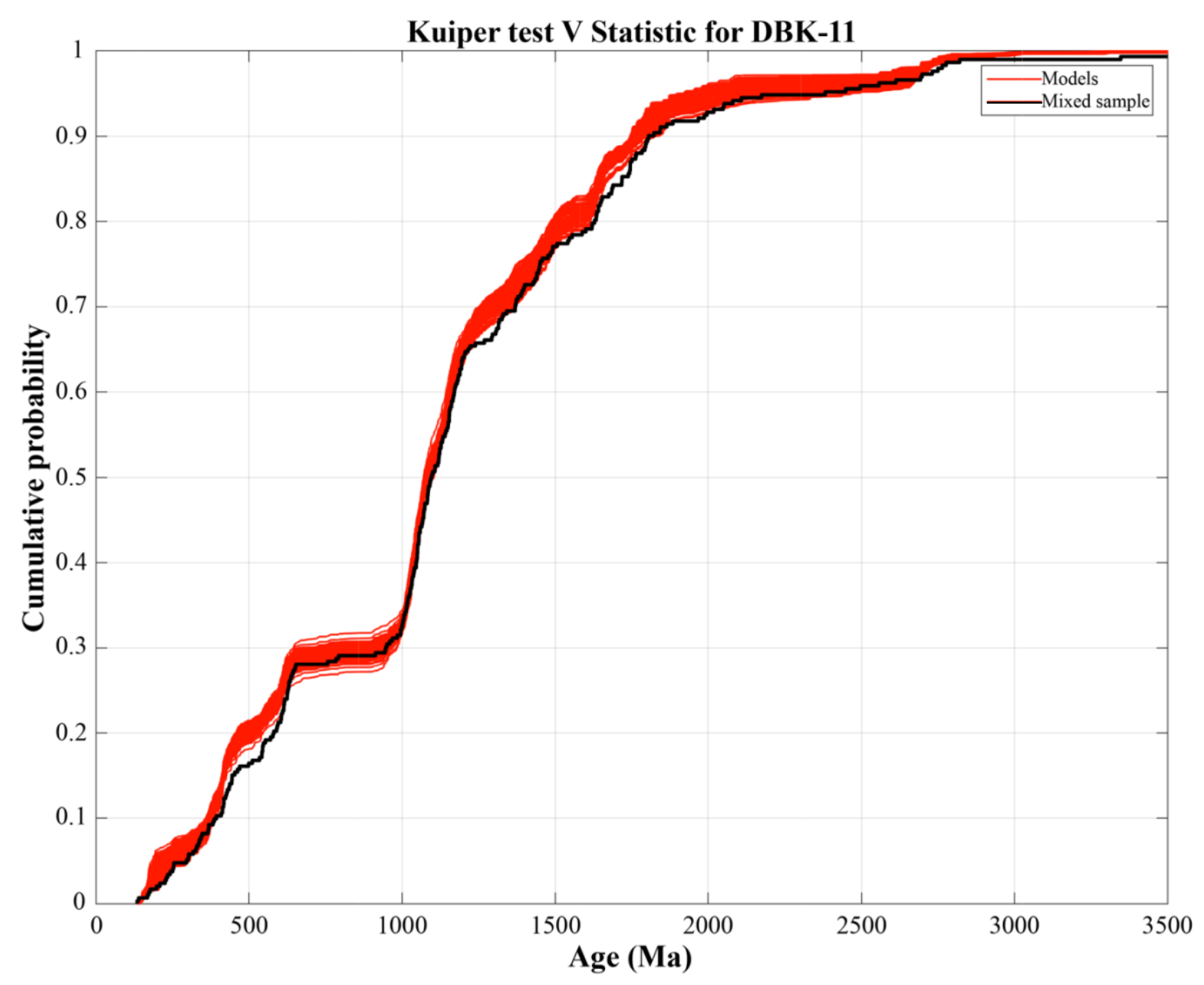

Appendix D3: Model results using the Kuiper test V statistic for DBK-11 plotted as a cumulative distribution function. 


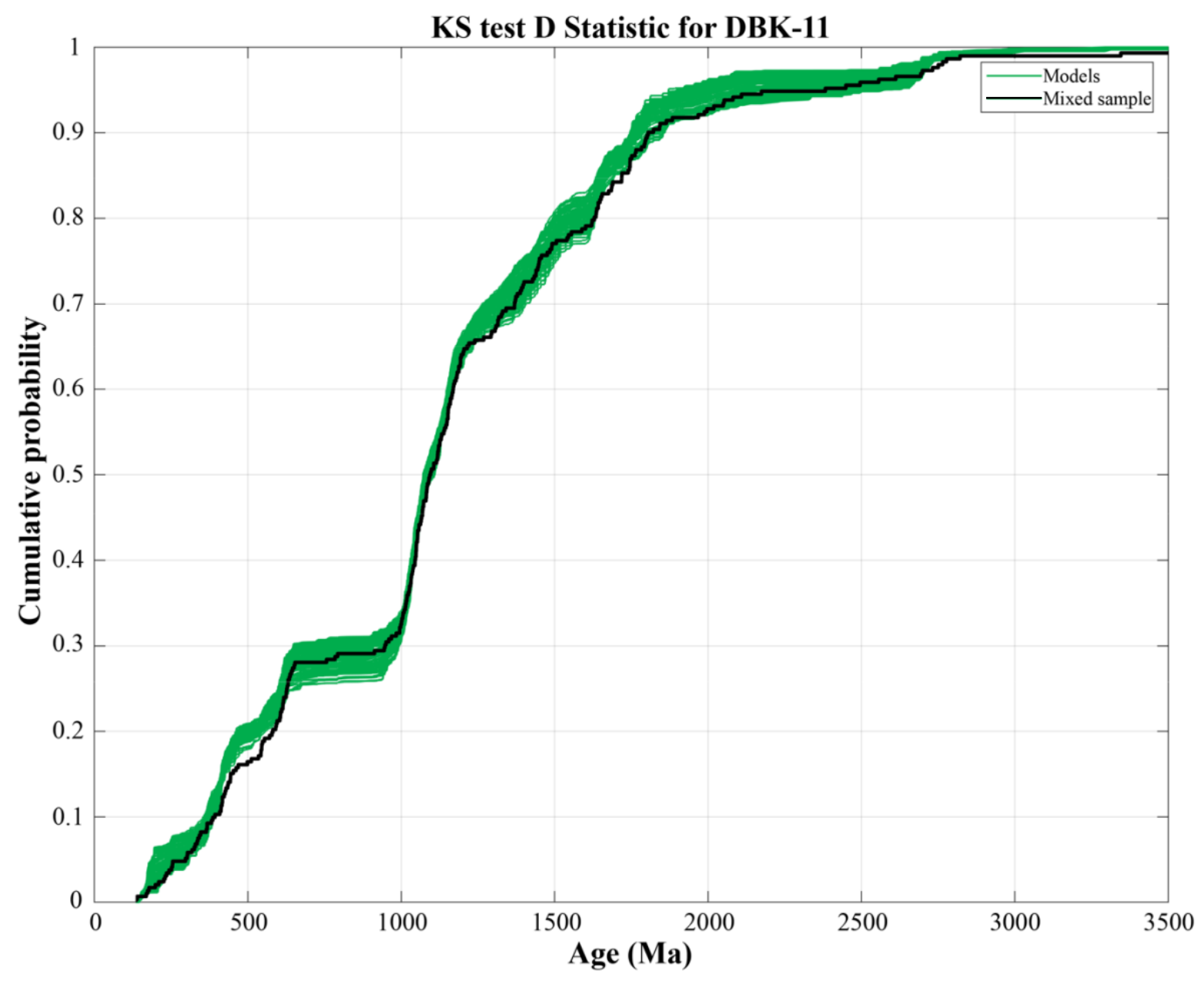

Appendix D4: Model results using the Komolgorov-Smirnov test D statistic for DBK-11 plotted as a cumulative distribution function. 